\title{
Income Distribution and the Business Cycle
}

\section{Mostafa Shahee}

\author{
Submitted to the \\ Institute of Graduate Studies and Research \\ in partial fulfillment of the requirements for the Degree of
}

\author{
Doctor of Philosophy \\ in \\ Economics
}

\author{
Eastern Mediterranean University \\ September 2014 \\ Gazimağusa, North Cyprus
}


Approval of the Institute of Graduate Studies and Research

Prof. Dr. Elvan Y1lmaz

Director

I certify that this thesis satisfies the requirements as a thesis for the degree of Doctor of Philosophy in Economics.

Prof. Dr. Mehmet Balcilar

Chair, Department of Economics

We certify that we have read this thesis and that in our opinion it is fully adequate in scope and quality as a thesis for the degree of Doctor of Philosophy in Economics

Prof. Dr. Mehmet Balcilar

Supervisor

1. Prof. Dr. Mehmet Balcilar

2. Prof. Dr. Glenn P. Jenkins

3. Prof. Dr. Hakan Yetkiner

4. Prof. Dr. Zeynel A. Ozdemir

5. Assoc. Prof. Dr. Sevin K. Ugural 


\begin{abstract}
This thesis consists of six chapters. The first chapter is devoted to the introduction to explore how the income distribution within the countries has become a prominent issue in policy making over time. In the second chapter, the related literature on income distribution, GDP and the relationship between these two variables is reviewed. The methodology used for dating the business cycles is extensively explained in the third chapter. The remaining chapters constitute three self-contained essays. The investigation of a possible relationship between the degree of income equality within the countries, and the severity of recession and expansion phase of business cycles, is examined using two different methods. To carry out the investigation reported in chapters four, five and six we use data collected for 40 years on Gini index values and the GDPs of 36 selected countries.
\end{abstract}

The main goal in the first essay is to determine how the deepness and duration of cycles of GDP is correlated with the Gini index values of countries and whether this relationship is mainly sourced from consumption or investment. Likewise, an investigation is carried out to determine if the number of cycles in consumption, investment and GDP of countries could be associated with the level of income inequality in those countries. The results of the correlation and the t-test analysis indicates that income inequality leads to a deeper and longer decline of GDP, which causes a greater cumulative income loss of GDP during a recession period, and a somewhat faster speed of recovery during an expansion period. In addition, the result of a correlation between Gini index values and the number of cycles in consumption, investment and GDP indicate that income inequality is associated with a greater 
number of cycles in consumption and GDP and a lower number of cycles in investment.

In the second essay, the relationship between income equality and the recession is theoretically examined. Models are presented to show how the movement of four components of GDP as consumption, investment, government spending and net export takes place during a recession period for the countries with different level of income distribution. This shows that the countries with a more equality of income distribution would experience a less costly recession. For empirical analysis the instrumental variable is employed in which the findings of empirical analysis support the theoretical arguments. In the third essay, an instrumental variable analysis is employed to find a possible relationship between income inequality and the intensity of expansionary phase of cycles. Although the signs of the coefficients indicate that a more equal income distribution is associated with a somewhat faster recovery, the results are not statistically significant.

Keywords: Income Distribution, Business Cycle, Recession, Expansion, Instrumental Variable, Cumulative Loss and Amplitude 


\section{$\ddot{O Z Z}$}

Bu tez altı üniteden oluşmaktadır. Ülkeler içinde gelir dağılımının zamanla politika geliştirmede nasıl öne çıkan bir mesele olduğunu araştırmak için birinci bölüm girişe ayrılmıştır. İrdelenecek problemi tanımlamak ve analizimize sağlam bir temel oluşturmak için ikinci bölümde gelir dağılımı, gayri safi yurtiçi hasıla (GSYİH) ve bu iki değişken arası ilişki üzerine ilgili literatür (alanyazın) taranmıştır. Üçüncü bölümde iktisadi dalgalanmaları belirlemek için kullanılan metodoloji kapsamlı bir şekilde açıklanmıştır. Geri kalan dört, beş ve altıncı bölümler bağımsız üç makaleden oluşmaktadır. İki farklı yöntem kullanarak bir yanda ülkeler içinde gelir eşitliği diğer yanda iktisadi dalgalanmaların resesyon (durgunluk) ve büyüme safhalarının şiddeti arasındaki olası ilişki incelenmiştir. Bölüm dört, beş ve altıda açıklanan incelemeyi yürütmek için seçilmiş 36 ülkenin Gini katsayıları ve GSYİH'ları üzerine toplanan 40 yıllık veri kullanılmıştır.

Birinci makalede esas amaç GSYİH dalgalanmalarının derinliği ve süresinin ülkelerin Gini katsayıları ile nasıl ilişkili olduğunu ve bu ilişkinin esas olarak tüketimden ya da yatırımdan kaynaklandığını belirlemektir. Aynı şekilde, ülkelerin tüketim, yatırım ve GSYİH'larındaki dalgalanma sayısının bu ülkelerdeki gelir eşitsizliği düzeyi ile bağlantılı olup olmadığını belirlemek için bir araştırma yürütülmüştür. Korelasyon ve t-testi analiz sonuçları göstermektedir ki gelir eşitsizliği GSYİH’nın daha derin ve uzun süreliğine düşmesine neden olmaktadır, ki bu da GSYİH'da daha büyük bir resesyon süresince kümülatif gelir kaybına (CTS), ve kısmen daha yüksek bir büyüme süresince iyileşme hızına (ETS) sebep olmaktadır. Ek olarak, Gini katsayıları ve tüketim, yatırım ve GSYİH dalgalanma 
sayısı arasındaki bir ilişki sonucu göstermektedir ki gelir eşitsizliği tüketim ve GSYİH'da daha büyük bir dalgalanma sayısı ve yatırımda daha düşük bir dalgalanma sayısı ile ilişkilidir.

İkinci makalede gelir eşitsizliği ile resesyon arasındaki ilişki teorik olarak incelenmiştir. GSYİH'nın dört unsuru olan tüketim, yatırım, devlet harcamaları ve net ihracat hareketinin farklı gelir dağılımı olan ülkelerde resesyon süresince nasıl yer aldığını gösteren modeller sunulmuştur. Bu göstermektedir ki gelir dağılımının daha eşit olduğu ülkeler daha düşük maliyetli bir resesyon yaşayacaklardır. Bir enstrümantal değişken analizi yapılmıştır. Ampirik analiz sonuçları teorik tartışmalarla gelir eşitsizliği ve resesyon şiddeti arasındaki ilişkiyi konu alan birinci makalenin sonuçlarını desteklemektedir. Son olarak, üçüncü makalede gelir eşitsizliği ve genişlemeci dalgalanma safhasının yoğunluğu arasındaki olası bir ilişkiyi bulmak için bir enstrümantal değişken analizi kullanılmıştır. Katsayıların işaretleri daha eşit bir gelir dağılımının kısmen daha hızlı bir iyileşme ile ilişkili olduğunu göstermesine rağmen, sonuçlar istatistiksel olarak anlamlı değildir. 
Dedicated to My Parents for Their Continuous Supports 


\section{ACKNOWLEDGMENT}

Foremost, I would like to express my sincere gratitude to my advisor Prof. Glenn Paul Jenkins for his insightful comments, his patience, motivation, enthusiasm, immense knowledge and his continuous support of my $\mathrm{PhD}$ study and research. His far-reaching knowledge and experience has immensely guided me during the completion of my graduate programs, master and $\mathrm{PhD}$, as well as my research tasks. His contribution to my professional life is certainly enormous. Besides Prof. Jenkins, I would like to thank Prof. Mehmet Balcilar whose support during the completion of this thesis was certainly prominent. Also, my great gratitude goes to Prof. Sevin Ugural for her kind advice and supports as well as her great knowledge and attitudes towards teaching, that I had the chance to take advantage of it, during my $\mathrm{PhD}$ program. In addition, my deep appreciation goes to Prof. Serhan Ciftcioglu for sharing his great knowledge with me during the completion of this thesis. Last but not least, my sincere gratitude goes to the external members of examining committee, Prof. Hakan Yetkiner, Prof. Zeynel A. Ozdemir. 


\section{TABLE OF CONTENTS}

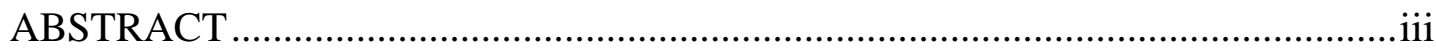

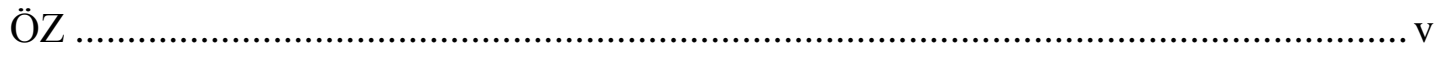

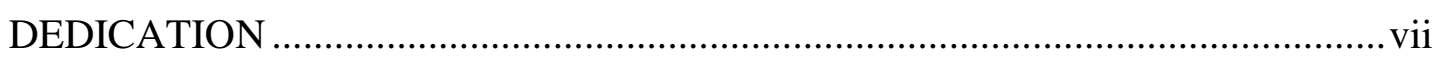

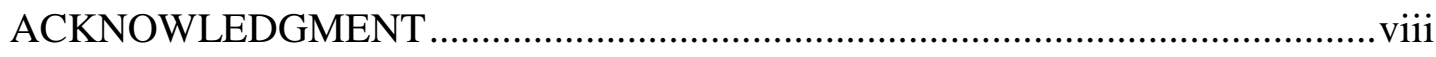

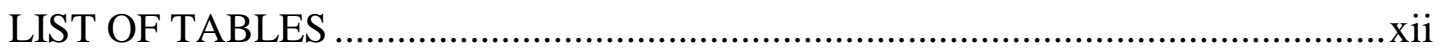

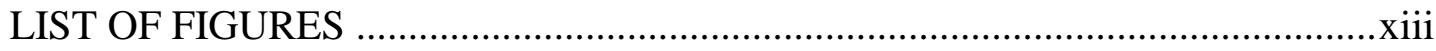

LIST OF ABBREVIATIONS ......................................................................

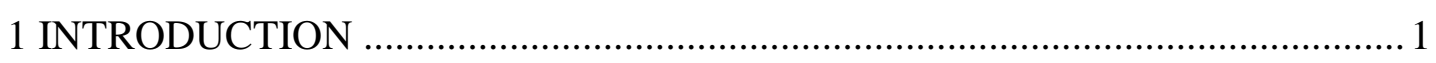

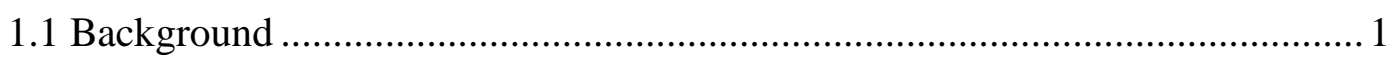

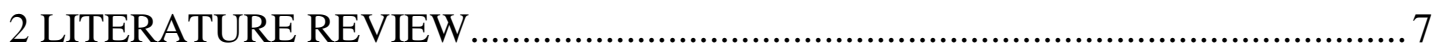

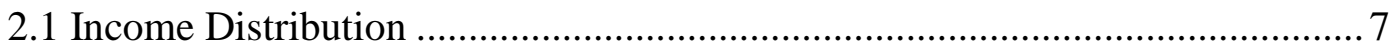

2.1.1 Overviews of Income Distribution ..................................................... 7

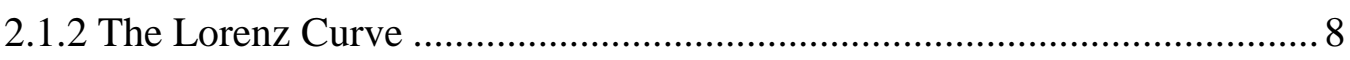

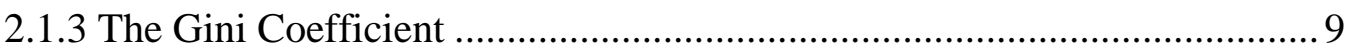

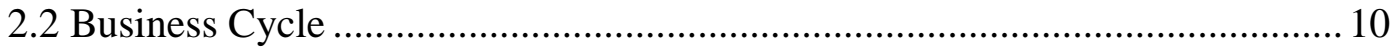

2.3 Income Inequality, GDP Growth and Business Cycle ................................ 13

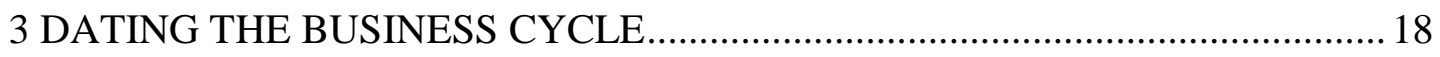

4 INCOME DISTRIBUTION AND THE BUSINESS CYCLE ............................. 22

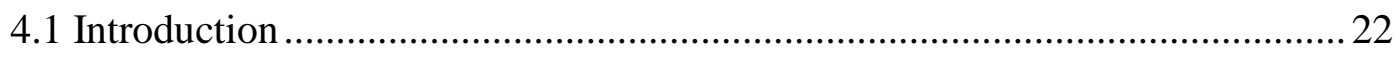

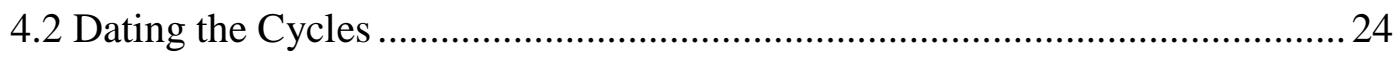

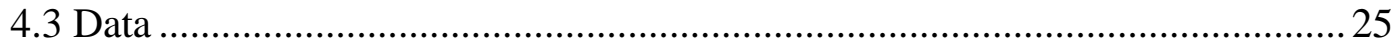

4.4 Empirical Approach and Related Arguments ........................................... 26 
4.4.1 Coefficients of Investment and Consumption........................................26

4.4.2 Income Inequality and GDP, Investment and Consumption....................28

4.4.3 Income Distribution and the Number of Business Cycles ........................ 33

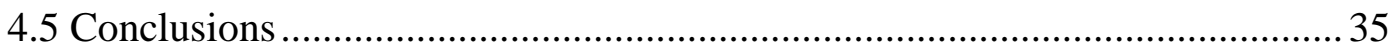

5 INCOME DISTRIBUTION AND RECESSIONS …........................................... 36

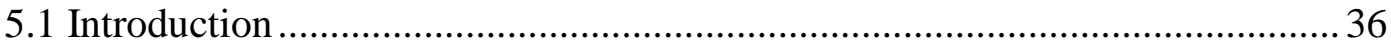

5.2 The Relationship between the Movement of the Components of Aggregate

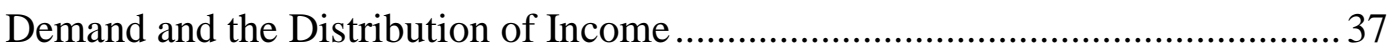

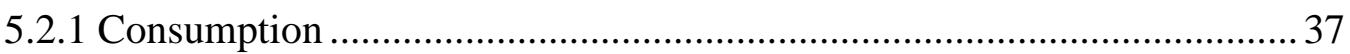

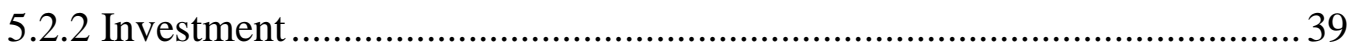

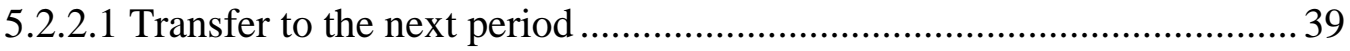

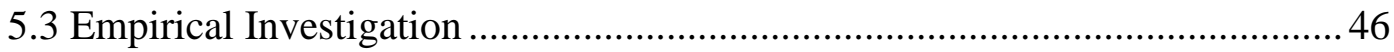

5.3.1 Data Employed and the Cycle Dating Approach ..................................... 47

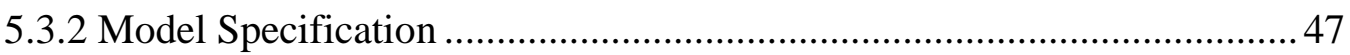

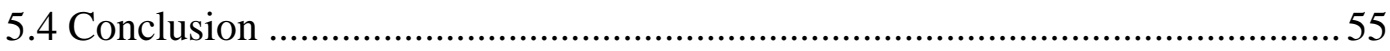

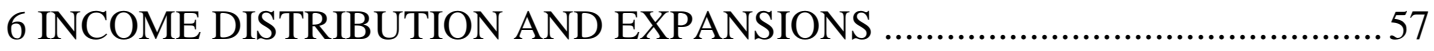

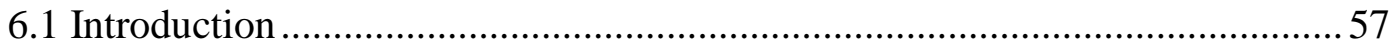

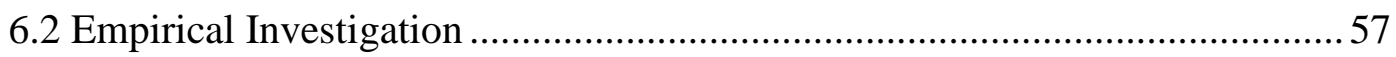

6.2.1 Data Employed and Dating the Cycles .................................................58

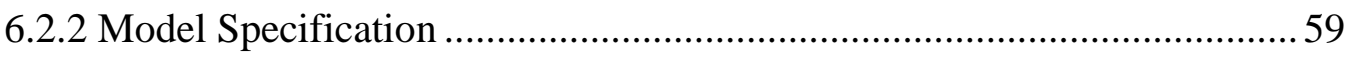

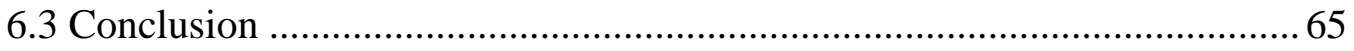

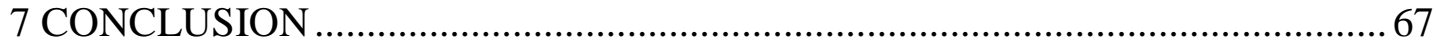

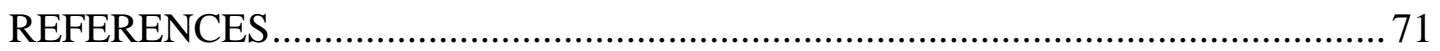

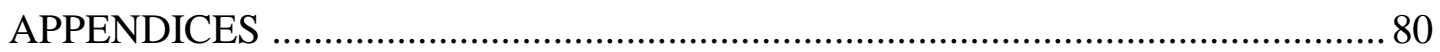

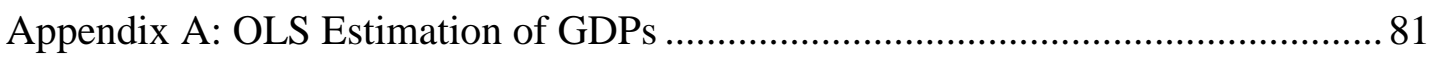


Appendix B: Dating the Business Cycles

Appendix C: Estimation of Random Walk Models ............................................... 100

Appendix D: Endogeneity Test Result................................................................. 101

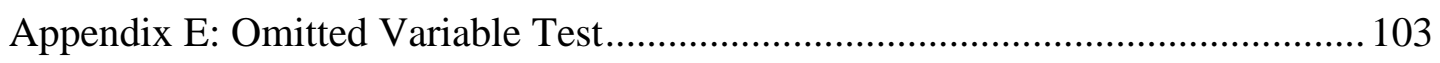

Appendix F: Estimation of Amplitude of Recessions ............................................. 106

Appendix H: Endogeneity Test Result ................................................................. 110

Appendix I: Omitted Variable Test ..................................................................... 112

Appendix J: OLS Estimations Expansion...................................115 


\section{LIST OF TABLES}

Table 1: Coefficients of Consumptions and Investments Regressed against GDP....27

Table 2: Correlations between Coefficients of Consumption and Investment with

Gini Index .28

Table 3: Correlations of the Average Gini Coefficients by Country and the

Characteristics of the Business Cycle 30

Table 4: The Correlations of Average Gini Coefficients by Country with Ratio of

Drift to Standard Deviations of GDP, Consumption and Investment 34

Table 5: Endogeneity Test Results................................................................ 50

Table 6: Omitted Variable Test for the Model in Equation 5.10 ..............................52

Table 7: OLS Estimation for Amplitude on the Gini Index....................................53

Table 8: Omitted Variable Test Results for the Model shown by Equation 5.12 ......54

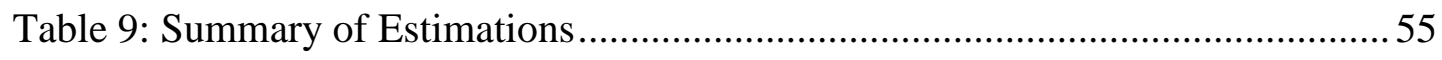

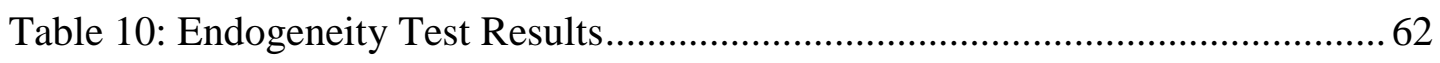

Table 11: Omitted Variable Test for the Model in Equation 6.1 ...............................64

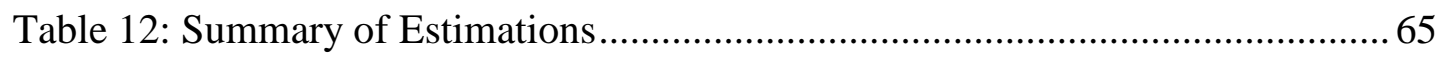




\section{LIST OF FIGURES}

Figure 1: Lorenz Curve................................................... 8

Figure 2: Duration, Amplitude and Cumulative Loss of the Phases of the Business

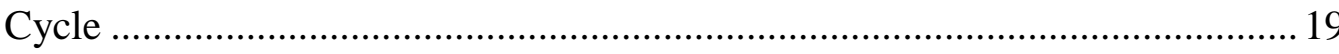

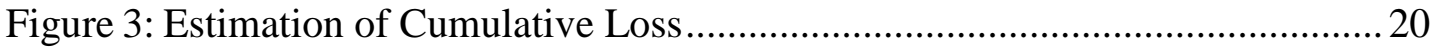




\section{LIST OF ABBREVIATIONS}

CTS

ETC

NBER
Contraction Terminating Sequence

Expansion Terminating Sequence

National Bureau of Economic Research 


\section{Chapter 1}

\section{INTRODUCTION}

\subsection{Background}

The importance of the distribution of output was first considered as a political economy issue by David Ricardo (1911). If we assume that output is produced by a combination of three main factors of production, namely land, labor and capital, the question is how this output must be shared among the owners of those factors to give them sufficient motivation to continue and perhaps expand production.

This question becomes more challenging if we assume that the availability of these factors of production are not limitless and are usually controlled by different individuals with different or sometimes with conflicting interests, who seek to satisfy their own interests. Indeed, if we consider to the definition of economics, which is the science of allocating scarce resources to competing uses, inevitably, it is clear that the modality of this allocation is an important issue. If it is not undertaken in a proper way, it may increase the superiority of one group of factor owners over others.

Despite the possible impact of distributional issues on the well-being of individuals within a country, the distributional issues have not always been a matter of concern among economists. For example, in the postwar period, particularly from the 1950s 
to the 1980s, income distributional issues attracted very little attentions among economists, researchers and policy makers. Perhaps because the aim of economists was mainly concentrated on efficiency issues rather than distributional issues at that time. In this regard, they were seeking to respond to welfare economics critiques raised by Pigou (1920), Robbins (1938) and Samuelson (1947), who emphasized the importance of society's social welfare function. Samuelson (1947) further argued that the individuals should not necessarily receive their imputed productivities because the resulting allocation of income might not be consistent with the optimization of society's welfare function.

Because of the great concern in the advanced countries of Europe and North America for achieving full employment the focus of economists shifted away from issues of income distribution to that of increasing employment while controlling inflation.

Indeed, when an economy experiences rapid growth with full employment, it was argued that the people at the bottom would benefit more from the increase in their real wages rather than from redistribution policies that takes income and perhaps wealth away from the wealthy individuals.

In the period following the world war II economic growth was experienced by many developed countries and unemployment rates fell and income inequality was reduced significantly. As a consequence the study of the differences in distributive outcomes of public sector interventions and policies to narrow this gap attracted little popularity among economists and policy makers. It was believed that that the cost of 
redistribution policies would be considerable and would have reduced the efficiency of the market economy.

During the period the emphasize of policies of neoclassical economics stressed the role of market signals in determining the factor prices for Pareto optimal resource allocation. In this model of competitive equilibrium to have efficient production all factors should be paid the value of their marginal products. Hence, the final result is a Pareto optimum in which no one can be made better off without making someone else worse off. This notion defines an "efficient" equilibrium that emphasizes on the distribution of initial endowments of income and, without considering the equal distribution of income as a final objective.

Since the early 1990s, many European countries have experienced, on average, a lower economic growth rate as compared to earlier decades. The primary consequence of this economic slowdown was rising unemployment rates. Hence, the policy position of these countries have gradually changed in favor of policies that promotes income equality. In recent years policies have been introduced to ease and support privatization. It was expected that the private sector would be better motivated to increase output by increasing efficiency and ultimately increasing the economic welfare of states. Nevertheless, these policy choices have not worked as expected to reduce income inequality among the individuals within the countries.

As a consequences many economists then have become convinced that they should take income distribution into consideration and analyze it along with the other important economic issues. Nowadays in many public economics debates the 
implications of income inequality within the countries attract much attention from economists (Atkinson \&Bourguignon, 2000). A good example of this phenomenon is recent studies of the relationship between growth and income distribution, which were undertaken usually by including distribution variables into economic models.

In this regard, economists intend to quantify the trade-off (if any) between income equality and economic growth. This is important since every country desires to achieve a high economic growth, whereas the fair distribution of income cannot be ignored. Meanwhile, not every country can succeed in fulfilling these two (somewhat) contradictory objectives at the same time. There exists a strand of literature, which emphasizes the tradeoff between income inequality and achieving a faster growth rate, which is basically influenced by the primary research conducted by Kuznets (1955) and Kaldor (1956) such that, today, this issue is conventional wisdom among economists.

Today it is a common belief among economists that the study of income distribution improves our understanding of various fields of economics such as political economy and public finance. However, despite this improvement, income distribution, except from Marxist economists' perspective still has not been a variable that plays a central role in economic models. But it is more like a parameter that affects other major variables. It seems that distribution must also be the object of the analysis in some sense to test how a more or less equal income distribution is able to play a fundamental role in our economy systems. 
In the study of the determinants and intensity of business cycles, the level of income equality of countries might be an important factor which has not received much attention to date. In this regard, if the income distribution of countries is considered in the center of analysis, it may improve our understanding about the nature and causes of business cycle.

The aim of this research is to theoretically and empirically examine the possible role of income inequality on the degree and intensity of business cycles of countries. To fulfill this aim 36 countries from different categories of income, namely higher income, higher middle income, lower middle income and low income, which all have different levels of Gini index, are chosen and the trends in their business cycles over the last 40 years are closely studied. In Chapter 2, we survey the related literature on income distribution, business cycles and their relationship. In Chapter 3, we explicitly discuss a method of dating business cycles, as proposed by Harding and Pagan (1999). In Chapter 4, an empirical study is conducted to find any possible association of income distribution as measured by the Gini index with duration, amplitude, and cumulative losses and gains of cycles. In addition, we break down the GDP into its two main components, consumption and investment, to date the cycles of consumption and investment and we then investigate the effects of income inequality on consumption and investment separately when the economy enters into recessions and expansions. Finally, assuming that GDP, consumption and investment follow a random walk with a drift model, efforts will be made to investigate the number of cycles of GDP, consumption and investment experienced by those countries over the last 40 years to find any association between the number of cycles in those variables and income inequality. In Chapter 5, we attempt to investigate the 
relationship between recession and income inequality by utilizing the instrumental variables as well as a regression model. Then we present a theoretical explanation for the findings based on the mathematical approaches. In Chapter 6, we concentrate on the relationship between income inequality and expansion of cycles using the same empirical approach as Chapter 5 and finally in chapter 7 we present our concluding remarks. 


\section{Chapter 2}

\section{LITERATURE REVIEW}

\subsection{Income Distribution}

\subsubsection{Overviews of Income Distribution}

Over the past decades there have been three different theoretical explanations for the differences between the distributions of income between different countries. These concepts mainly can be categorized as 1) functional distribution, 2) the extended functional distribution and finally 3 ) the size distribution.

The main discussion in the theory of the functional distribution of income is concentrated on the share of national income accrued by primary factors of production such as land, labor and capital. The extended functional distribution of income considers how the income allocated to these factors are divided between different sectors (i.e. agriculture, services,...) and this division will depend on the characteristics of different economies.

In contrast, the size distribution of income, differentiates residents of a country by different income levels, and hence, describes the shares of national income allocated to each group by (e.g. decile, quintile). Residents are classified as individuals, households, total population, economically active population. This definition of 
income distribution includes all sources of income, including transfers. To measure the size distribution of income the concept of the Lorenz curve has been proposed.

\subsubsection{The Lorenz Curve}

In the Lorenz curve, as displayed by figure 2.1, the horizontal axis represents the cumulative population in percentage point from poorest to richest, and the vertical axis represents the cumulative proportion of income received by $\mathrm{X}$ percent of population.

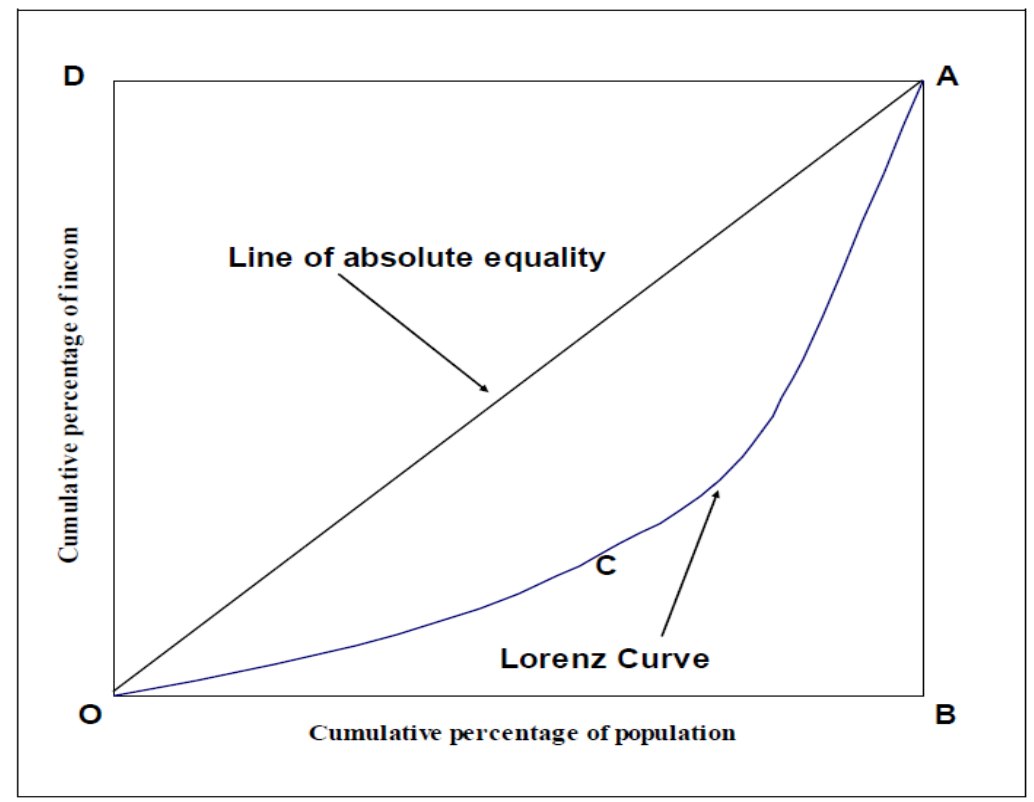

Figure 1. Lorenz Curve

In Figure 1, OA is the egalitarian line that represents the case of perfect equality of incomes. In contrast, when an economy experiences perfect inequality of income, the Lorenz curve coincides with the angle OBA, which indicates that all income is received by only one individual within the society. In that sense, the Lorenz curve captures the inequality of income by exerting the deviation of each individual's 
income from perfect equality as represented by the OA hypotenuse in the above diagram.

However, in order to compare the size distribution of income between countries or over time we need to draw a number of such curves for different countries. It is quite possible to observe that the poorest and the richest quintile shares in one country are relatively less than their counterparts in another country. Hence, we need to employ other inequality techniques (present the measures by a unique index) that permit an accurate ranking assessment of countries in terms of their income inequality. For this study, the focus will be made on the Gini index, which has been extensively used in economic research.

\subsubsection{The Gini Coefficient}

Geometrically, the Gini coefficient, named after the Italian statistician in 1912, can be stated as the total area of the Lorenz Curve. Considering the above diagram, the Gini coefficient can be calculated by the area occupied between the Lorenz curve, OCA, and the diagonal OA, divided by the area occupied by the triangle OBA. Therefore, it is computable by following formula ${ }^{1}$

The Gini coefficient $=$ Area between the Lorenz curve and diagonal / Total area under the diagonal

This coefficient ranges from 0 , when all incomes are equal, to 1 where the Lorenz curve overlaps the OB and BA line and has a $\rfloor$ shape. Hence, a 0 Gini coefficient

\footnotetext{
1 The details explanation can be found in
} 
means perfect equality of income distribution whereas a Gini coefficient equivalent to 1 indicates the perfect inequality of income distribution.

\subsection{Business Cycle}

The concept of classical business cycles, initially presented by Burns and Mitchell (1946), defines the business cycle as the recurrent fluctuations observed in the aggregate economic activity of a nation over time. Therefore, every business cycle consists of an expansion followed by a contraction that is reviving to the next cycle. According to this definition, the duration of a fluctuation usually takes between two to twelve years and a cycle is characterized by its average duration, amplitude and the co-movement between economic variables and business cycles.

The traditional view of business cycles emerges from Keynesian economists who first presented his ideas in the 1930s. They postulate a business cycle as a phenomenon that contains three characteristics. The first states that the business cycles are temporary movements in economic variable such as real GNP. The second is the fact that business cycles hurt a country's economic welfare. Finally, the third indicates that monetary and fiscal policies can be used to stabilize the economy by eliminating some of the ups and downs in economic variables. They further indicated that the fluctuation in the marginal efficiency of capital works as an engine to generate business cycles. In this regard, when optimism expectations about marginal efficiency of capital rise, the response is an excessive investment, which ultimately will end up as an economic boom. The other extreme, when investors become pessimistic about the marginal efficiency of capital, the economy enters a recession. Keynes also mentioned that the existence of inventory costs and capital depreciation 
(during the downturn) are two major reasons that cause the recovery of the business cycle after it experiences a downturn.

This postulate leads to the classification of cycles into recessions, troughs, expansions and peaks. The important implication of this classification is that recessions and expansions are a temporary deviation from a long-term trend in real variable such that, for instance, during a recession GDP or GNP falls below its longterm trend. In contrast, it exceeds its long-term trend during an expansion period. Hence, as the economy returns to its long-term trend this loss or gain will be restored. The implication of the third characteristic that underlies business cycles is that active government policies should be used to smooth fluctuations in business cycles. There always has been a dispute about the extent to which monetary policy can be used to reduce the severity of business cycles.

There also exists a strong historical relationship between the growth in money supply and business cycle such that the changes in the rate of monetary growth can be the primary determinant of cyclical variations in employment, income and inflation. Monetarists consider the monetary growth as a factor causing fluctuations rather than a passive reaction to those fluctuations. There are three types of evidence proposed by Friedman and Schwartz (1963) to explain the monetary business cycles: the pervasive influence of money on other economic variables, the persistence of the association between monetary growth and business cycles during periods and the observed timing relationship between changes in the rate of monetary growth and changes in other economic variables. 
Friedman and Schwartz believed that money is capable to influence a wide variety of important economic aggregates and hence plays a major role in explaining aggregate economic relationships. They also cited that appreciable changes in the rate of monetary growth have been accompanied by appreciable changes in other aggregate economic variables. These occurred whether the changes in monetary growth was due to an external factor or a policy decision. To support the view that the association between monetary growth and business cycles primarily reflects the independent influence of money on the rest of the economy, they showed that the changes in the rate of growth of the money supply generally precede changes in economic activity and inflation.

While the Keynesians and the monetarists propose the aggregate demand (particularly random and temporary fluctuations in private investment and consumption) and the money supply, respectively, is a primary source of business fluctuations, the real business cycle theories indicate that shocks on aggregate supply is a major cause of economic fluctuations. The supporters of real business cycle theories particularly emphasize the importance of technological shocks and claim that since these shocks are permanent, therefore the supply shocks could also be permanent. According to their viewpoints, to a large extend the business fluctuations can be accounted by for real shocks rather than nominal shocks, and unlike the other precedent business cycle theorists they consider recessions and period of economic growth as the efficient response to exogenous changes in the economy rather than a failure for market to clear. 


\subsection{Income Inequality, GDP Growth and Business Cycle}

In the 1950s Simon Kuznets was one the first researchers who presented the idea that there exists an inverted-U relationship between per capita gross national product (GNP) and inequality in income distribution. Kuznets, estimated the income distribution in a few countries with different levels of income, and examined the patterns of income inequality in selected European countries over a period of time (Perkins et al, 2001). He developed the idea that as per capita income rises in less developed countries, income inequality also rises to reach a maximum, and then declines as income levels rise further. His results were later popularized as the “Inverted-U Hypothesis." In the following years, the income inequality began to rise in many developing countries, to support his idea that income distribution will be more equal within the countries as the economic development advances.

Assane and Grammy (2003), using US data, concluded that economic growth causes inequality, Clarke (1995) claimed that if a country experiences severe income inequality, the poor citizens force the government to redistribute the accumulated wealth. This can be made through levying high taxes on wealthier individuals that ultimately lowers the return on individuals' assets and restricts capital accumulation and eventually slows down the growth rate. Hence, despite the fact that this process might redistribute the wealth more evenly, eventually, the growth rate could be negatively affected by income inequality. These results were supported by Alesina and Rodrik (1991) and Persson and Tabellini (1994) using cross-country growth regression analysis. Similar studies were conducted by Perotti (1996) and Benabou (1996) concerning the income distribution and economic growth. 
Barro (2000) presented a theoretical analysis of the macroeconomic mechanisms to support his empirical findings that income inequality is related to economic growth. Bengoa and Sanchez-Roblez (2005) designed an endogenous model to include equality as an argument that increases the utility of a representing agent. They concluded that the relationship between equality and growth was hump shaped, whereas the impact of equality on growth could be different at various stages of development. This conclusion was somewhat supported by Birdsall (2007), who indicated that inequality is more likely to harm growth in countries possessing less than US\$3200 GDP per capita (in 2000 dollars), and this effect emerges at high levels of inequality where the Gini coefficient is greater than 0.45 .

Berg et al. (2012), using the multi-decade and multi-country data, proposed that greater equality can sustain growth. They constructed their analysis on a tentative consensus in the growth literature and concluded that inequality can undermine progress in health and education, causing political and economic instability. This undercuts the social consensus required to adjust the economy when a country faces major shocks. Therefore, inequality tends to reduce the pace and durability of growth.

From a broader perspective, Dadkhah (2006) implemented a study of the causality and feedback of the relationship between equality and the growth through the application of a VAR model in conjunction with time-series data on the U.S. economy for the period of 1947 to 2001 . He proposed that there is a two-way positive relationship between a more equal distribution of income and a higher rate 
of economic growth. In other words, applying any policy that promotes income equality will encourage growth, and vice versa.

With regard to the relationship between business cycles and income distribution, one of the primary researches has been done by Bishob et al. (1991), who applied a stochastic dominance model, to analyze the impacts of growth and recessions on income distribution in the U.S. for the period 1967-1986. Their primary objective was investigating how growth and recessions have influenced the well-being of specific income groups and classes. Their findings indicate that individuals in upper income level positions suffered less from the adverse effects of recessions compared to those in lower income levels. Furthermore, they benefit more than lower income level individuals during the expansion period.

Burkhauser et al. (1999), using kernel density estimation techniques, described the distribution of household size-adjusted real income and explained how it changed over the business cycle of the 1980s in the U.S. and the U.K. They showed that income inequality increased in the two countries and the middle of the distribution was reduced. Also, using a series of statistical tests, they found that while during the expansion period both lower and higher income level individuals took the advantage of this economic growth, the higher income level individuals benefited more than lower income level individuals. In addition, using threshold and momentum models of co-integration, developed by Enders and Granger (1998) and Enders and Siklos (2001), they attempted to test the difference between the impacts of economic expansions and contractions on income distribution. They also employed the impulse response functions based on the Vector Error Correction model to analyze feedback 
effects between income distribution and the business cycles. Their findings support the idea that increases in unemployment cause increases in income inequality. In contrast, the negative shocks to unemployment have only short-lived positive benefits to income inequality. Therefore, those individuals with the lowest mean family income (sorted by quintile) are most adversely affected by recessions but are also the quickest to return to the steady state. Hoover et al. (2009) reached somewhat the same results, indicating that during recession periods an increase in unemployment intensifies the income inequality, but during expansion periods a reduction in the unemployment rate has a short-lived effect on reducing income inequality. Maliar et al. (2005) employing a neo-classical growth model showed that in the U.S. economy over time, inequality in both wealth and income follows a counter-cyclical pattern during business cycles.

In this thesis, the cause of income inequality is studied from another perspective to this investigation focuses on the degree of severity of the business cycles that affect countries with different levels of income distribution, and whether this effect is greater in relation to consumption or investment. It seems that the consumptionsmoothing behavior of consumers in the countries with a less inequality of income, along with the investment behavior of individuals will help these countries to experience a less costly recession. In addition, it is important to know whether the severity of business cycles emerges from longer durations or deeper amplitudes. Finally, it would be interesting to explore any possible relationship between income inequality and the number of cycles in GDP, consumption and investment that countries might experience. In this regard, the role of uncertainty and the speed of information flow, as well as the degree of effectiveness of fiscal and monetary 
policies, might lead us to observe a greater number of cycles in investment and a lower number of cycles in GDP and consumption for countries with less income inequality. 


\section{Chapter 3}

\section{DATING THE BUSINESS CYCLE}

This study of business cycles focuses on the "classical cycle" approach, along with the non-parametric method associated with NBER as a method of dating business cycles. For this purpose as Harding and Pagan (1999) stated, a few steps need to be followed. First, the turning points of the series representing the aggregate activities must be explored. To determine these points, an automated algorithm that performs at least three tasks is required. This algorithm determines the potential turning points in a series, including peaks and troughs. In addition, this procedure must ensure that the obtained peak and troughs alternate over time. Finally, after defining a censoring rule to re-combine turning points established in the previous steps, it should fulfill some criteria to identify the length and depth of phases and complete cycles. These censoring rules ensure that the phases of each cycle have a minimum duration of six months and a complete cycle have a minimum duration of fifteen months. When measuring the severity of a cycle, it is important to focus on three measures (see Figure 3.1.). The duration of Contraction Terminating Sequences (CTS) is shown as $\mathrm{AB}$, and the duration of Expansion Terminating Sequences (ETS) is shown as BC; the amplitude of the phases of the cycle "di" are shown by the vertical lines inside the cycle in Figure 3.1, and the cumulative losses and gains within each phase of the cycles, are shown by the area PTM for the CTS phase and the area MTD for the ETS phase. 


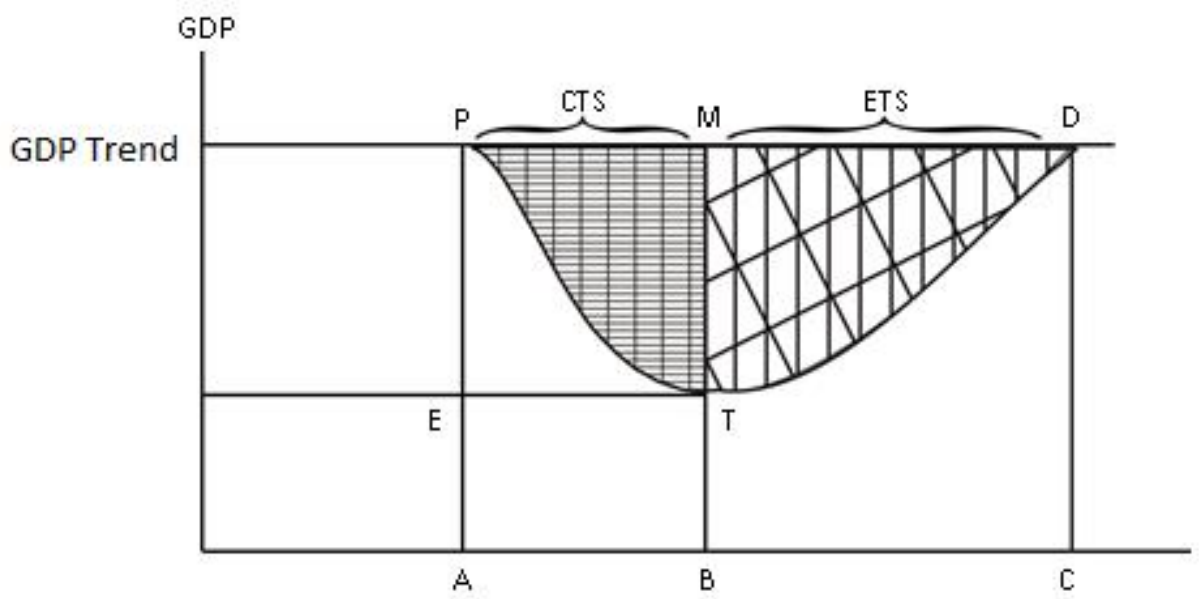

Figure 2: Duration, Amplitude and Cumulative Loss of the Phases of the Business Cycle

As Arthur Okun proposed, a recession must involve at least two quarters of negative growth such that $\mathrm{ETS}=\{\Delta Y(t+1)<0, \Delta Y(t+2)<0\}$ represents a peak at time t. Likewise, an expansion starts if two quarters of positive growth are experienced, That is, $\mathrm{CTS}=\{\Delta Y(t+1)>0, \Delta Y(t+2)>0\}$.

To obtain the measures of duration, amplitude and cumulative losses of each cycle, as proposed by Harding and Pagan (1999), we consider a phase as a triangle where the height of the triangle shows the amplitude and its base represents the duration. As soon as these two elements are known, it enables us to calculate the area of the triangle representing an approximate measure of the total losses in GDP from peak to trough, as compared to the previous peak. A typical recession phase of output can be shown graphically as in the Figure 3.2. 


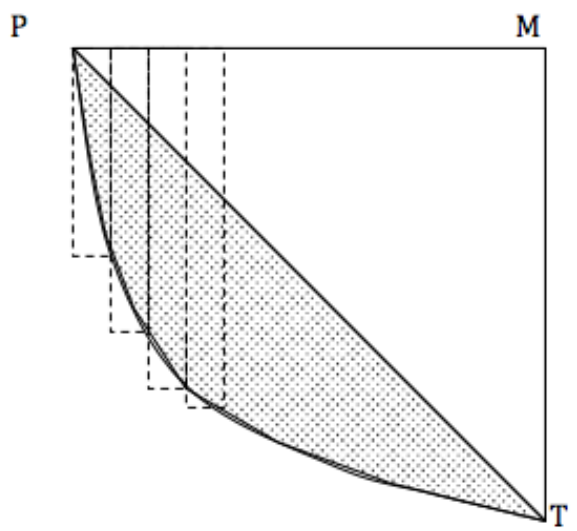

Figure 3: Estimation of Cumulative Loss of a Cycle

The "triangle approximation" as Harding and Pagan (2002) name it, exerts the recession phase where the height of the triangle shows the amplitude $A_{i}$ (representing the total loss in output from peak $\mathrm{P}$ to trough $\mathrm{T}$ ) and the base of the triangle shows the duration $D_{i}$ of the phase (representing how long it takes for the recession phase to be completed from peak $\mathrm{P}$ to trough $\mathrm{M})$.

Therefore the area of the triangle PMT in figure 3.1 measures the cumulated loss of each cycle of output from peak to through. Assuming that the base of each small triangle is equal to one unit of duration, the best approximation of the area of PMT can be computed as

$$
P M T=C_{i}-\frac{1}{2} \sum_{t=1}^{T} a_{t}
$$

Where $C_{i}$ represents the area of each rectangle as shown by shaded lines, and $a_{t}$ stands for the height of each small triangle in which its hypotenuses is tangent to the actual path of cycles (figure 3.2). However, in practice, the triangle approximation may be different from the actual path of the phase. Therefore, to catch those 
movements fully, we need to introduce an index that represents those excess cumulated movements. This has been calculated by Harding and Pagan (2002) and explained in detail by Vahid and Athanasopoulos (2001) as follows;

$$
E_{i}=\frac{1 / 2 \sum_{t=1}^{T} a_{t}+1 / 2 D_{i} \Sigma_{t=1}^{T} a_{t}-C_{i}}{D_{i}}
$$

The excess index graphically evaluates parametric models of the business cycles and describes the deviation of the actual business cycle from its respective triangle approximation. It worth noting that the cumulative gain and excess of cumulative gain on recovery or expansion phase of a cycle can be calculated by the same manner.

The application of this dating method provides the average durations and amplitudes of all the cycles identified over the period. The algorithm, then, calculates the percentage loss and gain in GDP at each period, compare to its precedent period, and present the result as an average cumulative loss or gain for all the cycles that experienced by every individual country over the period. By the same way, it calculates the excess index or deviation from the cycles and presents the result on average basis.

For this study, to compute these values for each individual country using Gauss program, given that the data employed are annual data, we replace Calculus for BBQ in the formula. Also we employ icensor1, K_ETS=1 and L_LTS=1 to ensure that a minimum length of cycle is one year and yt is a local maximum relative to the one year on either side of $y t$ throughout. 


\section{Chapter 4}

\section{INCOME DISTRIBUTION AND THE BUSINESS CYCLE}

\subsection{Introduction}

Since the 1950s, the study of the business cycle and its impact on income inequality has been the topic of many investigations. Most of this research aimed to study the dynamic or static impact of a business cycle on income distribution within countries. Although some of these studies, theoretically and empirically, highlight these impacts, very little is known about the possible association of income inequality with the severity of business cycles and the number of business cycles that a country may experience over time. Likewise, as an economy enters a recession, how quick and deep the collapses of aggregate demand occur in countries with a less equal income distribution. Finally, does greater inequality of incomes within a country affect the cyclical patterns of business cycles? These relationships may help to understand whether countries with more or less equal distribution of income can cope better with the economic shocks that create recessions. Dating the cycles of GDP, consumption and investment shows how the severity of these cycles are correlated with the Gini index values of countries and how they may affect the cyclical patterns of business cycles.

The initial objective of this study is to find out how the degree of responsiveness of consumption and investment to GDP varies between countries with different levels 
of Gini index values. For this purpose, we run an OLS method for a set of 36 countries over a period of 40 years. A correlation is then made between all the estimators of consumption and investment with the average of Gini indices of countries over the past 40 years. This analysis is carried out to determine whether consumption or investment is the leading variable causing fluctuations of GDPs.

The second objective is to find a possible relationship between the degree of income inequality and the severity of business cycles shown as the duration and depth of recessions and expansions for the countries under study. To identify true business cycles that affect GDPs followed by consumptions and investments, we employ the algorithm proposed by Harding and Pagan (1999) to date the cycles of GDPs, consumptions and investments. These are calculated for each individual country during the period 1970 to 2009 . A set of correlations is then made between the value of the estimates of these parameters for the 36 countries for 40 years and the average of the Gini index values reported for each individual country. This analysis shows whether income inequality is associated with a more or less intense recession and expansion. This also demonstrates how consumption and investment may play a role in intensifying or alleviating the effects of business cycles in countries with different levels of income inequality.

As a final objective of the chapter, the number of cycles in GDP, consumption and investment is calculated for all the countries over the course of 40 years. For this purpose, a random walk model with a drift for consumption, investment and GDP of each country is separately estimated to obtain the ratio of drift to standard deviation. A correlation is then made between these ratios with the Gini index values of the 
countries, to highlight the possible relation between income distribution and the number of cycles in each of the three mentioned variables.

In this study we employ annual data on GDP, consumption and investment for all 36 selected countries over the years 1970 to 2009 reported by the World Bank. Annual data on the Gini index values are also collected from World Bank. It seems that greater income inequality is correlated with less sensitivity of GDP to consumption and more sensitivity of GDP to investment. In addition, more income inequality leads to a longer and deeper recession in which the role of consumption in alleviating the effects of economic shocks that create recessions is less significant for countries with a less equal income distribution. Finally, greater income inequality is correlated with a greater number of cycles in GDP and consumption, and with a lower number of cycles in investment.

\subsection{Dating the Cycles}

Following the dating method described in the preceding chapter, the turning points of the data series for GDP, consumption and investment must first be explored. To determine these points, the algorithm that determines the potential turning points of the series (peaks and troughs) is employed. This algorithm follows the Okun's rule, which requires a recession to have at least two quarters of negative growth. Likewise, an expansion starts only if two quarters of positive growth are experienced. Then it selects only those episodes where the peaks and troughs alternate. To identify the peaks and troughs, as mentioned before, the concepts of (a) contraction terminating sequences (CTS) and (b) expansion terminating sequences (ETS) are employed. 
Over the 40-year period covered by this study the Harding and Pagan algorithm identifies the true cycles for each individual country based on a set of censoring rules. It also calculates the areas of loss accumulated for each phase of the cycles. It then calculates the average (percentage) loss for each phase separately across all the business cycles experienced by a country (1970-2009) with respect to the GDP trend for each country at the time of the business cycle.

\subsection{Data}

We select 36 countries for which annual data on GDP, consumption and investment are available from 1970 to 2009 from the World Development Indicators of the World Bank (World Bank, 2011). Using the GDP deflator, these data are transformed to constant 2000 local currency units (in millions). The data on Gini indices of countries are also collected from the World Bank for the years 1980 to 2009. Given that the applied algorithm for dating the cycles calculates and presents a single average value for the duration, amplitude and cumulative loss of the contractionary and expansionary phase of the cycles for each individual country over the period of 1970 to 2009 , for consistency of study we also calculate an average of the estimated Gini indices for each country. All the correlations throughout this study are made between these average numbers. It should be noted that since the Gini indices data of all the countries under study were not available for the years before 1980, we assume that inaccessibility to those data will not significantly harm our results, since the deviation of those data from the mean is assumed to be minor. 


\subsection{Empirical Approach and Related Arguments}

\subsubsection{Coefficients of Investment and Consumption}

As a first step, an ordinary least square model (OLS) is estimated for GDPs of selected countries in order to obtain the related estimators of consumption and investment (Table1). We then group our sample into three sets of countries. The first includes the full sample of countries. The second group contains 21 countries that fall into the high and higher middle income group: Argentina, Australia, Brazil, Canada, Chile, Denmark, France, Germany, Greece, Ireland, Japan, Malaysia, Mexico, New Zealand, Norway, South Africa, Spain, Sweden, Turkey, United Kingdom and United States. The third group is the 15 countries that are classified as lower middle income and low income: Benin, Bolivia, Burundi, China, Congo Republic, Gabon, Gambia, Guinea, India, Jordan, Kenya, Morocco, Philippines, Tunisia and Zambia. The negative correlation of those estimators with the average of Gini index of all countries in the first group (Set 1) reveals that the responsiveness of GDP to consumption is greater for the countries with less income inequality (Table 2). This correlation is significant at a $99 \%$ confidence level. This responsiveness falls considerably when we compare high and middle income countries (Set 2) with low and lower middle income countries (Set 3), as shown in Table 2. This is consistent with the Keynesian theory which indicates that as the income distribution improves, the average propensity to consume (APC) will rise, leading to higher consumption. However, the positive sign of the respective correlation between the Gini indices and investment coefficients leads us to conclude that responsiveness of GDP to investment falls as income distribution improves. This conclusion, however, is not as strong as the previous conclusion for consumption, since this value is only 
significant at the $95 \%$ confidence level. Nevertheless, this responsiveness increases considerably when we compare high and middle income countries (Set 2) with low and lower middle income countries (Set 3) as shown in Table 2, showing that GDP in low income countries is more sensitive to variation in investment.

Table 1: Coefficients of Consumptions and Investments Regressed against GDP (Year 1970-2009)

\begin{tabular}{|c|c|c|c|c|c|c|c|}
\hline Country & $\begin{array}{l}\text { GINI } \\
\text { INDEX }\end{array}$ & CONSUMPTION & INVESTMENT & Country & $\begin{array}{l}\text { GINI } \\
\text { INDEX }\end{array}$ & CONSUMPTION & INVESTMENT \\
\hline Argentina & 47.92 & 0.46 & 0.31 & Turkey & 42.78 & 0.88 & 0.09 \\
\hline Australia & 35.00 & 0.80 & 0.22 & UK & 36.00 & 0.86 & 0.11 \\
\hline Brazil & 58.46 & 0.78 & 0.23 & US & 41.00 & 0.82 & 0.09 \\
\hline Canada & 33.00 & 0.79 & 0.20 & Benin & 39.00 & 0.76 & 0.08 \\
\hline Chile & 55.17 & 0.75 & 0.25 & Bolivia & 54.13 & 0.59 & 0.36 \\
\hline Denmark & 25.00 & 0.87 & 0.08 & Burundi & 35.25 & 0.75 & 0.03 \\
\hline France & 33.00 & 0.84 & 0.17 & China & 42.00 & 0.64 & 0.39 \\
\hline Germany & 28.00 & 0.91 & 0.16 & Congo & 47.00 & 0.62 & 0.56 \\
\hline Greece & 34.00 & 0.73 & 0.23 & Gabon & 41.00 & 0.51 & 0.44 \\
\hline Ireland & 34.00 & 0.91 & 0.15 & Guinea & 43.25 & 0.55 & 0.24 \\
\hline Japan & 25.00 & 0.77 & 0.21 & Gambia & 48.50 & 0.39 & 0.36 \\
\hline Malaysia & 44.67 & 0.63 & 0.26 & India & 37.00 & 0.80 & 0.27 \\
\hline Mexico & 48.62 & 0.76 & 0.25 & Jordan & 38.00 & 0.70 & 0.23 \\
\hline $\begin{array}{l}\text { New } \\
\text { Zealand }\end{array}$ & 35.00 & 0.84 & 0.14 & Kenya & 47.67 & 0.59 & 0.33 \\
\hline Norway & 26.00 & 0.90 & 0.34 & Morocco & 39.44 & 0.63 & 0.09 \\
\hline $\begin{array}{l}\text { South } \\
\text { Africa } \\
\end{array}$ & 58.00 & 0.83 & 0.18 & Philippines & 43.33 & 0.85 & 0.13 \\
\hline Spain & 35.00 & 0.83 & 0.07 & Tunisia & 41.67 & 0.81 & 0.12 \\
\hline Sweden & 25.00 & 0.82 & 0.10 & Zambia & 50.25 & 0.74 & 0.21 \\
\hline
\end{tabular}

Source: World Bank, 2011 
Table 2: Correlations between Coefficients of Consumption and Investment with Gini Index

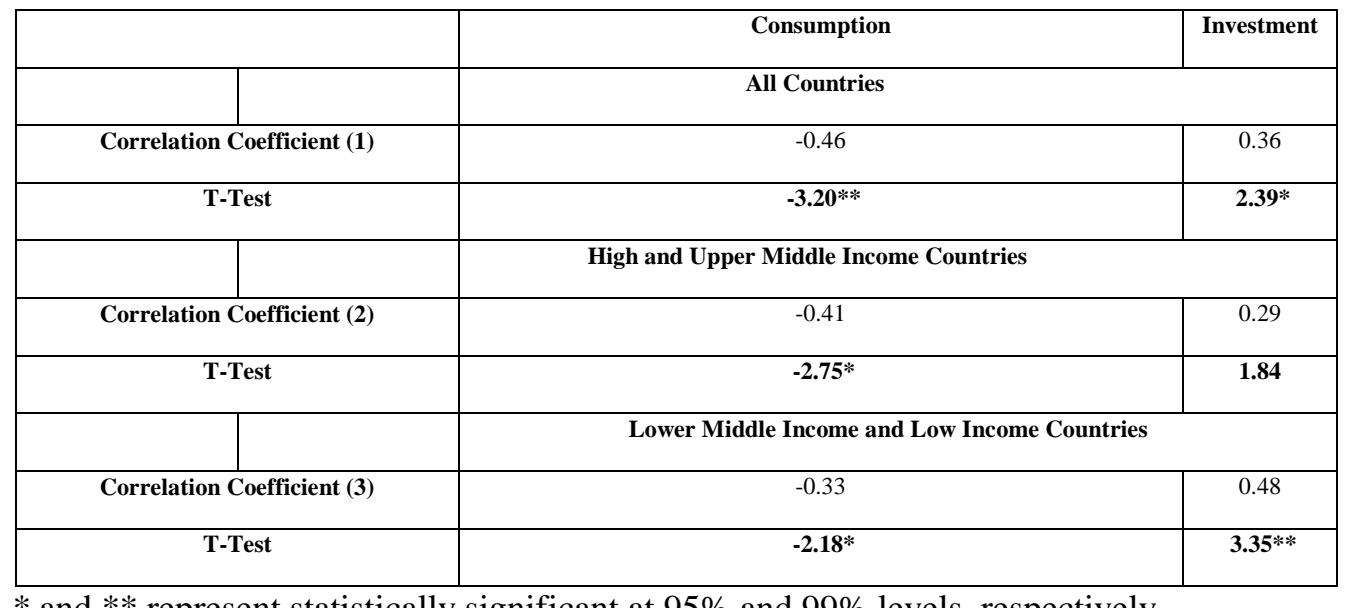

$*$ and $* *$ represent statistically significant at $95 \%$ and $99 \%$ levels, respectively.

The reason for this may relate to the fact that owing to a shortage of capital, the rate of return on capital in less developed countries (which mostly have high Gini indices (Garth Frazer 2006)) is higher in comparison to developed countries. Therefore, the GDP in those countries seems more sensitive to investment variation. This clarification will help us to understand how consumption and investment play their role in intensifying or alleviating the effect of business cycles experience by countries with different levels of income inequality.

\subsubsection{Income Inequality and GDP, Investment and Consumption}

In this step, the dating procedure is undertaken to obtain the average duration, amplitude and cumulative loss for peak to trough (CTS) and trough to peak (ETS) of cycles of GDP, consumption, and investment. The countries are grouped into three categories as previously described, and correlations are made between the average Gini indices of countries with the average values obtained for duration, amplitude and cumulative loss of each phase of the business cycle. The findings of this empirical investigation are reported in Table 3. 
In the full sample of 36 countries it can be seen that the correlation coefficients between the Gini indices and the duration, amplitude and cumulative loss in GDP of the contractionary phase of the cycle are positive and significant at either a 95 or 99\% confidence level (Table 4, Row 1). This result strongly supports the hypothesis that income inequality (higher Gini index) is associated with longer durations, deeper amplitude, and greater cumulative losses in GDP as economy enters to recession. 
Table 3: Correlations of the Average Gini Coefficients by Country and the Characteristics of the Business Cycle

\begin{tabular}{|c|c|c|c|c|c|c|c|c|c|c|c|c|c|c|c|c|c|c|}
\hline & \multicolumn{6}{|c|}{ GDP } & \multicolumn{6}{|c|}{ Consumption } & \multicolumn{6}{|c|}{ Investment } \\
\hline & \multicolumn{3}{|c|}{$\overline{\text { CTS }}$} & \multicolumn{3}{|c|}{ ETS } & \multicolumn{3}{|c|}{ CTS } & \multicolumn{3}{|c|}{ ETS } & \multicolumn{3}{|c|}{ CTS } & \multicolumn{3}{|c|}{ ETS } \\
\hline & DUR & AMP & CUM & DUR & AMP & CUM & DUR & AMP & CUM & DUR & AMP & CUM & DUR & AMP & CUM & DUR & AMP & CUM \\
\hline & \multicolumn{18}{|c|}{ Full Set of Countries } \\
\hline Correlation & 0.35 & 0.53 & 0.36 & -0.22 & -0.11 & -0.07 & 0.08 & 0.52 & 0.30 & -0.41 & 0.05 & -0.10 & -0.01 & 0.33 & 0.19 & -0.28 & 0.25 & 0.03 \\
\hline 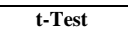 & $2.18^{*}$ & $3.60^{* * *}$ & $2.28^{*}$ & -1.31 & -0.64 & -0.41 & 0.49 & $3.51^{* * *}$ & 1.85 & $-2.64 *$ & 0.29 & -0.58 & -0.07 & $2.01^{*}$ & 1.13 & -1.71 & 1.48 & 0.20 \\
\hline & \multicolumn{18}{|c|}{ High and Upper Middle Income Countries } \\
\hline$\frac{1}{\text { Correlation }}$ & 0.53 & 0.83 & 0.67 & -0.24 & -0.12 & -0.17 & -0.07 & 0.73 & 0.55 & -0.45 & -0.12 & -0.04 & 0.18 & 0.39 & 0.30 & -0.37 & 0.22 & 0.04 \\
\hline t-Test & $2.7 * *$ & $6.42 * *$ & $3.95^{* * *}$ & -1.09 & -0.54 & -0.76 & -0.28 & $4.66^{* * *}$ & $2.89^{* * *}$ & $-2.19^{*}$ & -0.54 & -0.19 & 0.79 & 1.82 & 1.35 & -1.71 & 0.97 & 0.16 \\
\hline & \multicolumn{18}{|c|}{ Low and Lower Middle Income Countries } \\
\hline Correlation & -0.28 & -0.17 & $\begin{array}{c}-0.30 \\
\end{array}$ & 0.18 & 0.27 & 0.32 & 0.18 & \begin{tabular}{l|l|}
-0.09 \\
\end{tabular} & \begin{tabular}{c|}
-0.13 \\
\end{tabular} & -0.10 & 0.26 & $\begin{array}{ll}0.03 \\
\end{array}$ & 0.38 & 0.11 & 0.21 & $\begin{array}{l}-0.20 \\
\end{array}$ & $\begin{array}{l}0.09 \\
\end{array}$ & -0.09 \\
\hline t-Test & \begin{tabular}{l|l|}
-1.67 \\
\end{tabular} & $\begin{array}{l}-1.01 \\
\end{array}$ & -1.81 & 1.08 & 1.63 & 1.97 & 1.05 & -0.51 & \begin{tabular}{c|}
-0.76 \\
\end{tabular} & -0.57 & 1.55 & 0.20 & $2.39^{*}$ & 0.64 & 1.25 & -1.20 & 0.51 & -0.50 \\
\hline
\end{tabular}

$*$ and $* *$ represent statistically significant at $95 \%$ and $99 \%$ levels, respectively. 
When we look at the duration, amplitude and cumulative loss of cycles in consumption and investment as major components of GDP for the full set of countries, The positive sign of correlations for duration, amplitude and cumulative loss shows that the income inequality is significantly associated with a longer duration, deeper amplitude and greater cumulative loss of GDP. In addition, the sign of correlations with duration of cycles shows that we may observe longer duration in cycles of consumption and shorter duration in cycles of investment for the countries with less equal income distributions. Likewise, we may observe a larger cumulative loss in cycles of consumption and investment for the countries with less income equality. However, none of these results are significant. But when we look at the amplitude of cycles in consumption and investment, we observe that inequality of income is significantly associated with deeper cycles in consumption and investment, and that this correlation is more significant for consumption than for investment ( $1 \%$ level of significance versus $5 \%$ level of significance).

Looking at the second set of countries, we observe that only consumption plays a significant role in alleviating the effects of shocks (0.55), although the sign of the correlation coefficient for investment shows that investment may play some role in this direction (0.30). Another important implication of these results is that, as a shock hits the economy, regardless of whether the upcoming crisis is classified as an inertial or a realistic scenario (Josifidis et al. 2010), both consumption and investment play some role in alleviating its effects for countries that have more equal income distributions. However, this role seems to be more effective for consumption than for investment (0.30 versus 0.19$)$. Given that GDP in countries with less income 
inequality is more sensitive to variations in consumption than those in investment, the consumption-smoothing behavior of a large middle income group of consumers as well as better access to the credit market helps those countries to sustain their GDP at a higher level and to experience a less costly recession.

The empirical results of the full set of countries also reveal that there is a negative correlation between the Gini index and the duration, amplitude and cumulative gain of the expansion phase of the cycles of GDP (ETS). Hence, those countries with greater income inequality (higher Gini index) may experience a shorter and less deep period of recovery from a recession, although these numbers are not statistically significant. The reasons behind these facts can be explained by considering the importance of the consumption-smoothing theories such as the permanent income hypothesis and the life-cycle model of consumption for people with different levels of income. As shown by Amorosi et al. (2012), consumption smoothing by middle income households is higher, while investment decisions are affected by the concepts of uncertainty and irreversibility.

The importance of uncertainty has also been emphasized by many researchers, who have concluded that uncertainty suppresses investment, since higher uncertainty actually reduces the responsiveness of investment to demand shocks This is due to the fact that investment decisions on installed capital must take into account future cost and demand conditions, even though this reaction may be more severe for riskaverse firms. (Holland, and Riddiough 2000; Bloom et al., 2007; Stein and stone, 2012). 


\subsubsection{Income Distribution and the Number of Business Cycles}

Given that output processes in a variety of real business cycle (RBC) models follow a random walk with a $\operatorname{drift}\left(\Delta Y_{t}=\mu_{y}+\sigma e_{t}\right)($ Cogley and Nason 1995), we estimate such a model for GDP, consumption and investment separately for each country. These are carried out to compute the ratio of the drift to standard deviation $(\mu / \sigma)$ in order to determine the number of turning points of the cycles. According to Harding and Pagan (1999), in this typical model, $\Phi(-\mu y / \sigma)$ shows the probability that one quarter of negative growth could be obtained, where the cumulative normal distribution is shown by $\Phi($.$) , and (\sigma)$ stands for standard deviation. In this case, the ratio of drift to standard deviation shows the number of turning points such that a larger $\mu_{Y} / \sigma$ indicates that fewer turning points can be identified in a series (Don Harding and Adrian Pagan, 1999).

Taking the correlations between the Gini indices and the ratio of drift to standard deviation of GDP, consumption and investment for the entire set of countries reveals that countries with less equal income distributions are likely to experience a higher number of cycles in GDP and consumption. This is shown by the negative sign of their respective coefficient correlations where these correlations are statistically significant at the 95\% and 99\% confidence levels respectively (Table 4). Looking at the second set of countries (higher income and upper middle income), this effect is stronger for GDP, but almost the same for consumption. However, the correlations for the third set of countries (lower middle and low income) predict the same outcome even though the obtained coefficients are not statistically significant. In contrast, the correlation coefficients for the Gini indices and investment for the first 
and second sets of countries have a positive sign, leading to the conclusion that greater income inequality is consistent with a lower number of cycles in investment. The insignificant $t$-test value for investment, however, does not strongly support this conclusion.

Table 4: The Correlations of Average Gini Coefficients by Country with Ratio of Drift to Standard Deviations of GDP, Consumption and Investment

\begin{tabular}{|c|c|c|c|}
\hline & GDP & Consumption & Investment \\
\hline & \multicolumn{3}{|c|}{ Full Set of Countries } \\
\hline Correlation Coefficient (1) & -0.33 & -0.44 & 0.15 \\
\hline \multirow[t]{2}{*}{ t-Test } & $-2.07 *$ & $-2.85 * *$ & 0.94 \\
\hline & \multicolumn{3}{|c|}{ High and Upper Middle Income Countries } \\
\hline Correlation Coefficient (2) & -0.6 & -0.49 & 0.22 \\
\hline \multirow[t]{2}{*}{ t-Test } & $-3.3 * *$ & $-2.85 * *$ & 0.98 \\
\hline & \multicolumn{3}{|c|}{ Lower Middle and Low Income Countries } \\
\hline Correlation Coefficient (3) & -0.11 & -0.24 & -0.08 \\
\hline t-Test & -0.4 & -0.91 & 0.94 \\
\hline
\end{tabular}

The fact that the numbers of peaks and troughs in consumption and GDP become less as income distribution improves over the countries may be due to the higher degree of effectiveness of fiscal and monetary policies in developed countries. However, in order to understand the reason for observing more volatile investment patterns in countries with a more equal income distribution, we need to examine the relationship between investment and flow of information as well as uncertainty and the flow of information affecting investment decisions in advanced countries.

As Strebulaev et al. (2012) pointed out, the investment decision no matter resourced from equity or debt is sensitive to the flow of information. Emphasizing the role of uncertainty Bernanke (1983) stated that the timing of irreversible investment projects 
can be quite sensitive to the arrival of new information. He suggested that if we have a realistic assumption that these uncertainties will be reviewed periodically in the light of new information, we may observe more fluctuations in investment, especially in more developed countries, since the flow of information is faster than that in developing countries.

\subsection{Conclusions}

From the empirical results it would appear that a less equal income distribution leads to deeper and more costly recessions. Overall, the duration of contraction when going into a recession is longer for countries with a less equal distribution of income, while the sign of estimations show that the speed of recovery during the expansionary phase of a recession (ETS) seems to be somewhat faster. The duration and depth of the decline of aggregate demand in the first phase of the cycle (CTS) results in greater cumulative income losses of GDP for countries that have greater inequality.

Moreover, we show that greater income inequality is associated with a smaller responsiveness of GDP to consumption and greater responsiveness of GDP to investment. In this case we observe that during the recession, consumption in countries with greater income inequality plays a greater role in pulling the economy down compared to investment, while for the countries with less income inequality, consumption alleviates the effects of recession to prevent GDP from entering deeper recession. In addition, a higher level of income equality will lead to a lower number of cycles in GDP and consumption. The same conclusion cannot be drawn as clearly for investment. 


\section{Chapter 5}

\section{INCOME DISTRIBUTION AND RECESSIONS}

\subsection{Introduction}

In the previous chapter the application of simple correlation and t-test proposed that there is a strong association between the income inequality and the severity of recessions shown by cumulative loss in GDPs. However, in this chapter this relationship is investigated by employing a more advanced empirical method as well as a theoretical justification for the proposed relationships.

Thus, the initial objective of this chapter is to seek for the same relationship between the degree of income inequality and the severity of recessions for the countries under study. For this purpose, we first sketch the theoretical background of this issue based on the models of four components of aggregate demand that move during a recession; namely consumption, investment, net export and governmental spending, to highlight that the income distribution within countries may affect these movements. This theoretical background proposes a solid justification for empirical findings of this chapter and the previous one. To carry out the empirical analysis, we employ the same algorithm proposed by Harding and Pagan (2002) for dating the cycles of GDP for each individual country over the period 1970- 2009. In addition, in order to investigate the effect of Gini index on cumulative loss of GDPs in different countries, two separate methods of ordinary least squares (OLS) and two-staged least 
squares (TSLS) are employed assuming that Urban Population (UPOP) and the Telephone Lines $(T L)$ are instrumental variables (used to run the TSLS method) and the Real Interest Rate $(R I R)$ and Inflation Rate $(I R)$ are omitted variables from our structural models (OLS and TSLS). This demonstrates how income equality within the countries may play a role in intensifying or alleviating the effects of recessions in countries under study.

For the purpose of this study we employ annual data on GDP for all 36 selected countries over the years 1970 to 2009 reported by the World Bank. Annual data on Gini indices are also collected from World Bank. The theoretical and empirical discussions presented below indicate that countries with a more equal income distribution, on average, will experience a less costly recession.

\subsection{The Relationship between the Movement of the Components of Aggregate Demand and the Distribution of Income}

The theoretical background for this chapter is based on the methods of four components of aggregate demand that move during a recession, namely consumption, investment, net export and governmental spending, and the possible role that income distribution may play in affecting these movements.

\subsubsection{Consumption}

The consumption theory of Keynes (1936) proposed that consumption was positively related to income but was a diminishing function of income. This is due to the fact that marginal propensity to consume and average propensity to consume fall as the level of income increases. The implication is that a redistribution of income towards equality has a positive effect on aggregate consumption. Kuznets (1946) challenged Keynes's theory, claiming that in the long run the average propensity to consume is 
constant, while in the short run the data support Keynes's theory. Friedman (1956), in putting forward the permanent income hypothesis, argued that households' expenditures in any period are a function of their permanent incomes, which is consistent with Kuznets' results. Although the permanent income hypothesis of Friedman and the lifecycle method of Modigliani prevailed for decades, recent research in the field has placed greater emphasis on the relative permanent income hypothesis proposed by Duesenberry (1948) to explain consumption behavior. The empirical work by Alpizar et al. (2005) confirms that it is the relative levels of income and consumption over time that matter for people. Palley (2010) developed a synthetic Keynes-Duesenberry-Friedman method and concluded that low-income households have a higher marginal and average propensity to consume. The primary implication of this result is that the redistribution of income is likely to have a positive effect on aggregate demand. Therefore, tax cuts in countries with a more equal distributive income are likely to have a more expansionary effect than cuts in countries with less equality. Since tax cuts are a common tool for stimulating the economy, particularly during periods of recession, it is anticipated that this policy will work more effectively in reducing the effects of recession in countries with a more equal income distribution. Moreover, as shown by Sun et al. (2013), countries with a more equal income distribution suffer less from credit constraints because more of the population in such countries has access to capital markets. This acts to alleviate the intensity of recession in countries that enjoy more equal income distribution. 


\subsubsection{Investment}

In order to explore how investment behavior differs between countries with different income distributions, we need to split our analysis into two parts. First, we need to study how income distribution may affect the transfer of investment to the next period, and second, we need to examine how the trade-off between human capital transfer and physical capital transfer takes place during this process.

\subsubsection{Transfer to the next period}

We analyze the behavior of rich individuals and poor individuals separately, and combine their behavior by including another variable representing the proportion of rich and poor individuals in the model. This determines the aggregate effect of income distribution on transfers to the next period.

\section{Wealthy Individuals}

We assume that the income of wealthy individuals within an economy originates from their real wage $\left(W_{t}^{R}\right)$ in time t, plus the returns earned on bonds $\left(r b_{t}^{R}\right)$. The wages of wealthy individuals is set equal to the base wage plus a return on his human capital $\left(W_{t}^{R}=w_{t}+h_{t} H_{t}^{R}\right)$ where $w_{t}$ is the base wage rate and $H_{t}^{R}$ is the human capital and $h_{t}$ is the rate of return on human capital at time t. Their total outflow will be allocated to current period consumption $\left(C_{t}^{R}\right)$, and investment in the stock of human capital $\left(H_{t+1}^{R}-H_{t}^{R}\right)$ and physical capital $\left(b_{t+1}^{R}-b_{t}^{R}\right)$. Equation 5.1 shows this relationship.

$$
W_{t}^{R}+r b_{t}^{R}=C_{t}^{R}+\left(b_{t+1}^{R}-b_{t}^{R}\right)+\left(H_{t+1}^{R}-H_{t}^{R}\right)
$$


Rearranging this equation provides the transfer equation for each wealthy individual within a country as follows:

$$
b_{t+1}^{R}+H_{t+1}^{R}=W_{t}^{R}+r b_{t}^{R}-C_{t}^{R}+b_{t}^{R}+H_{t}^{R}
$$

This equation clearly indicates that in each period, rich individuals spend a proportion of their income (whether wage or bonds income) on current consumption, and the rest will be transferred to the next period by increasing their human or physical capital.

Poor Individuals

Similarly, poor individuals spend a proportion of their income on current consumption and may transfer a proportion (if any remains) to the next period. The only difference here is that poor individuals are assumed to have zero wealth and zero human capital accumulated from the previous period. Therefore, their wages are set equal to a base wage rate $\left(W_{t}^{P}=w_{t}\right)$ Although they are able to increase their base wages by gaining experience over time, it is assumed for now that they have no job experience at all. The transfer equation in this case will be:

$$
b_{t+1}^{P}+H_{t+1}^{P}=W_{t}^{P}-C_{t}^{P}
$$

where $W_{t}^{P}=w_{t}$ in this equation.

Aggregate Transfer

If we assume that $\lambda$ represents the proportion of rich people in country, the total transfer function will be shown as:

$$
\text { Total transfer }=\lambda \sum_{1}^{n}\left(b_{i, t+1}^{R}+H_{i, t+1}^{R}\right)+(1-\lambda) \sum_{i}^{n}\left(b_{i, t+1}^{p}+H_{i, t+1}^{p}\right)
$$

Rearranging this equation will give us equation below (5.4) 
Total transfer $=\lambda \sum_{1}^{n}\left(b_{i, t+1}^{R}-b_{i, t+1}^{p}\right)+\lambda \sum_{1}^{n}\left(H_{i, t+1}^{R}-H_{i, t+1}^{p}\right)+\sum_{1}^{n} b_{i, t+1}^{p}+\sum_{1}^{n} H_{i, t+1}^{p}$

Given that $b_{t+1}^{R}>b_{t+1}^{p}$ and $H_{t+1}^{R}>H_{t+1}^{p}$, as $\lambda$ increases, the total transfer to the next period will increase. This result clearly indicates that there is an inverse relationship between the inequalities of income across a country and the transfer to the next period. In another words, as the proportion of poor people in a country is reduced, the total transfer (physical or human capital) to the next period will rise.

\subsubsection{Trade-off between $b_{t+1}$ and $H_{t+1}$}

Today, human capital constitutes the largest component of wealth for most people such that two-thirds of total income is allocated to labor income in most developed countries.

The recent studies on the effect of education on earnings shows that the monetary return on human capital varies from $7 \%$ to $12 \%$ which is approximately the same magnitude as the returns to financial assets. Palacios-Huerta (2003a) further showed that for the specific groups the return could rise to 20\%. Furthermore, Elias (2003) estimated the non-monetary benefits of education around $16 \%$ for the total return to human capital assets. All these emphasize the importance of human capital that should be taken into account when the consequences of business cycles are studied.

To discuss how the individual's tendency varies toward investing on human or physical capital during a recession/expansion period, one needs to apply a dynamic utility maximization model that incorporates the individual's consumption and investment behavior. 
Wei (2003) constructed a stylized dynamic general equilibrium model proposing one-agent complete-market framework to study of human capital variation during business cycle as well as its asset pricing implications.

The model was studied under three different scenarios including productivity shocks, human capital shocks and the joint productivity and human capital shocks where as Krebs (2003) showed that human capital shocks can occur as a result of changes in labor market conditions.

Wei (2003) incorporated the labor-leisure-education choices into utility function of a representative individual and assumed that her preference is non-separable over consumption and leisure to allow her risk attitude varies towards consumption over time with the relative importance between the two. He also assumed that the economy is populated by a large number of homogeneous agents and markets are complete. Assuming that the individual has one unit of time, which is divided among leisure, education and labor supply, and the firm demands the required labor force through Cobb-Douglas production function, he sets a series of constraints including physical capital accumulation, human capital accumulation and etc. to solve the central planer's problem.

Wei (2003) introduced the hours spent in education in his model and asserted that there is a negative correlation between the education and output. In his empirical estimations of this relationship he found that the correlation is greater $(-0.76)$ when 
human capital shocks are the only type of uncertainty in the economy $(-0.41$ in the case of productivity shocks, and -0.40 in the case of joint productivity and human capital shocks). These results support the empirical findings of Dellas and Sakellaris (2003) and Spilimbergo (2000) who showed that the times spend on education is countercyclical.

The implications from an asset-pricing model proposed by Wei (2003) revealed that during an economic downturn, individuals tend to build up their human capital, with the expectation of a higher wage income and larger non-market benefits from human capital in the future.

These results indicate that although the equality of income distribution is associated with a greater transfer of investment to the next period, during a recession a considerable proportion of these transfers tend to be towards human capital rather than physical capital for the countries with a more equal income distribution. In such countries, these transfers indirectly boost consumption for the subsequent periods and alleviate the intensity of decline in GDP rather than shifting towards internal capital stock to seek for investment opportunities.

\subsubsection{Net Export}

The positive relationship between equality of income distribution and international trade has been emphasized by Krugman (1981), Helpman and Krugman (1985), Ondrich et al. (2006) and Yan (2007). AS Caruana et.al. (2000) emphasized, a domestic recession does spur firms to expand their export activities. 
If a country is export-led and the recession is assumed not to be a global recession, an exporting firm will suffer relatively less since it may be able to offset the fall in the domestic demand with a rise in volume of exports abroad. In contrast, if the country does not produce goods that are both domestically consumed as well as exported, during a recession when aggregate demand is reduced then the prices of the outputs of the firms must fall causing the firms to reduce their supply to the domestic market. This will further exacerbate the recession. The net result is that if aggregate demand in a country is impacted for some reason its ultimate impact on domestic supply is likely to be relatively greater on those firms who do not have to option to increase their exports.

Indeed, it is evident from the data set used in this study that most of the countries with a high Gini index are still in the early stages of development. These countries do not have many firms, outside of agriculture, that are producing for both the domestic as well as the export markets. In such a situation they are not able to take advantage of foreign trade to maintain their level of production during a domestic recessionary period. Firms in countries with less income inequality have greater capacity to export items such as manufacturing commodities that are sold both domestically as well as abroad.

\subsubsection{International Governmental Borrowing}

International governmental borrowing is one of the approaches followed to stimulate the economic growth rate when a crisis hits the economy. As it is evidenced, governmental spending in small amounts can stimulate the economy (Tanninen, 1999). However, this opportunity is not available to all countries to an equal extent. 
The countries are ranked on the basis of a number of economic, financial, social and political indicators. The integrated analysis of these factors usually determines the countries' position and sovereign credit rating, which indicates their ability to repay debts. DBRS, one of the most prominent institutes that undertakes these integrated analyses to rank countries based on their sovereign creditability, groups risk factors into six categories, namely fiscal management and policy, debt and liquidity, economic structure and performance, monetary policy and financial stability, balance of payments and political environment. Each of these risk factors contains a number of quantitative and qualitative variables that are taken into consideration to determine sovereign credit rating. Among these variables, revenues, expenditures, fiscal balance, budget planning and control, historical growth and its prospects, demography and income equality, and financial system stabilities are the most influential determinants of credit rating, with all of these having a positive effect on creditability of sovereigns.

In fact, a government's ability to generate sustainable revenue in the future to pay off the current debt plays a significant role in evaluating the importance of other variables in this context. However, as Aizenman and Jinjarak (2012) showed, higher income inequality is associated with a lower tax base, and hence a lower tax revenue, lower de facto fiscal space and higher sovereign spreads. Since tax revenues are considered the most sustainable governmental revenues, a narrower tax base limits the fiscal flexibilities of a government's revenue generation. 
Indeed, the data indicate that there is a negative correlation $(-0.37)$ between international debt as a percentage of GDPs and the Gini index of the sample countries studied in this research, with this correlation being statistically significant at the $95 \%$ level.

Considering the expected behavior of each of these components of aggregate demand, we should expect to find some empirical evidence of the impact of income distribution on the severity of recession.

\subsection{Empirical Investigation}

In order to empirically address this question it is first necessary to measure the severity of recessions for each country. The algorithm developed by Harding and Pagan (2002) is used for this purpose; the algorithm not only identifies the potential turning points, but also ensures that these peaks and troughs alternate over time. In this way the true business cycles are identified along with their respective durations, amplitudes and cumulative impacts. These are calculated for each individual country and the result is presented as an average number over the period 1970-2009. Two separate methods are estimated using ordinary least squares (OLS) and two-staged least squares (TSLS) to investigate the effect of the Gini index (as explanatory variable) on duration, amplitude and cumulative loss of the contractionary phase of cycles, as these are carried out under the scenario that the Urban Population (UPOP) and the Telephone Lines $(T L)$ are instrumental variables (used to run the TSLS methods). The Real Interest Rate $(R I R)$ and Inflation Rate $(I R)$ are assumed to be omitted variables from our structural models (OLS and TSLS). 


\subsubsection{Data Employed and the Cycle Dating Approach}

For the purpose of this chapter, the annual data on GDP for selected 36 countries from year 1970 to 2009 reported in the World Development Indicators (World Bank, 2011) is used. Similar to the previous chapter the data are transformed to constant 2000 local currency units (in millions) using GDP deflator. The data on Gini indices of countries are also collected from the World Bank for the years 1980 to 2009. In this chapter we only focus on contractionary phase (CTS) of the cycle and similar to the previous chapter we apply the same algorithm for dating the cycles to calculate duration, amplitude and cumulative loss of those phases of the cycles for each individual country over the period of 1970 to 2009.

\subsubsection{Model Specification}

Because the proposed algorithm presents the calculation results of duration, amplitude and cumulative losses of cycles on average basis, for the consistency of our final result the average Gini index for each country over the period of study is estimated. In order to investigate the extent to which income inequality may affect the recession, the effect of the Gini index on each component of duration, amplitude and cumulative loss of the contractionary phase of a cycle is examined. A typical model is formed as follows:

$$
Y_{i}=\beta_{0}+\beta_{1} * \text { Gini }+\varepsilon_{i} \quad i=1,2,3
$$

where $Y_{1}, Y_{2}, Y_{3}$ represent duration $(D U R)$, amplitude $(A M P)$ and cumulative loss $(C U M)$, respectively, of the contractionary phase of cycles.

However, this model might suffer from an endogeneity problem (existence of a correlation between Gini index and $\varepsilon_{1}$ as an error term) in which the application of 
the OLS method will eventually produce a bias result (Bullock et al., 2010). In order to avoid such a problem, instrumental variables must be employed. These must satisfy two conditions in order to be considered reliable instrumental variables. First, there must be a strong correlation between each of the instrumental variables and the Gini index. Second, in contrast, there must be no correlation between each of the instrumental variables and the residuals of the Equation $5.10\left(\varepsilon_{1}\right)$. This requires us to choose two variables, $U P O P$ and $T L$, as instrumental variables for this model, in which both variables satisfy the abovementioned conditions reasonably well, where the obtained estimators of the model

$$
G i n i=b_{0}+b_{1} * U P O P+b_{2} * T L+u_{1}
$$

are significantly different from zero, and where R-squared (0.59) and $F$-statistics (24.138) are high enough to prove that the chosen instruments are not weak for this model (Stock et al., 2002). Hence, Equation 5-10 can be transformed to

$$
Y_{i}=\beta_{0}^{*}+\beta_{1}^{*} * \hat{G i n i}+\varepsilon_{2 i}
$$

\section{人}

where the Gini is the predicted value from equation (5.11) and the TSLS method is used in order to obtain the estimators of this model (Foster and McLanahan, 1996; Greene, 1993).

While our instrumental variables in Equation 5.11 are significant in their explanation of the value of the Gini coefficient, an endogeneity test needs to be undertaken to choose whether the model shown in Equation 5.10 or that in Equation 5.12 should be estimated in order to find an unbiased estimator. For this purpose, a Hausman test is conducted. As Hausman (1978) proposed, in this case, the Gini index is shown to be 
exogenous (and instrumental variables could be omitted to obtain more accurate results) if there is no correlation between the error term in Equation 5.11 and the dependent variable of Equation 5.10. To examine this, an OLS method is first conducted for Equation 5.11 and its error term used as an explanatory variable for Equation 5.10. Hence, the following equation needs to be estimated using the OLS method:

$$
Y_{i}=\varphi_{0}+\varphi_{1} * \text { Gini }+\delta * u_{1}+\varepsilon_{3 i}
$$

The null hypothesis to be tested is $\delta=0$, which proves that the Gini index is an exogenous variable. If the null hypothesis is rejected so that $\delta$ becomes statistically significant, it can be concluded that the Gini index is an endogenous variable. Hence, obtaining an unbiased result necessitates the estimation of Equation 5.12. On the other hand, if the null hypothesis is not rejected, it can be concluded that the Gini index is an exogenous variable, and estimation of Equation 5.10 is sufficient to produce a reliable conclusion. The result of endogeneity tests (Equation 5.13), as shown in Table 5, asserts that the Gini index is an exogenous variable, since the residuals of Equation $5.11(R E S)$ are not significantly related to the duration, amplitude and cumulative loss. 
Table 5: Endogeneity Test Results

\begin{tabular}{|c|c|c|c|c|}
\hline \multicolumn{5}{|c|}{$D U R=\mathrm{C}(1)+\mathrm{C}(2) * G I N I+\mathrm{C}(3) * R E S$} \\
\hline Variable & Coefficient & Std. Error & $t$-Statistic & Prob. \\
\hline GINI & 0.030807 & 0.001662 & 18.53846 & 0 \\
\hline RES & -0.021158 & 0.012 & -1.76313 & 0.0869 \\
\hline R-squared & 0.143991 & \multicolumn{2}{|c|}{ Adjusted R-squared } & 0.118814 \\
\hline Prob. ( $F$-statistics $)$ & 0.047559 & DW & 2.053201 & \\
\hline \multicolumn{5}{|c|}{$A M P=\mathrm{C}(1)+\mathrm{C}(2) * G I N I+\mathrm{C}(3) * R E S$} \\
\hline Variable & Coefficient & Std. Error & $t$-Statistic & Prob. \\
\hline GINI & 0.356157 & 0.091163 & 3.906834 & 0.0004 \\
\hline$R E S$ & -0.217545 & 0.143068 & -1.52057 & 0.1379 \\
\hline $\mathrm{C}$ & -9.545134 & 3.72064 & -2.56546 & 0.015 \\
\hline R-squared & 0.33793 & \multicolumn{2}{|c|}{ Adjusted R-squared } & 0.297805 \\
\hline Prob. $(F$-statistics $)$ & 0.001109 & DW & 2.200317 & \\
\hline \multicolumn{5}{|c|}{$C U M=\mathrm{C}(1)+\mathrm{C}(2) * G I N I+\mathrm{C}(3) * R E S$} \\
\hline Variable & Coefficient & Std. Error & $t$-Statistic & Prob. \\
\hline GINI & 0.322157 & 0.104175 & 3.092474 & 0.004 \\
\hline$R E S$ & -0.291412 & 0.163489 & -1.78245 & 0.0839 \\
\hline $\mathrm{C}$ & -9.026917 & 4.251701 & -2.12313 & 0.0413 \\
\hline R-squared & 0.225769 & \multicolumn{2}{|c|}{ Adjusted R-squared } & 0.178846 \\
\hline Prob. ( $F$-statistics $)$ & 0.014687 & DW & 2.373391 & \\
\hline
\end{tabular}

These results indicate the Gini is endogenous at $10 \%$ level of significance for DUR and CUM. Therefore, the instrumental variables should be included (since the coefficients of RES for duration and cumulative loss are o significant at 10 percent level of significance). However, this conclusion can not be made for AMP. Hence, there is a need to estimate both Equation 5.10 (using the OLS method) and Equation 5.12 (using the TSLS method) to compare the results.

In addition, there may be other variables that affect the average duration, amplitude and cumulative losses of the contractionary phase of cycles, but that are excluded from the above models. As King et al. (1994) observed, if 'relevant variables are omitted, our ability to estimate causal inferences correctly is limited'. In order to tackle this problem, it is necessary to run an omitted variable test. For this purpose there is a need to find some variables that affect the contractionary phase of business cycles such that their inclusion in Equation 5.10 or Equation 5.12 may change the 
result. In theory, the rate of productivity and the interest rate, RIR, lie at the center of the discussion, since they have the greatest effect on the business cycles. Where the data for productivity rate for the selected countries between 1970 and 2009 is not available, $R I R$ and $I R$ are chosen for the omitted variable test (World Bank, 2012).

Thus, to implement this research both Equation 5.10 and Equation 5.12 are estimated, assuming that $R I R$ and $I R$ are omitted variables of these models. The omitted variable test is then conducted for both methods to see whether the inclusion of $R I R$ and $I R$ significantly changes the results. Table 6 shows the estimation results of Equation 5.10 (assuming that the Gini index is an exogenous variable, while RIR and $I R$ are assumed to be omitted variables). 
Table 6: Omitted Variable Test for the Model in Equation 5.10

\begin{tabular}{|c|c|c|c|c|}
\hline \multicolumn{5}{|c|}{$D U R=\mathrm{C}(1)+\mathrm{C}(2) * G I N I+\mathrm{C}(3) * R I R+\mathrm{C}(4) * I R($ Omitted Variables: $R I R I R)$} \\
\hline$F$-Statistic & 12.69816 & \multicolumn{2}{|c|}{ Prob. (F-Statistics) } & 0.0001 \\
\hline Likelihood Ratio & 21.03279 & \multicolumn{2}{|c|}{ Prob. (Likelihood) } & 0 \\
\hline & Coefficient & Std. Error & $t$-Statistic & Prob. \\
\hline $\mathrm{C}$ & 0.964976 & 0.27042 & 3.568428 & 0.0012 \\
\hline Gini & 0.001434 & 0.006894 & 0.207931 & 0.8366 \\
\hline$R I R$ & 0.025594 & 0.00908 & 2.818791 & 0.0082 \\
\hline$I R$ & 0.00144 & 0.000829 & 1.737072 & $0.092 \underline{0}$ \\
\hline R-squared & 0.519962 & \multicolumn{2}{|c|}{ Adjusted R-squared } & 0.474958 \\
\hline$F$-Statistic & 11.55378 & \multicolumn{2}{|c|}{ Prob. $(F$-Statistics $)$} & 0.000027 \\
\hline DW & 2.170703 & & & \\
\hline \multicolumn{5}{|c|}{$A M P=\mathrm{C}(1)+\mathrm{C}(2) * G I N I+\mathrm{C}(3) * R I R+\mathrm{C}(4) * I R($ Omitted Variables: $R I R I R)$} \\
\hline$F$-Statistic & 1.41788 & \multicolumn{2}{|c|}{ Prob. $(F$-Statistics $)$} & 0.257 \\
\hline Likelihood Ratio & 3.056707 & \multicolumn{2}{|c|}{ Prob. (Likelihood) } & 0.2169 \\
\hline & Coefficient & Std. Error & $t$-Statistic & Prob. \\
\hline $\mathrm{C}$ & -5.10115 & 3.272476 & -1.5588 & 0.1289 \\
\hline Gini & 0.220803 & 0.083433 & 2.64647 & 0.0125 \\
\hline$R I R$ & 0.156032 & 0.10988 & 1.42002 & 0.1653 \\
\hline$I R$ & -0.00098 & 0.010033 & -0.0973 & 0.9231 \\
\hline R-squared & 0.349214 & \multicolumn{2}{|c|}{ Adjusted R-squared } & 0.288203 \\
\hline$F$-Statistic & 5.723763 & \multicolumn{2}{|c|}{ Prob. (F-Statistics) } & 0.002973 \\
\hline DW & 2.359582 & & & \\
\hline \multicolumn{5}{|c|}{$C U M=\mathrm{C}(1)+\mathrm{C}(2) * G I N I+\mathrm{C}(3) * R I R+\mathrm{C}(4) * I R($ Omitted Variables: $R I R I R)$} \\
\hline$F$-Statistic & 3.915704 & \multicolumn{2}{|c|}{ Prob. (F-Statistics) } & 0.0301 \\
\hline Likelihood Ratio & 7.881114 & \multicolumn{2}{|c|}{ Prob. (Likelihood) } & 0.0194 \\
\hline & Coefficient & Std. Error & $t$-Statistic & Prob. \\
\hline $\mathrm{C}$ & -1.63628 & 3.539782 & -0.46225 & 0.647 \\
\hline Gini & 0.095401 & 0.090248 & 1.057093 & 0.2984 \\
\hline$R I R$ & 0.224954 & 0.118855 & 1.892676 & 0.0675 \\
\hline$I R$ & 0.006115 & 0.010853 & 0.563481 & 0.577 \\
\hline R-squared & 0.318109 & \multicolumn{2}{|c|}{ Adjusted R-squared } & 0.254181 \\
\hline$F$-Statistic & 4.976097 & \multicolumn{2}{|c|}{ Prob. (F-Statistics) } & 0.006032 \\
\hline DW & 2.456398 & & & \\
\hline
\end{tabular}

The implications of these results are that in all models there exists at lease one variable that is significantly different from zero. (Shown by $F$-test). However, RIR and IR could be dropped from AMP if the level of significance is chosen to be $10 \%$. Likewise, IR could be dropped from CUM. The surprising result is that the Gini is not statistically significant for none of above models. The result of endogeniety test and omitted variable test for AMP assert that we can safely drop IVs, RIR and IR 
from AMP and run an OLS method to see the variation of AMP as Gini changes. The result is presented in table 7.

Table 7: OLS Estimation for Amplitude on the Gini Index

\begin{tabular}{|c|c|c|c|c|}
\hline \multicolumn{5}{|c|}{ AMP= C(1)+C(2)*GINI } \\
\hline Variable & Coefficient & Std. Error & $t$-statistic & Prob. \\
\hline Gini & 0.26783 & 0.071602 & 3.740535 & 0.0007 \\
\hline C & -5.99214 & 2.950741 & -2.03073 & 0.0502 \\
\hline R-squared & 0.291543 & Adjusted R-squared & 0.270706 \\
\hline Prob. $(F$-statistic) & 0.000677 & DW & 2.356323 & \\
\hline
\end{tabular}

As this result shows, the Gini index coefficient is statistically significant at the $1 \%$ level of significance, which indicates that a less equal income distribution will deepen the amplitude of recessions experienced by countries.

On the other hand, if we assume that the Gini index is an endogenous variable, it is necessary to run a TSLS method similar to that represented by Equation 5.12 for duration, amplitude and cumulative loss of the contractionary phase of cycles. As long as there is one explanatory variable (Gini index) and two instrumental variables (TL and UPOP) in this typical model initially, a Sargan test (J-test) (as proposed by Sargan (1958) and Hansen (1982)) must be undertaken to ensure that the model is not over-identified. The computed restricted J-test for duration, amplitude and cumulative loss regressions prove that the models are not over-identified. ${ }^{2}$ Therefore we can safely run the omitted variable test of TSLS method assuming that UPOP and TL are IVs and RIR and IR are assumed to be omitted variables. The results are presented in table 8 .

\footnotetext{
${ }^{2} \mathrm{~J}$-stats are greater than chi-squared (3.84), and therefore the null hypothesis that $T L$ and UPOP do not belong to the model is rejected.
} 
Table 8: Omitted Variable Test Results for the Model shown by Equation 5.12

\begin{tabular}{|c|c|c|c|c|}
\hline \multicolumn{5}{|c|}{$D U R=\mathrm{C}(1)+\mathrm{C}(2) * G I N I$} \\
\hline \multicolumn{5}{|c|}{ Instrument specification: $T L U P O P$} \\
\hline \multicolumn{5}{|c|}{ Omitted variables: $R I R I R$} \\
\hline & Coefficient & Std. Error & $t$-Statistic & Prob. \\
\hline $\mathrm{C}(1)$ & 0.532345 & 0.312985 & 1.700864 & 0.0981 \\
\hline $\mathrm{C}(2)$ & 0.017793 & 0.007595 & 2.342721 & 0.0251 \\
\hline R-squared & 0.138986 & \multicolumn{2}{|c|}{ Adjusted R-squared } & 0.113662 \\
\hline$F$-statistic & 5.488341 & \multicolumn{2}{|c|}{ Prob. $(F$-statistic $)$} & 0.025134 \\
\hline DW & 2.18895 & \multicolumn{2}{|c|}{ Restricted J-statistic } & 2.413994 \\
\hline & & \multicolumn{2}{|c|}{ Unrestricted J-statistic } & $2.00 \mathrm{E}-38$ \\
\hline Difference in J-stats & 2.413994 & \multicolumn{2}{|c|}{ Prob. (Difference in J-stat) } & 0.2991 \\
\hline \multicolumn{5}{|c|}{$A M P=\mathrm{C}(1)+\mathrm{C}(2) * G I N I$} \\
\hline \multicolumn{5}{|c|}{ Instrument specification: $T L U P O P$} \\
\hline \multicolumn{5}{|c|}{ Omitted variables: $R I R I R$} \\
\hline & Coefficient & Std. Error & $t$-Statistic & Prob. \\
\hline $\mathrm{C}(1)$ & -5.99214 & 2.950741 & -2.03073 & 0.0502 \\
\hline $\mathrm{C}(2)$ & 0.26783 & 0.071602 & 3.740535 & 0.0007 \\
\hline R-squared & 0.291543 & \multicolumn{2}{|c|}{ Adjusted R-squared } & 0.270706 \\
\hline$F$-statistic & 13.9916 & \multicolumn{2}{|c|}{ Prob. $(F$-statistic $)$} & 0.000677 \\
\hline DW & 2.356323 & \multicolumn{2}{|c|}{ Restricted J-statistic } & 5.777965 \\
\hline & & \multicolumn{2}{|c|}{ Unrestricted J-statistic } & $2.80 \mathrm{E}-37$ \\
\hline Difference in J-stats & 5.777965 & \multicolumn{2}{|c|}{ Prob. (Difference in J-stats) } & 0.0556 \\
\hline \multicolumn{5}{|c|}{$C U M=\mathrm{C}(1)+\mathrm{C}(2) * G I N I$} \\
\hline \multicolumn{5}{|c|}{ Instrument specification: $T L U P O P$} \\
\hline \multicolumn{5}{|c|}{ Omitted variables: $R I R I R$} \\
\hline & Coefficient & Std. Error & $t$-Statistic & Prob. \\
\hline $\mathrm{C}(1)$ & -4.26751 & 3.412961 & -1.25038 & 0.2197 \\
\hline $\mathrm{C}(2)$ & 0.203838 & 0.082818 & 2.461277 & 0.0191 \\
\hline R-squared & 0.151228 & \multicolumn{2}{|c|}{ Adjusted R-squared } & 0.126264 \\
\hline$F$-Statistic & 6.057884 & \multicolumn{2}{|c|}{ Prob. $(F$-statistic $)$} & 0.019076 \\
\hline DW & 2.452886 & \multicolumn{2}{|c|}{ Restricted J-statistic } & 4.630676 \\
\hline & & \multicolumn{2}{|c|}{ Unrestricted J-statistic } & 0.000000 \\
\hline Difference in J-stats & 4.630676 & \multicolumn{2}{|c|}{ Prob. (Difference in J-stats) } & 0.0987 \\
\hline
\end{tabular}

The insignificant probability of the difference in J-stats at the $5 \%$ level of significance for each of three models (as shown in Table 8) reveals that the inclusion of $R I R$ and $I R$ will not change the J-stats significantly. This suggests that $R I R$ and $I R$ should be dropped for all the above three models, since an estimation of a TSLS method for duration, and cumulative loss on Gini index (where UPOP and TL are defined as instrumental variables) and an estimation of an OLS method for amplitude on Gini index will be sufficient to lead us to the unbiased results. 
Table 9 summarizes all these arguments and demonstrates the way in which the Gini index may affect the duration, amplitude and cumulative losses of the contractionary phase of cycles.

Table 9: Summary of Estimations

\begin{tabular}{|c|c|c|c|c|}
\hline & \multicolumn{4}{|c|}{ Gini Index Coefficients } \\
\hline & \multicolumn{2}{|c|}{ OLS Method } & \multicolumn{2}{c|}{ TSLS Method } \\
\hline & Coefficient & $p$-value & Coefficient & $p$-value \\
\hline $\boldsymbol{D U R}$ & 0.001434 & 0.8366 & $0.017793^{\mathrm{a}}$ & 0.0251 \\
\hline $\boldsymbol{A M P}$ & $0.26783^{\mathrm{b}}$ & 0.0007 & $0.26783^{\mathrm{b}}$ & 0.0007 \\
\hline $\boldsymbol{C U M}$ & 0.095401 & 0.2984 & $0.203838^{\mathrm{a}}$ & 0.0191 \\
\hline
\end{tabular}

${ }^{a}$ Statistically significant at $5 \%$ level of significance

${ }^{\mathrm{b}}$ Statistically significant at $1 \%$ level of significance

These results clearly show that a less equal income distribution (or a higher Gini index) will intensify the depth or amplitude of recessions by $0.26783 \%$ for one unit increase in the Gini index, regardless of whether the Gini index is considered an exogenous or endogenous variable. However, if the Gini index is assumed to be an endogenous variable (which economically makes more sense), a less equal income distribution is likely to increase the duration of cycles by $0.017793 \%$, and cumulative losses of recessions by $0.203838 \%$ for one unit increase in Gini index.

\subsection{Conclusion}

From the empirical results it would appear that a less equal income distribution leads to deeper and more costly recessions, given that the Gini index seems to be an endogenous variable. Overall, in this case, the length of the duration of contraction when going into a recession is longer and its amplitude deeper for countries with a less equal distribution of income. The results show that the decline of aggregate demands in the first phase of the cycles (cumulative income losses of GDP) is greater 
for countries experiencing a greater inequality of income. Given that we applied different empirical approach to investigate this effect, all these results are consistent with findings of previous chapter. 


\section{Chapter 6}

\section{INCOME DISTRIBUTION AND EXPANSIONS}

\subsection{Introduction}

In the preceding chapter we applied instrumental variable analysis along with an omitted variable test in order to examine the effect of income inequality as represented by the Gini index on the contractionary phase of business cycles. This effect was shown separately on duration and amplitude that jointly together form the cumulative loss of GDP as an economy enters into a recession. In this chapter, the aim is to focus on expansionary phases of the cycles using the same empirical approach to explore the possible relationship between income inequality and the intensity of expansion that a country may experience over time. This relationship may help us to understand how different level of income distribution in different countries can affect the cumulative gains of GDPs when the countries enter into recovery phase of business cycles.

\subsection{Empirical Investigation}

In this chapter we employ the same algorithm described in Chapter 3 to date the cycles of GDPs. In addition, in order to investigate the effect of the Gini index on the cumulative gain of GDPs in different countries, two separate methods of ordinary least squares (OLS) and two-staged least squares (TSLS) are employed, assuming that Urban Population (UPOP) and the Telephone Lines (TL) are instrumental variables (used to run the TSLS method), and the Real Interest Rate $(R I R)$ and 
Inflation Rate $(I R)$ are omitted variables from our structural models (OLS and TSLS). This demonstrates how income equality within the countries may play a role in increasing cumulative gains of countries when they actually are in expansionary phases of business cycles.

\subsubsection{Data Employed and Dating the Cycles}

We selected 36 countries $^{3}$ for which annual data on GDP in local currency units (in millions) are available for the 1970-2009 period. The data are from the World Development Indicators database of the World Bank (World Bank, 2011). Then these data are transformed to real local currency unit (based on year 2000). The data on Gini index values of countries are also collected from the World Bank ${ }^{4}$ for the years 1980 to 2009 . Given that the applied algorithm for dating the cycles calculates and presents a single average value for the cumulative gains of the cycles, for each individual country over the 1970 to 2009 period, for consistency we also calculate an average of the estimated Gini index values for each country. The assumption made is that the inaccessibility of the Gini index data for the years before 1980 for all the countries in the study, will not significantly invalidate our results, since the deviations of those data from the mean are assumed to be minor.

Moreover, to identify the peaks and troughs, we employ the concept of Expansion Terminating Sequence (ETS). The corresponding algorithm uses the rule that

\footnotetext{
${ }^{3}$ Argentina, Australia, Benin, Bolivia Brazil, Burundi, Canada, Chile, China, Congo. Rep, Denmark, France, Gabon, Gambia, Germany, Greece, Guinea, India, Ireland, Japan, Jordan, Kenya, Malaysia, Mexico, Morocco, New Zealand, Norway, Philippines, South Africa, Spain, Sweden, Tunisia, Turkey, United Kingdom, United States and Zambia.

${ }^{4}$ Data are based on primary household survey data obtained from government statistical agencies and World Bank country departments. Data for high-income economies are from the Luxembourg Income Study database. For more information and methodology please see PovcalNet (http://iresearch.worldbank.org/PovcalNet/jsp/index.jsp).
} 
requires an expansion to have at least two quarters of positive growth. Similar to contraction, to measure the expansion of a cycle it is necessary to focus on three measures of duration, amplitude and that cumulative gain (which is formed by both duration and amplitude). Further details are presented in Chapter 3. Measuring the duration, amplitude and cumulative gains of the cycles over the period of study for every single country allows us to run a separate regression model for duration, amplitude and cumulative gains of the cycles against the Gini index for further investigation.

\subsubsection{Model Specification}

To investigate the extent to which income inequality affects the expansion, the effect of the Gini index on each component of duration, amplitude and cumulative gain of the expansionary phase of a cycle is examined. A typical model is formed as follows:

$$
Y_{i}=\beta_{0}+\beta_{1} * \text { Gini }+\varepsilon_{i} \quad i=1,2,3,
$$

where $Y_{1}, Y_{2}$, and $Y_{3}$ represent duration $(D U R)$, amplitude $(A M P)$ and cumulative gain $(C U M)$, respectively, of the expansionary phase of cycles.

However, the endogeneity problem (existence of a correlation between the Gini index and $\varepsilon_{1}$ as an error term) may arise while estimating this model such that applying the OLS method will eventually produce a biased result (Bullock et al., 2010). To avoid such a problem, when the model suffers from an endogeneity problem, the application of instrumental variables may remedy this problem. These instrumental variables must satisfy two conditions in order to be considered reliable variables. The first mandatory condition is that there must be a strong correlation between each of the instrumental variables and the Gini index. In addition, no 
correlation between each of the instrumental variables and the residuals of the Equation $(6.1)\left(\varepsilon_{1}\right)$ must appear. Therefore to fulfill these conditions, similar to the preceding chapter, the two variables $U P O P$ and $T L$ are selected as instrumental variables for this model. The obtained estimators of the model

$$
G i n i=b_{0}+b_{1} * U P O P+b_{2} * T L+u_{1} \text {, }
$$

are significantly different from zero, and where R-squared (0.59) and $F$-statistics (24.138) are high enough to prove that the chosen instruments are not weak for this model (Stock et al., 2002) and satisfy the conditions reasonably well. Hence, Equation (6.1) could be transformed to

$$
Y_{i}=\beta_{0}^{*}+\beta_{1}^{*} * \hat{\operatorname{Gini}}+\varepsilon_{2 i}
$$

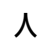

where the Gini is the predicted value from equation (6.2) and the TSLS method is used in order to obtain the estimators of this model (Foster \& McLanahan, 1996; Greene, 1993).

Given the selection of strong instrumental variables in Equation 6.2, a proper model needs to be selected in order to prevent estimating biased estimators. This can be done with the help of an endogeneity test to decide whether Equation 6.1 or Equation 6.3 is capable of producing the most reliable result. For this purpose, a Hausman test is conducted. As Hausman (1978) proposed, the exogenous Gini index requires no correlation between the error term in Equation 6.2 and the dependent variable of Equation 6.1. In this case, the instrumental variables should be omitted to obtain more accurate results. For the endogeneity test, an OLS method is first conducted for Equation 6.2. Then, its error term is used as an explanatory variable for Equation 6.1. 
Finally, the estimation of the following equation using the OLS method reveals that whether Gini is an exogenous or an endogenous variable.

$$
Y_{i}=\varphi_{0}+\varphi_{1} * \text { Gini }+\delta * u_{1}+\varepsilon_{3 i}
$$

If the null hypothesis as $\delta=0$ is not rejected we can safely conclude that the Gini index is an exogenous variable. Therefore, the estimation of Equation 6.1 is sufficient to produce an unbiased result. However, if we reject the null hypothesis (i.e., if $\delta$ becomes statistically significant), the Gini index is considered an endogenous variable. In this case, Equation 6.3 must be estimated to produce a reliable and unbiased result. Table10 presents the results of endogeneity tests on Equation 6.4 which clearly show that the Gini index is an exogenous variable at the 5 percent level of significance, since the residuals of Equation $6.2(R E S)$ are not significantly related to the duration, amplitude and cumulative gains. This leads us to ensure that the estimation of Equation 6.1 using the OLS method will produce an unbiased result. 
Table 10: Endogeneity Test Results

\begin{tabular}{|c|c|c|c|c|}
\hline \multicolumn{5}{|c|}{$D U R=\mathrm{C}(1)+\mathrm{C}(2) * G I N I+\mathrm{C}(3) * R E S$} \\
\hline Variable & Coefficient & Std. Error & $t$-Statistic & Prob. \\
\hline GINI & -0.219248 & 0.098726 & -2.220762 & 0.0333 \\
\hline RES & 0.269485 & 0.194939 & 1.739300 & 0.1113 \\
\hline $\mathrm{C}$ & 14.90681 & 4.029345 & 3.699562 & 0.0008 \\
\hline R-squared & 0.143991 & \multicolumn{2}{|c|}{ Adjusted R-squared } & 0.081576 \\
\hline Prob. $(F$-statistics $)$ & 0.093018 & \multicolumn{2}{|c|}{ DW } & 2.093370 \\
\hline \multicolumn{5}{|c|}{$A M P=\mathrm{C}(1)+\mathrm{C}(2)^{*} G I N I+\mathrm{C}(3) * R E S$} \\
\hline Variable & Coefficient & Std. Error & $t$-Statistic & Prob. \\
\hline GINI & -0.718329 & 0.519024 & -1.384001 & 0.1756 \\
\hline$R E S$ & 1.073456 & 0.814543 & 1.317863 & 0.1966 \\
\hline $\mathrm{C}$ & 55.65776 & 21.18303 & 2.627469 & 0.0130 \\
\hline R-squared & 0.063444 & \multicolumn{2}{|c|}{ Adjusted R-squared } & 0.006683 \\
\hline Prob. $(F$-statistics $)$ & 0.339085 & \multicolumn{2}{|c|}{ DW } & 1.782474 \\
\hline \multicolumn{5}{|c|}{$C U M=\mathrm{C}(1)+\mathrm{C}(2) * G I N I+\mathrm{C}(3) * R E S$} \\
\hline Variable & Coefficient & Std. Error & $t$-Statistic & Prob. \\
\hline GINI & 3.567547 & 1.088941 & 3.276161 & 0.0024 \\
\hline$R E S$ & -1.609877 & 7.863355 & -0.204732 & 0.8390 \\
\hline R-squared & -0.036377 & \multicolumn{2}{|c|}{ Adjusted R-squared } & -0.066859 \\
\hline Prob. $(F$-statistics $)$ & NA & \multicolumn{2}{|c|}{ DW } & 1.606052 \\
\hline
\end{tabular}

However, we might have excluded some other variables from our model that significantly may affect the average duration, amplitude and cumulative gains of the expansionary phase of cycles. As King et al. (1994) observed, if "relevant variables are omitted, our ability to estimate causal inferences correctly is limited". Therefore, conducting an omitted variable test is required to prevent the occurrence of such a bias. In practice, finding some variables that affect the expansionary phase of business cycles is necessary such that those variables, if included in Equation 6.1, will change the result. In theory the rate of productivity and the real interest rate, (RIR), are two variables that they have the greatest effect on business cycles. However, due to lack of reliable data on the rate of productivity for the selected countries between 1970 and 2009, real interest rate, $(R I R)$, and inflation rate, $(I R)$, are chosen for the omitted variable test. The data for these two variables are from World Bank database (World Bank, 2012). 
Thus, the omitted variable test is conducted to see whether the inclusion of $R I R$ and $I R$ significantly changes the results. Table 11 shows the estimation results of Equation 6.1, assuming that the Gini index is an exogenous variable, RIR and $I R$ are omitted variables. 
Table 11: Omitted Variable Test for the Model in Equation 6.1

\begin{tabular}{|c|c|c|c|c|}
\hline \multicolumn{5}{|c|}{$D U R=\mathrm{C}(1)+\mathrm{C}(2) * G I N I+\mathrm{C}(3) * R I R+\mathrm{C}(4) * I R($ Omitted Variables: $R I R I R)$} \\
\hline$F$-Statistic & 0.597473 & \multicolumn{2}{|c|}{ Prob. (F-Statistics) } & 0.5562 \\
\hline Likelihood Ratio & 1.319821 & \multicolumn{2}{|c|}{ Prob. (Likelihood) } & 0.5169 \\
\hline & Coefficient & Std. Error & $t$-Statistic & Prob. \\
\hline $\mathrm{C}$ & 8.902780 & 3.667001 & 2.427810 & 0.0210 \\
\hline Gini & -0.056475 & 0.093492 & -0.604068 & 0.5501 \\
\hline$R I R$ & -0.038668 & 0.123127 & -0.314050 & 0.7555 \\
\hline$I R$ & -0.007478 & 0.011243 & -0.665117 & 0.5107 \\
\hline R-squared & 0.088705 & \multicolumn{2}{|c|}{ Adjusted R-squared } & 0.003271 \\
\hline$F$-Statistic & 1.038288 & \multicolumn{2}{|c|}{ Prob. (F-Statistics) } & 0.388870 \\
\hline DW & 2.146817 & & & \\
\hline \multicolumn{5}{|c|}{$A M P=\mathrm{C}(1)+\mathrm{C}(2) * G I N I+\mathrm{C}(3) * R I R+\mathrm{C}(4) * I R($ Omitted Variables: $R I R I R)$} \\
\hline$F$-Statistic & 0.717325 & \multicolumn{2}{|c|}{ Prob. (F-Statistics) } & 0.4957 \\
\hline Likelihood Ratio & 1.578848 & \multicolumn{2}{|c|}{ Prob. (Likelihood) } & 0.4541 \\
\hline & Coefficient & Std. Error & $t$-Statistic & Prob. \\
\hline $\mathrm{C}$ & 29.90859 & 18.86227 & 1.585631 & 0.1227 \\
\hline Gini & 0.007109 & 0.480901 & 0.014783 & 0.9883 \\
\hline$R I R$ & -0.322482 & 0.633338 & -0.509178 & 0.6141 \\
\hline$I R$ & -0.033599 & 0.057832 & -0.580983 & 0.5653 \\
\hline R-squared & 0.056455 & \multicolumn{2}{|c|}{ Adjusted R-squared } & -0.032002 \\
\hline$F$-Statistic & 0.638221 & \multicolumn{2}{|c|}{ Prob. (F-Statistics) } & 0.595951 \\
\hline DW & 1.835810 & & & \\
\hline \multicolumn{5}{|c|}{$C U M=\mathrm{C}(1)+\mathrm{C}(2) * G I N I+\mathrm{C}(3) * R I R+\mathrm{C}(4) * I R$ (Omitted Variables: $R I R I R)$} \\
\hline$F$-Statistic & 1.124528 & \multicolumn{2}{|c|}{ Prob. (F-Statistics) } & 0.3373 \\
\hline Likelihood Ratio & 2.445232 & \multicolumn{2}{|c|}{ Prob. (Likelihood) } & 0.2945 \\
\hline & Coefficient & Std. Error & $t$-Statistic & Prob. \\
\hline $\mathrm{C}$ & 199.5659 & 223.9433 & 0.891145 & 0.3795 \\
\hline Gini & 0.379695 & 5.709522 & 0.066502 & 0.9474 \\
\hline$R I R$ & -9.819739 & 7.519341 & -1.305931 & 0.2009 \\
\hline$I R$ & 0.114399 & 0.686608 & 0.166615 & 0.8687 \\
\hline R-squared & 0.071753 & \multicolumn{2}{|c|}{ Adjusted R-squared } & -0.015270 \\
\hline$F$-Statistic & 0.824530 & \multicolumn{2}{|c|}{ Prob. (F-Statistics) } & 0.490077 \\
\hline DW & 1.775078 & & & \\
\hline
\end{tabular}

In this model, the result of the $F$-test shows that the independent variables are not jointly significant at the 5 percent level for none of the duration, amplitude and cumulative gain of cycles. Hence, the conclusion is that the exclusion of RIR and IR from the model will not affect the final result. Given that the Gini is an exogenous variable at the 10 percent level of significance as shown in Table 10, eventually, the 
estimation of Equation 6.1 using the OLS method is quite sufficient to produce a solid result for our analysis. The result is shown in Table 12 below.

Table 12: Summary of Estimations

\begin{tabular}{|l|c|c|}
\hline \multicolumn{3}{|c|}{ Gini Index Coefficients (OLS Method) } \\
\hline \multicolumn{2}{|l|}{} \\
\hline $\boldsymbol{D U R}$ & Coefficient & $p$-value \\
\hline $\boldsymbol{A M P}$ & -0.109832 & 0.1699 \\
\hline $\boldsymbol{C U M}$ & -0.282485 & 0.4895 \\
\hline & -2.293800 & 0.6399 \\
\hline
\end{tabular}

The negative sign of the coefficients for all three models indicate that equality of income distribution within the countries is associated with a longer duration, deeper amplitude, and hence a greater cumulative gain of the expansionary phase of business cycles. However, none of these coefficients are statistically significant at the 5 percent or even 10 percent level of significance. This deprives us of a solid conclusion on the possible relationship between income equality and cumulative gain in the expansionary phase of the cycles.

\subsection{Conclusion}

Although none of these results are statistically significant, preventing us from drawing a definite conclusion, however, the sign of the coefficients estimated by suggest that the duration of expansionary phases of business cycles seems longer; its amplitude seems deeper and hence the cumulative gains seems greater for the countries with less inequality of income, given that the Gini index is shown to be an exogenous variable. These results are consistent with the findings in Chapter 4 even though a different empirical approach was undertaken. Overall, we can firmly 
conclude that a more equal income distribution not only prevents a costly recession, as compared to the countries with a less equal income distribution, it is more likely that the expansion phase of the business cycle seems more fruitful. Hence, while it is the case that a more equal income distribution is desirable for many social reasons, these results add one more argument in support of policies that would improve the distributions of income within countries over time. 


\section{Chapter 7}

\section{CONCLUSION}

The study was set out to explore a relationship between the level of income distribution within 36 selected countries and the degree of intensity of business cycles experienced by those countries over 40 years time period. The study has also sought whether the equality of income distribution within the countries has any impact on the number of business cycles experienced over the same time span. The main arguments of this study are presented in chapter 4,5 and 6. The findings of this work are examined by two different empirical approaches, namely, correlations along with a $t$-test, and application of OLS and TSLS methods.

The discussions under chapter 4 are allocated to find a possible relationship between the degree of income inequality and the severity of contractionary (CTS) and expansionary (ETS) phases of cycles in GDP, consumption and investment, shown as the duration and depth of recessions/expansions for the countries under study. To identify true cycles that affect GDPs followed by consumptions and investments, we employ the algorithm proposed by Harding and Pagan (1999) to date the cycles of GDPs, consumptions and investments. After the dating the cycles, a correlation between duration, amplitude and cumulative losses of cycles and the Gini index of those countries along with a respective $t$-test for each set of correlations shows that a less equal income distribution leads to deeper and more 
costly recessions. Overall, the duration of contraction phase of the cycles when going into a recession is longer for countries with a less equal distribution of income which results in a greater cumulative income losses of GDP. In this regard, the estimation shows that during the recession period (CTS), the cumulative loss in cycles of consumption is greater than that of investment for the countries with a more income inequality. This leads us to conclude that during the recession, consumption in countries with greater income inequality plays a greater role in pulling the economy down compared to investment, while for the countries with less income inequality, consumption alleviates the effects of recession to prevent GDP from entering deeper recession. However, while the sign of correlations between duration of expansionary phase of cycles in GDP show that the speed of recovery is somewhat faster, this effect is not statistically significant.

In addition, assuming that the trends of GDP, consumption and investment follow a random walk with a drift model, the number of cycles in all three variables was calculated. Then, a correlation between the number cycles in GDP, consumption and investment and the Gini index of countries revealed that a higher level of income inequality will lead to a higher number of cycles in GDP and consumption. However, this conclusion cannot be drawn as clearly for investment.

The discussions in chapter 5 is based on more advanced empirical methods to confirm the findings of chapter 4 on the relationship between income inequality and the degree of severity of recessions (CTS) experienced by the countries over the same time span. This effect was shown separately on duration and amplitude that 
jointly together form the cumulative loss of GDP as an economy enters into a recession. Therefore after identifying the cycles of GDPs for the selected countries, we examine both ordinary least squares (OLS) and two-staged least squares (TSLS) methods with a series of tests to identify the most possible unbiased results. To carry out both methods, it is assumed that real interest rate (RIR) and the inflation rates (IR) are omitted variables. To estimate the TSLS method, urban population (UPOP) and telephone line (TL), are chosen as instrumental variables.

From the empirical results it would appear that a less equal income distribution leads to deeper and more costly recessions, given that the Gini index seems to be an endogenous variable. Overall, in this case, the length of the duration of contraction when going into a recession is longer and its amplitude deeper for countries with a less equal distribution of income. The results show that the decline of aggregate demands in the first phase of the cycles (cumulative income losses of GDP) is greater for countries experiencing a greater inequality of income.

Given that a different empirical approach is applied to investigate this effect, all these results are consistent with findings of previous chapter.

A set of economic rationales is presented to explain why countries with greater income inequality will tend to have deeper and more costly recessions. These were four components of aggregate demand that move during a recession; namely consumption, investment, net exports and governmental spending. 
In chapter 6, the aim is to focus on expansionary phases of the cycles using the same empirical approach employed in chapter 5 to explore the possible relationship between income inequality and the intensity of expansion that a country may experience over time. This effect was again shown separately on duration and amplitude that jointly together form the cumulative gain of GDP as an economy enters into recovery.

Although none of these results are statistically significant, preventing us from drawing a definite conclusion, however, the sign of the coefficients estimated suggest that the duration of expansionary phases of business cycles seems longer; its amplitude seems deeper and hence the cumulative gains seems greater for the countries with less inequality of income. These results are somewhat consistent with the findings in Chapter 4 even though a different empirical approach was undertaken. Overall, we can firmly conclude that a more equal income distribution not only reduces a costly recession, it might result in a more rapid expansionary phase during the recovery. Hence, while it is the case that a more equal income distribution is desirable for many social reasons, these results add one more argument in support of policies that would improve the distributions of income within countries over time. 


\section{REFERENCES}

Aizenman, J. and Jinjarak, Y. (2012) Income inequality, tax base and sovereign spreads, NBER Working Paper No. w18176. Available at http://ssrn.com/abstract=2089248 (accessed October 2013).

Alesina, A. and Rodrik, D. (1994) Distributive politics and economic growth, Quarterly Journal of Economics, 109, 465-90.

Alpizar, F., Carlsoson, F. and Johansson, S. (2005) How much do we care about absolute versus relative income and consumption?, Journal of Economic Behavior and Organization, 56, 405-21.

Amorosi, G., Gosling A., and Ledesma M.L. (2012) Income distribution, household heterogeneity and consumption insurance in the UK: a mixture model approach, Paper Presented at RES 2012 conference, University of Cambridge.

Antzoulatos, A. (2012) Policy Responses to the European Debt Crisis Treating the 'Symptoms' or the 'Disease'?, Panoeconomicus, 59(4): 529-552.

Arthur C. Pigu, (1920) The Economics of Welfare, Economic Journal 48: 63541.

Assane, J. and Grammy, A. (2003) An assessment of the growth and inequality causality relationship, Applied Economic Letters, 10, 871-87. 
Athanasopoulos, G. and Vahid, F. (2001) Capturing the shape of the business cycle with autoregressive leading indicator models, Econpapers. Available at http://www.buseco.monash.edu.au/ebs/pubs/wpapers/2001/wp7-01.pdf (accessed 21 September 2011).

Atkinson A.B., and Bourguignon F. (2000), University of Cambridge, Cambridge UK, Elsevier, Handbook of Income Distribution with number 1

Bengoa, M. and Sanchez-Roblez, B. (2005) Does equality reduce growth?, Applied Economic Letters, 12, 479-83.

Berg, A., Jonathan .D, O. and Zettelmeyer, J. (2012), What Makes Growth Sustained?, Journal of Development Economics, 98(2), 149-66.

Bernanke, B. S. (1983) Irreversibility, Uncertainty, and Cyclical Investment, Quarterly Journal of Economics, 14: 85-106.

Birdsall, N. (2007) Income distribution: effects on growth and development, International Handbook of Development, 2, 6-45. Available at http://EconPapers.repec.org/RePEc:cgd:wpaper:118 (accessed 17 October 2011).

Bishop, A., Formby, J. P. and Smith, W. J. (1997) Demographic change and income inequality in the United States, 1976-1989, Southern Economic Journal, 64, $34-44$ 
Bloom, N., Bond S., and Reenen J.V. (2007), Uncertainty and Investment Dynamics, Review of Economic Studies, 74 (2): 391-415.

Burkhauser, R., Crews, A., Mary, C. and Jenkins, S. (1999) Testing the significance of income distribution changes over the 1980s business cycle: A cross-national comparison, Journal of Applied Econometrics, 14, 253-72.

Bullock, J. G., Green, D. P. and Ha, S. E. (2010) Yes, but what is the mechanism? (Don't expect an easy answer), Journal of Personality and Social Psychology, $98,550-58$.

Burns, A. F. och W. C. Mitchell, (1946), Measuring Business Cycles, NBER, New York.

Caruana, A., Ewing, M. T. and Ramaseshan, B. (2000) Effects of economic recession on export activity, Journal of Global Marketing, 13, 93-106.

Clarke, G. (1995) More evidence on income distribution and growth, Journal of Development Economics, 47, 403-27.

Cogley, T., and Nason J.M., (1995) Output Dynamics in Real-Business-Cycle Models, American Economic Review, 85: 492-511. 
Dadkhah, K. M. (2006) Income distribution and economic growth in the United States: 1947 2001. Available atwww.tcnj.edu/ business/economics/documents/ heyse.thesis.tcnj.pdf (accessed 22 December 2011).

Dellas, H., and P. Sakellaris (2003) On the Cyclicality of Schooling: Theory and Evidence, Oxford Economic Papers, 55(1), 148-172.

Duesenberry, J. S. (1948) Income-consumption relations and their implications, in Income, Employment and Public Policy, (Eds) L. Metzler et al., W.W.Norton \& Company, Inc., New York.

Foster, E. M. and McLanahan, S. (1996) An illustration of the use of instrumental variables: Do neighborhood conditions affect a young person's chance of finishing high school? Psychological Methods, 1, 249-60.

Frazer, G. (2006) Inequality and Development Across and Within Countries, World Development, 34(9): 1459-1481.

Friedman, M., (1956) A Theory of the Consumption Function, Princeton University Press, Princeton.

Friedman, M. and Schwartz A. J. (1963) A Monetary History of the United States 1867-1960. Princeton: Princeton University Press for NBER.

Greene, W. (1993) Econometric analysis, 2nd edn, Macmillan, New York. 
Hansen, L. P. (1982) Large sample properties of generalised method of moments estimators, Econometrica, 50, 1029-54.

Josifidis, K., Lošonc A., and Supić N. (2010) Neoliberalism: Befall or Respite?, Panoeconomicus, 57: 101-117.

Harding, D., and Pagan A. (1999) Knowing the Cycle, Econpapers, http://melbourneinstitute.com/wp/wp1999n12.pdf (accessed 2011/06/17).

Harding, D. and Pagan, A. R. (2002) Dissecting the cycle, Journal of Monetary Economics, 49, 365-81.

Hausman, J. A. (1978) Specification tests in econometrics, Econometrica, 46, 125171.

Helpman, E. and P. Krugman (1985), Market Structure and International Trade. MIT Press.

Holland, S., Ott S.H., and Riddiough T. (2000) The Role of Uncertainty in Investment: an Examination of Competing Investment Models Using Commercial Real Estate Dada, Real Estate Economics, 28(1) :33-64.

Hoover, G. A., Giedeman D.C., and Dibooglu S. (2009) Income Inequality and the Business Cycle Economic Systems, 33(3): 278-292. 
Keynes, J. M. (1936) The General Theory of Employment, Interest, and Money, Macmillan, London.

King, G., Keohane, R. O. and Verba, S. (1994) Designing social inquiry: Scientific inference in qualitative research, Princeton University Press, Princeton, NJ.

Krebs, T. (2003) Human Capital Risk and Economic Growth, Quarterly Journal of Economics, 118(2), 709-744.

Krugman, (1981) International Trade and Income Distribution: A Reconsideration, National Bureau of Economic Research, NBER Working Papers 0356.

Kuznets, S. (1946) National Product Since 1869, National Bureau of Economic Research, New York.

Kuznets, S. (1955) Economic growth and income inequality, American Economic Review, 34, 1-28.

Maliar, L., Maliar S., and Mora J. (2005) Income and Wealth Distributions along the Business Cycle: Implications from the Neoclassical Growth Model, The B.E. Journal of Macroeconomics, 5(1): 15.

Ondrich, J., Richardson, J. D. and Zhang, S. (2006) A further investigation of the link between trade and income, International Economic Journal, 20, 19-36. 
Palley, T. I. (2010) The Relative Permanent Income Theory of Consumption: A Synthetic Keynes-Duesenberry-Friedman Model, Review of Political Economy, 1, 41-56.

Persson, T. and Tabellini ,G. (1994) Is inequality harmful for growth?, American Economic Review, 84, 600-21.

Ricardo, D. (1911), Principles of Political Economy and Taxation, Edited, with Introduction Essay, Notes and Appendices, by E.C.K. Gonner, M.A., London; G. Bell and Sons Ltd.

Lionel Robbins (1938), Interpersonal Comparisons of Utility A Comment, Economic Journal 48: 635-41

Sargan, J. D. (1958) The estimation of economic relationships using instrumental variables, Econometrica, 26, 393-415.

Sakellaris, P., and A. Spilimbergo (2000): Business Cycles and Investment in Human Capital: International Evidence on Higher Education," Carnegie Rochester Conference Series on Public Policy, 52(1), 221-256.

Samuelson (1947), Foundations of Economic Analysis, Cambridge, Mass.: Harvard University Ress, p. 225. 
Stein, L. C.D., and Stone E.C. (2012) The Effect of Uncertainty on Investment, Hiring, and R\&D: Causal Evidence from Equity Options, Stanford University.

Strebulaev, I. A., Zhu H., and Zryumov P.(2012) Dynamic Information Asymmetry, Financing and Investment Decisions, Working Paper. www.mit.edu/ zhuh/SZZ_DynamicMM.pdf(accessed 2014/05/04)

Stock, J. H., Wright, J. H. and Yogo, M. (2002) A survey of weak instruments and weak identification in generalized method of moments, Journal of Business and Economic Statistics, 4, 518-529.

Sun, P., Sen, S. and Jin, S. (2013) Equity market liberalization, credit constraints and income inequality, Economics - The Open-Access, Open-Assessment EJournal, Kiel Institute for the World Economy, 7, 1-28.

Tanninen, H. (1999) Income inequality, government expenditures and growth, Applied Economics, 31, 1109-17.

Wei, M. (2003): "Human Capital, Business Cycles and Asset Pricing,” Manuscript, Columbia University.

World Bank (2011) World Development Indicators Online (WDI) database. Available at: http://data.worldbank.org/data-catalog/world-developmentindicators (accessed 27 February 2011). 
World Bank (2012) World Development Indicators Online (WDI) database. Available at: http://data.worldbank.org/data-catalog/world-developmentindicators (accessed 15 December 2012).

Yan, B. (2007) International trade as determined by income and income distribution, International Economic Journal, 21, 633-651. 
APPENDICES 


\section{Appendix A: OLS Estimation of GDPs}

Dependent Variable: LOG(ARG)

Method: Least Squares

Date: 03/10/11 Time: 12:32

Sample: 117

Included observations: 17

\begin{tabular}{lrlrr}
\hline \hline \multicolumn{1}{c}{ Variable } & Coefficient & \multicolumn{1}{c}{ Std. Error } & t-Statistic & Prob. \\
\hline \multicolumn{1}{c}{ C } & 3.615894 & 2.284579 & 1.582740 & 0.1358 \\
\multicolumn{1}{c}{ LOG(ARG1) } & 0.456563 & 0.253421 & 1.801600 & 0.0932 \\
\multicolumn{1}{c}{ LOG(ARG2) } & 0.313536 & 0.093394 & 3.357127 & 0.0047 \\
\hline \hline R-squared & 0.861987 & Mean dependent var & 12.58925 \\
Adjusted R-squared & 0.842271 & S.D. dependent var & 0.159751 \\
S.E. of regression & 0.063445 & Akaike info criterion & -2.518492 \\
Sum squared resid & 0.056354 & Schwarz criterion & -2.371454 \\
Log likelihood & 24.40718 & Hannan-Quinn criter. & -2.503876 \\
F-statistic & 43.71988 & Durbin-Watson stat & 0.390551 \\
Prob(F-statistic) & 0.000001 & & \\
\hline \hline
\end{tabular}

Dependent Variable: LOG(AUS)

Method: Least Squares

Date: 03/10/11 Time: 12:44

Sample (adjusted): 144

Included observations: 44 after adjustments

\begin{tabular}{lrlrr}
\hline \hline \multicolumn{1}{c}{ Variable } & Coefficient & \multicolumn{1}{c}{ Std. Error } & t-Statistic & Prob. \\
\hline \hline \multicolumn{1}{c}{ C } & 0.465337 & 0.078050 & 5.962063 & 0.0000 \\
LOG(AUS1) & 0.804412 & 0.022405 & 35.90365 & 0.0000 \\
\multicolumn{1}{c}{ LOG(AUS2) } & 0.218673 & 0.026330 & 8.305231 & 0.0000 \\
\hline \hline R-squared & 0.998691 & Mean dependent var & 12.94578 \\
Adjusted R-squared & 0.998627 & S.D. dependent var & 0.423405 \\
S.E. of regression & 0.015690 & Akaike info criterion & -5.405828 \\
Sum squared resid & 0.010093 & Schwarz criterion & -5.284179 \\
Log likelihood & 121.9282 & Hannan-Quinn criter. & -5.360715 \\
F-statistic & 15636.15 & Durbin-Watson stat & 0.803510 \\
Prob(F-statistic) & 0.000000 & & \\
\hline \hline
\end{tabular}


Dependent Variable: LOG(BEN)

Method: Least Squares

Date: 03/10/11 Time: 12:46

Sample (adjusted): 124

Included observations: 24 after adjustments

\begin{tabular}{lrlrr}
\hline \hline \multicolumn{1}{c}{ Variable } & Coefficient & \multicolumn{1}{c}{ Std. Error } & t-Statistic & Prob. \\
\hline \multicolumn{1}{c}{ C } & -0.692239 & 0.337601 & -2.050467 & 0.0530 \\
LOG(BEN1) & 0.995691 & 0.039210 & 25.39409 & 0.0000 \\
\multicolumn{1}{c}{ LOG(BEN2) } & 0.075193 & 0.022505 & 3.341161 & 0.0031 \\
\hline \hline R-squared & 0.993277 & Mean dependent var & 14.02230 \\
Adjusted R-squared & 0.992636 & S.D. dependent var & 0.268302 \\
S.E. of regression & 0.023024 & Akaike info criterion & -4.588121 \\
Sum squared resid & 0.011132 & Schwarz criterion & -4.440864 \\
Log likelihood & 58.05745 & Hannan-Quinn criter. & -4.549053 \\
F-statistic & 1551.195 & Durbin-Watson stat & 1.286335 \\
\hline \hline
\end{tabular}

Dependent Variable: LOG(BOL)

Method: Least Squares

Date: 03/10/11 Time: 12:51

Sample (adjusted): 136

Included observations: 36 after adjustments

\begin{tabular}{lcccc}
\hline \hline \multicolumn{1}{c}{ Variable } & Coefficient & Std. Error & t-Statistic & Prob. \\
\hline \multicolumn{1}{c}{ C } & 0.287899 & 0.040729 & 7.068626 & 0.0000 \\
LOG(BOL1) & 0.985677 & 0.010323 & 95.48154 & 0.0000 \\
\multicolumn{1}{c}{ LOG(BOL2) } & 0.015919 & 0.012246 & 1.299957 & 0.2026 \\
\hline \hline R-squared & 0.999299 & Mean dependent var & 7.158241 \\
Adjusted R-squared & 0.999256 & S.D. dependent var & 4.399394 \\
S.E. of regression & 0.119966 & Akaike info criterion & -1.323562 \\
Sum squared resid & 0.474931 & Schwarz criterion & -1.191602 \\
Log likelihood & 26.82411 & Hannan-Quinn criter. & -1.277504 \\
F-statistic & 23518.14 & Durbin-Watson stat & 1.493339 \\
\hline \hline
\end{tabular}


Dependent Variable: LOG(BRA)

Method: Least Squares

Date: 03/10/11 Time: 12:56

Sample: 122

Included observations: 22

\begin{tabular}{lrlrr}
\hline \hline \multicolumn{1}{c}{ Variable } & Coefficient & \multicolumn{1}{c}{ Std. Error } & t-Statistic & Prob. \\
\hline \multicolumn{1}{c}{ C } & 0.671826 & 0.076935 & 8.732390 & 0.0000 \\
LOG(BRA1) & 0.778447 & 0.095736 & 8.131149 & 0.0000 \\
\multicolumn{1}{c}{ LOG(BRA2) } & 0.229509 & 0.100066 & 2.293587 & 0.0334 \\
\hline \hline R-squared & 0.999873 & Mean dependent var & 12.29196 \\
Adjusted R-squared & 0.999860 & S.D. dependent var & 3.731021 \\
S.E. of regression & 0.044199 & Akaike info criterion & -3.274119 \\
Sum squared resid & 0.037117 & Schwarz criterion & -3.125341 \\
Log likelihood & 39.01531 & Hannan-Quinn criter. & -3.239071 \\
F-statistic & 74811.87 & Durbin-Watson stat & 1.385208 \\
Prob(F-statistic) & 0.000000 & & \\
\hline \hline
\end{tabular}

Dependent Variable: LOG(BUR)

Method: Least Squares

Date: 03/10/11 Time: 13:02

Sample (adjusted): 146

Included observations: 46 after adjustments

\begin{tabular}{lrlrr}
\hline \hline \multicolumn{1}{c}{ Variable } & Coefficient & \multicolumn{1}{c}{ Std. Error } & t-Statistic & Prob. \\
\hline \multicolumn{1}{c}{ C } & 0.445659 & 0.288249 & 1.546089 & 0.1294 \\
LOG(BUR1) & 0.948996 & 0.032933 & 28.81636 & 0.0000 \\
LOG(BUR2) & 0.032035 & 0.017414 & 1.839586 & 0.0727 \\
\hline \hline R-squared & 0.985565 & Mean dependent var & 12.90953 \\
Adjusted R-squared & 0.984894 & S.D. dependent var & 0.374893 \\
S.E. of regression & 0.046077 & Akaike info criterion & -3.253992 \\
Sum squared resid & 0.091295 & Schwarz criterion & -3.134732 \\
Log likelihood & 77.84181 & Hannan-Quinn criter. & -3.209316 \\
F-statistic & 1467.933 & Durbin-Watson stat & 1.149075 \\
Prob(F-statistic) & 0.000000 & & \\
\hline \hline
\end{tabular}


Dependent Variable: LOG(CAN)

Method: Least Squares

Date: 03/10/11 Time: 13:04

Sample (adjusted): 140

Included observations: 40 after adjustments

\begin{tabular}{lrlrr}
\hline \hline \multicolumn{1}{c}{ Variable } & Coefficient & \multicolumn{1}{c}{ Std. Error } & t-Statistic & Prob. \\
\hline \multicolumn{1}{c}{ C } & 0.959249 & 0.096816 & 9.908007 & 0.0000 \\
LOG(CAN1) & 0.788170 & 0.023776 & 33.14998 & 0.0000 \\
\multicolumn{1}{c}{ LOG(CAN2) } & 0.197752 & 0.026745 & 7.394052 & 0.0000 \\
\hline \hline R-squared & 0.997930 & Mean dependent var & 13.55988 \\
Adjusted R-squared & 0.997818 & S.D. dependent var & 0.334584 \\
S.E. of regression & 0.015628 & Akaike info criterion & -5.407451 \\
Sum squared resid & 0.009037 & Schwarz criterion & -5.280785 \\
Log likelihood & 111.1490 & Hannan-Quinn criter. & -5.361653 \\
F-statistic & 8919.309 & Durbin-Watson stat & 0.765387 \\
\hline \hline
\end{tabular}

Dependent Variable: LOG(CHI)

Method: Least Squares

Date: 03/10/11 Time: 13:10

Sample: 145

Included observations: 45

\begin{tabular}{lrlrr}
\hline \hline \multicolumn{1}{c}{ Variable } & Coefficient & \multicolumn{1}{c}{ Std. Error } & t-Statistic & Prob. \\
\hline \hline \multicolumn{1}{c}{ C } & 0.420958 & 0.254312 & 1.655279 & 0.1053 \\
LOG(CHI1) & 0.639340 & 0.055223 & 11.57745 & 0.0000 \\
\multicolumn{1}{c}{ LOG(CHI2) } & 0.392614 & 0.039703 & 9.888858 & 0.0000 \\
\hline \hline R-squared & 0.998853 & Mean dependent var & 14.97056 \\
Adjusted R-squared & 0.998798 & S.D. dependent var & 1.145205 \\
S.E. of regression & 0.039700 & Akaike info criterion & -3.550600 \\
Sum squared resid & 0.066195 & Schwarz criterion & -3.430156 \\
Log likelihood & 82.88850 & Hannan-Quinn criter. & -3.505699 \\
F-statistic & 18285.79 & Durbin-Watson stat & 0.789246 \\
Prob(F-statistic) & 0.000000 & & \\
\hline \hline
\end{tabular}


Dependent Variable: LOG(CHIL)

Method: Least Squares

Date: 03/10/11 Time: 13:12

Sample: 150

Included observations: 50

\begin{tabular}{lcccc}
\hline \hline \multicolumn{1}{c}{ Variable } & Coefficient & \multicolumn{1}{c}{ Std. Error } & t-Statistic & Prob. \\
\hline \multicolumn{1}{c}{ C } & 0.642354 & 0.059358 & 10.82166 & 0.0000 \\
LOG(CHIL1) & 0.752114 & 0.033013 & 22.78269 & 0.0000 \\
\multicolumn{1}{c}{ LOG(CHIL2) } & 0.253545 & 0.031961 & 7.932993 & 0.0000 \\
\hline \hline R-squared & 0.999868 & Mean dependent var & 14.47497 \\
Adjusted R-squared & 0.999863 & S.D. dependent var & 4.128211 \\
S.E. of regression & 0.048402 & Akaike info criterion & -3.160426 \\
Sum squared resid & 0.110109 & Schwarz criterion & -3.045705 \\
Log likelihood & 82.01065 & Hannan-Quinn criter. & -3.116740 \\
F-statistic & 178199.2 & Durbin-Watson stat & 0.875565 \\
\hline \hline
\end{tabular}

Dependent Variable: LOG(CONG)

Method: Least Squares

Date: 03/10/11 Time: 13:16

Sample: 136

Included observations: 36

\begin{tabular}{lrlrr}
\hline \hline \multicolumn{1}{c}{ Variable } & Coefficient & \multicolumn{1}{c}{ Std. Error } & t-Statistic & Prob. \\
\hline \hline \multicolumn{1}{c}{ C } & -1.422216 & 2.072717 & -0.686160 & 0.4974 \\
\multicolumn{1}{c}{ LOG(CONG1) } & 0.618691 & 0.147013 & 4.208418 & 0.0002 \\
LOG(CONG2) & 0.564582 & 0.099208 & 5.690920 & 0.0000 \\
\hline \hline R-squared & 0.675159 & Mean dependent var & 14.45200 \\
Adjusted R-squared & 0.655472 & S.D. dependent var & 0.359185 \\
S.E. of regression & 0.210829 & Akaike info criterion & -0.195884 \\
Sum squared resid & 1.466812 & Schwarz criterion & -0.063924 \\
Log likelihood & 6.525905 & Hannan-Quinn criter. & -0.149826 \\
F-statistic & 34.29406 & Durbin-Watson stat & 0.630565 \\
Prob(F-statistic) & 0.000000 & & \\
\hline \hline
\end{tabular}


Dependent Variable: LOG(DEN)

Method: Least Squares

Date: 03/10/11 Time: 13:18

Sample: 140

Included observations: 40

\begin{tabular}{lrlrr}
\hline \hline \multicolumn{1}{c}{ Variable } & Coefficient & \multicolumn{1}{c}{ Std. Error } & t-Statistic & Prob. \\
\hline \multicolumn{1}{c}{ C } & -2.758637 & 0.271541 & -10.15920 & 0.0000 \\
LOG(DEN1) & 1.210723 & 0.041211 & 29.37833 & 0.0000 \\
\multicolumn{1}{c}{ LOG(DEN2) } & 0.052835 & 0.036467 & 1.448836 & 0.1558 \\
\hline \hline R-squared & 0.990292 & Mean dependent var & 13.81568 \\
Adjusted R-squared & 0.989767 & S.D. dependent var & 0.241508 \\
S.E. of regression & 0.024431 & Akaike info criterion & -4.513909 \\
Sum squared resid & 0.022084 & Schwarz criterion & -4.387243 \\
Log likelihood & 93.27819 & Hannan-Quinn criter. & -4.468111 \\
F-statistic & 1887.063 & Durbin-Watson stat & 0.657592 \\
\hline \hline
\end{tabular}

Dependent Variable: LOG(EGY)

Method: Least Squares

Date: 03/10/11 Time: 13:21

Sample: 150

Included observations: 50

\begin{tabular}{lrlrr}
\hline \hline \multicolumn{1}{c}{ Variable } & Coefficient & \multicolumn{1}{c}{ Std. Error } & t-Statistic & Prob. \\
\hline \hline \multicolumn{1}{c}{ C } & 1.126595 & 0.098306 & 11.46014 & 0.0000 \\
\multicolumn{1}{c}{ LOG(EGY1) } & 0.861431 & 0.023482 & 36.68487 & 0.0000 \\
\multicolumn{1}{c}{ LOG(EGY2) } & 0.081317 & 0.020485 & 3.969599 & 0.0002 \\
\hline \hline R-squared & 0.997132 & Mean dependent var & 11.93806 \\
Adjusted R-squared & 0.997010 & S.D. dependent var & 0.761383 \\
S.E. of regression & 0.041631 & Akaike info criterion & -3.461797 \\
Sum squared resid & 0.081459 & Schwarz criterion & -3.347076 \\
Log likelihood & 89.54494 & Hannan-Quinn criter. & -3.418111 \\
F-statistic & 8171.138 & Durbin-Watson stat & 0.729432 \\
Prob(F-statistic) & 0.000000 & & \\
\hline \hline
\end{tabular}


Dependent Variable: LOG(FRA)

Method: Least Squares

Date: 03/10/11 Time: 14:13

Sample: 140

Included observations: 40

\begin{tabular}{lrlrr}
\hline \hline \multicolumn{1}{c}{ Variable } & Coefficient & \multicolumn{1}{c}{ Std. Error } & t-Statistic & Prob. \\
\hline \multicolumn{1}{c}{ C } & 0.506858 & 0.153123 & 3.310127 & 0.0021 \\
\multicolumn{1}{c}{ LOG(FRA1) } & 0.937152 & 0.026309 & 35.62084 & 0.0000 \\
\multicolumn{1}{c}{ LOG(FRA2) } & 0.072765 & 0.033736 & 2.156936 & 0.0376 \\
\hline \hline R-squared & 0.996701 & Mean dependent var & 13.92388 \\
Adjusted R-squared & 0.996523 & S.D. dependent var & 0.265122 \\
S.E. of regression & 0.015634 & Akaike info criterion & -5.406725 \\
Sum squared resid & 0.009043 & Schwarz criterion & -5.280059 \\
Log likelihood & 111.1345 & Hannan-Quinn criter. & -5.360927 \\
F-statistic & 5589.375 & Durbin-Watson stat & 0.329725 \\
Prob(F-statistic) & 0.000000 & & \\
\hline \hline
\end{tabular}

Dependent Variable: LOG(GAB)

Method: Least Squares

Date: 03/10/11 Time: 14:15

Sample: 140

Included observations: 40

\begin{tabular}{lrlrr}
\hline \hline \multicolumn{1}{c}{ Variable } & Coefficient & \multicolumn{1}{c}{ Std. Error } & t-Statistic & Prob. \\
\hline \hline \multicolumn{1}{c}{ C } & 1.821833 & 0.995295 & 1.830445 & 0.0752 \\
LOG(GAB1) & 0.506687 & 0.051947 & 9.753877 & 0.0000 \\
LOG(GAB2) & 0.441026 & 0.062193 & 7.091299 & 0.0000 \\
\hline \hline R-squared & 0.831362 & Mean dependent var & 14.90794 \\
Adjusted R-squared & 0.822246 & S.D. dependent var & 0.308691 \\
S.E. of regression & 0.130147 & Akaike info criterion & -1.168269 \\
Sum squared resid & 0.626713 & Schwarz criterion & -1.041603 \\
Log likelihood & 26.36537 & Hannan-Quinn criter. & -1.122470 \\
F-statistic & 91.20212 & Durbin-Watson stat & 1.054701 \\
\hline \hline
\end{tabular}


Dependent Variable: LOG(GAM)

Method: Least Squares

Date: 03/10/11 Time: 20:17

Sample (adjusted): 124

Included observations: 24 after adjustments

\begin{tabular}{lrlrr}
\hline \hline \multicolumn{1}{c}{ Variable } & Coefficient & \multicolumn{1}{c}{ Std. Error } & t-Statistic & Prob. \\
\hline \multicolumn{1}{c}{ C } & 2.826888 & 0.381593 & 7.408116 & 0.0000 \\
\multicolumn{1}{c}{ LOG(GAM1) } & 0.390643 & 0.065279 & 5.984236 & 0.0000 \\
\multicolumn{1}{c}{ LOG(GAM2) } & 0.355013 & 0.085632 & 4.145780 & 0.0005 \\
\hline \hline R-squared & 0.911359 & Mean dependent var & 8.326953 \\
Adjusted R-squared & 0.902917 & S.D. dependent var & 0.236247 \\
S.E. of regression & 0.073610 & Akaike info criterion & -2.263604 \\
Sum squared resid & 0.113787 & Schwarz criterion & -2.116347 \\
Log likelihood & 30.16325 & Hannan-Quinn criter. & -2.224537 \\
F-statistic & 107.9555 & Durbin-Watson stat & 1.028166 \\
Prob(F-statistic) & 0.000000 & & \\
\hline \hline
\end{tabular}

Dependent Variable: LOG(GER)

Method: Least Squares

Date: 03/10/11 Time: 20:19

Sample: 140

Included observations: 40

\begin{tabular}{lrlrr}
\hline \hline \multicolumn{1}{c}{ Variable } & Coefficient & \multicolumn{1}{c}{ Std. Error } & t-Statistic & Prob. \\
\hline \hline \multicolumn{1}{c}{ C } & -0.275290 & 0.195543 & -1.407821 & 0.1675 \\
LOG(GER1) & 0.909116 & 0.022441 & 40.51227 & 0.0000 \\
LOG(GER2) & 0.161351 & 0.032269 & 5.000234 & 0.0000 \\
\hline \hline R-squared & 0.996257 & Mean dependent var & 14.28124 \\
Adjusted R-squared & 0.996055 & S.D. dependent var & 0.251134 \\
S.E. of regression & 0.015774 & Akaike info criterion & -5.388834 \\
Sum squared resid & 0.009207 & Schwarz criterion & -5.262168 \\
Log likelihood & 110.7767 & Hannan-Quinn criter. & -5.343035 \\
F-statistic & 4923.996 & Durbin-Watson stat & 0.529321 \\
\hline \hline
\end{tabular}


Dependent Variable: LOG(GUI)

Method: Least Squares

Date: 03/10/11 Time: 20:24

Sample: 124

Included observations: 24

\begin{tabular}{lrlrr}
\hline \hline \multicolumn{1}{c}{ Variable } & Coefficient & \multicolumn{1}{c}{ Std. Error } & t-Statistic & Prob. \\
\hline \multicolumn{1}{c}{ C } & 3.732413 & 0.740571 & 5.039912 & 0.0001 \\
LOG(GUI) & 0.550955 & 0.077417 & 7.116684 & 0.0000 \\
\multicolumn{1}{c}{ LOG(GUI2) } & 0.242976 & 0.098512 & 2.466451 & 0.0223 \\
\hline \hline R-squared & 0.931704 & Mean dependent var & 15.39483 \\
Adjusted R-squared & 0.925200 & S.D. dependent var & 0.267946 \\
S.E. of regression & 0.073282 & Akaike info criterion & -2.272524 \\
Sum squared resid & 0.112777 & Schwarz criterion & -2.125267 \\
Log likelihood & 30.27029 & Hannan-Quinn criter. & -2.233457 \\
F-statistic & 143.2426 & Durbin-Watson stat & 1.146464 \\
Prob(F-statistic) & 0.000000 & & \\
\hline \hline
\end{tabular}

Dependent Variable: LOG(INDI)

Method: Least Squares

Date: 03/10/11 Time: 20:32

Sample: 150

Included observations: 50

\begin{tabular}{lrcrr}
\hline \hline \multicolumn{1}{c}{ Variable } & Coefficient & \multicolumn{1}{c}{ Std. Error } & t-Statistic & Prob. \\
\hline \multicolumn{1}{c}{ C } & -0.405477 & 0.434060 & -0.934149 & 0.3550 \\
\multicolumn{1}{c}{ LOG(INDI1) } & 0.796846 & 0.057863 & 13.77127 & 0.0000 \\
\multicolumn{1}{c}{ LOG(INDI2) } & 0.270532 & 0.033534 & 8.067491 & 0.0000 \\
\hline \hline R-squared & 0.999129 & Mean dependent var & 16.09916 \\
Adjusted R-squared & 0.999092 & S.D. dependent var & 0.728972 \\
S.E. of regression & 0.021965 & Akaike info criterion & -4.740594 \\
& & & \\
Sum squared resid & 0.022676 & Schwarz criterion & -4.625872 \\
Log likelihood & 121.5148 & Hannan-Quinn criter. & -4.696907 \\
F-statistic & 26961.30 & Durbin-Watson stat & 0.476297 \\
Prob(F-statistic) & 0.000000 & & \\
\hline \hline
\end{tabular}


Dependent Variable: LOG(INDO)

Method: Least Squares

Date: 03/10/11 Time: 20:35

Sample (adjusted): 131

Included observations: 31 after adjustments

\begin{tabular}{lrlrr}
\hline \hline \multicolumn{1}{c}{ Variable } & Coefficient & \multicolumn{1}{c}{ Std. Error } & t-Statistic & Prob. \\
\hline \multicolumn{1}{c}{ C } & 2.213085 & 0.271697 & 8.145418 & 0.0000 \\
\multicolumn{1}{c}{ LOG(INDO1) } & 0.667871 & 0.039758 & 16.79857 & 0.0000 \\
\multicolumn{1}{c}{ LOG(INDO2) } & 0.259228 & 0.040948 & 6.330685 & 0.0000 \\
\hline \hline R-squared & 0.994055 & Mean dependent var & 20.78989 \\
Adjusted R-squared & 0.993631 & S.D. dependent var & 0.471415 \\
S.E. of regression & 0.037623 & Akaike info criterion & -3.630659 \\
Sum squared resid & 0.039633 & Schwarz criterion & -3.491886 \\
Log likelihood & 59.27522 & Hannan-Quinn criter. & -3.585423 \\
F-statistic & 2341.053 & Durbin-Watson stat & 1.395847 \\
\hline \hline
\end{tabular}

Dependent Variable: LOG(IRE)

Method: Least Squares

Date: 03/10/11 Time: 20:39

Sample: 140

Included observations: 40

\begin{tabular}{lrlrr}
\hline \hline \multicolumn{1}{c}{ Variable } & Coefficient & \multicolumn{1}{c}{ Std. Error } & t-Statistic & Prob. \\
\hline \multicolumn{1}{c}{ C } & -2.658517 & 0.238011 & -11.16974 & 0.0000 \\
LOG(IRE1) & 1.272639 & 0.053563 & 23.75969 & 0.0000 \\
\multicolumn{1}{c}{ LOG(IRE2) } & 0.038198 & 0.038604 & 0.989496 & 0.3288 \\
\hline \hline R-squared & 0.994564 & Mean dependent var & 10.94307 \\
Adjusted R-squared & 0.994270 & S.D. dependent var & 0.590646 \\
S.E. of regression & 0.044709 & Akaike info criterion & -3.305223 \\
Sum squared resid & 0.073961 & Schwarz criterion & -3.178557 \\
Log likelihood & 69.10446 & Hannan-Quinn criter. & -3.259425 \\
F-statistic & 3384.713 & Durbin-Watson stat & 0.644476 \\
Prob(F-statistic) & 0.000000 & & \\
\hline \hline
\end{tabular}


Dependent Variable: LOG(JAP)

Method: Least Squares

Date: 03/10/11 Time: 20:41

Sample: 140

Included observations: 40

\begin{tabular}{lcccc}
\hline \hline \multicolumn{1}{c}{ Variable } & Coefficient & \multicolumn{1}{c}{ Std. Error } & t-Statistic & Prob. \\
\hline \multicolumn{1}{c}{ C } & 0.999647 & 0.184003 & 5.432788 & 0.0000 \\
LOG(JAP1) & 0.772261 & 0.013207 & 58.47513 & 0.0000 \\
\multicolumn{1}{c}{ LOG(JAP2) } & 0.214614 & 0.020761 & 10.33724 & 0.0000 \\
\hline \hline R-squared & 0.998685 & Mean dependent var & 19.73913 \\
Adjusted R-squared & 0.998614 & S.D. dependent var & 0.344355 \\
S.E. of regression & 0.012822 & Akaike info criterion & -5.803285 \\
Sum squared resid & 0.006083 & Schwarz criterion & -5.676619 \\
Log likelihood & 119.0657 & Hannan-Quinn criter. & -5.757486 \\
F-statistic & 14046.58 & Durbin-Watson stat & 0.521557 \\
\hline \hline
\end{tabular}

Dependent Variable: LOG(KEN)

Method: Least Squares

Date: 03/10/11 Time: 20:46

Sample: 146

Included observations: 46

\begin{tabular}{lrlrr}
\hline \hline \multicolumn{1}{c}{ Variable } & Coefficient & \multicolumn{1}{c}{ Std. Error } & t-Statistic & Prob. \\
\hline \multicolumn{1}{c}{ C } & 1.758220 & 0.137387 & 12.79759 & 0.0000 \\
LOG(KEN1) & 0.593389 & 0.034090 & 17.40650 & 0.0000 \\
LOG(KEN2) & 0.334784 & 0.035788 & 9.354588 & 0.0000 \\
\hline \hline R-squared & 0.994054 & Mean dependent var & 13.29338 \\
Adjusted R-squared & 0.993777 & S.D. dependent var & 0.580291 \\
S.E. of regression & 0.045776 & Akaike info criterion & -3.267114 \\
Sum squared resid & 0.090105 & Schwarz criterion & -3.147855 \\
Log likelihood & 78.14363 & Hannan-Quinn criter. & -3.222439 \\
F-statistic & 3594.226 & Durbin-Watson stat & 0.875776 \\
Prob(F-statistic) & 0.000000 & & \\
\hline \hline
\end{tabular}


Dependent Variable: LOG(MEX)

Method: Least Squares

Date: 03/10/11 Time: 21:03

Sample: 150

Included observations: 50

\begin{tabular}{lrlrr}
\hline \hline \multicolumn{1}{c}{ Variable } & Coefficient & \multicolumn{1}{c}{ Std. Error } & t-Statistic & Prob. \\
\hline \multicolumn{1}{c}{ C } & 0.561381 & 0.060563 & 9.269423 & 0.0000 \\
LOG(MEX1) & 0.764075 & 0.033554 & 22.77159 & 0.0000 \\
\multicolumn{1}{c}{ LOG(MEX2) } & 0.245520 & 0.032457 & 7.564567 & 0.0000 \\
\hline \hline R-squared & 0.999823 & Mean dependent var & 13.40712 \\
Adjusted R-squared & 0.999816 & S.D. dependent var & 2.237947 \\
S.E. of regression & 0.030361 & Akaike info criterion & -4.093160 \\
Sum squared resid & 0.043325 & Schwarz criterion & -3.978439 \\
Log likelihood & 105.3290 & Hannan-Quinn criter. & -4.049474 \\
F-statistic & 133089.4 & Durbin-Watson stat & 0.827800 \\
Prob(F-statistic) & 0.000000 & & \\
\hline \hline
\end{tabular}

Dependent Variable: LOG(MOR)

Method: Least Squares

Date: 03/10/11 Time: 21:06

Sample: 150

Included observations: 50

\begin{tabular}{lrlrr}
\hline \hline \multicolumn{1}{c}{ Variable } & Coefficient & \multicolumn{1}{c}{ Std. Error } & t-Statistic & Prob. \\
\hline \hline \multicolumn{1}{c}{ C } & -0.873690 & 0.255561 & -3.418710 & 0.0013 \\
LOG(MOR1) & 1.028327 & 0.040908 & 25.13744 & 0.0000 \\
\multicolumn{1}{c}{ LOG(MOR2) } & 0.087091 & 0.022784 & 3.822497 & 0.0004 \\
\hline \hline R-squared & 0.997344 & Mean dependent var & 12.34385 \\
Adjusted R-squared & 0.997231 & S.D. dependent var & 0.600041 \\
S.E. of regression & 0.031577 & Akaike info criterion & -4.014639 \\
Sum squared resid & 0.046865 & Schwarz criterion & -3.899917 \\
Log likelihood & 103.3660 & Hannan-Quinn criter. & -3.970952 \\
F-statistic & 8823.195 & Durbin-Watson stat & 0.627925 \\
Prob(F-statistic) & 0.000000 & & \\
\hline \hline
\end{tabular}


Dependent Variable: LOG(NEW)

Method: Least Squares

Date: 03/10/11 Time: 21:08

Sample (adjusted): 139

Included observations: 39 after adjustments

\begin{tabular}{lrlrr}
\hline \hline \multicolumn{1}{c}{ Variable } & Coefficient & \multicolumn{1}{c}{ Std. Error } & t-Statistic & Prob. \\
\hline \multicolumn{1}{c}{ C } & 0.266465 & 0.177095 & 1.504650 & 0.1411 \\
\multicolumn{1}{c}{ LOG(NEW1) } & 0.972649 & 0.034797 & 27.95229 & 0.0000 \\
LOG(NEW2) & 0.055355 & 0.033955 & 1.630213 & 0.1118 \\
\hline \hline R-squared & 0.991044 & Mean dependent var & 11.43913 \\
Adjusted R-squared & 0.990546 & S.D. dependent var & 0.252553 \\
S.E. of regression & 0.024556 & Akaike info criterion & -4.501951 \\
Sum squared resid & 0.021707 & Schwarz criterion & -4.373985 \\
Log likelihood & 90.78804 & Hannan-Quinn criter. & -4.456038 \\
F-statistic & 1991.817 & Durbin-Watson stat & 0.780134 \\
\hline \hline
\end{tabular}

Dependent Variable: LOG(NOR)

Method: Least Squares

Date: 03/10/11 Time: 21:12

Sample: 140

Included observations: 40

\begin{tabular}{lrlrr}
\hline \hline \multicolumn{1}{c}{ Variable } & Coefficient & \multicolumn{1}{c}{ Std. Error } & t-Statistic & Prob. \\
\hline \multicolumn{1}{c}{ C } & -1.979863 & 0.497396 & -3.980457 & 0.0003 \\
LOG(NOR1) & 1.035833 & 0.053253 & 19.45101 & 0.0000 \\
\multicolumn{1}{c}{ LOG(NOR2) } & 0.180641 & 0.072234 & 2.500769 & 0.0169 \\
\hline \hline R-squared & 0.976391 & Mean dependent var & 13.84586 \\
Adjusted R-squared & 0.975115 & S.D. dependent var & 0.370494 \\
S.E. of regression & 0.058445 & Akaike info criterion & -2.769424 \\
Sum squared resid & 0.126385 & Schwarz criterion & -2.642758 \\
Log likelihood & 58.38848 & Hannan-Quinn criter. & -2.723626 \\
F-statistic & 765.1133 & Durbin-Watson stat & 0.621118 \\
Prob(F-statistic) & 0.000000 & & \\
\hline \hline
\end{tabular}


Dependent Variable: LOG(PHI)

Method: Least Squares

Date: 03/10/11 Time: 21:26

Sample: 150

Included observations: 50

\begin{tabular}{lrlrr}
\hline \hline \multicolumn{1}{c}{ Variable } & Coefficient & Std. Error & t-Statistic & Prob. \\
\hline \multicolumn{1}{c}{ C } & 0.882711 & 0.169728 & 5.200753 & 0.0000 \\
LOG(PHI) & 0.845692 & 0.030061 & 28.13251 & 0.0000 \\
\multicolumn{1}{c}{ LOG(PHI2) } & 0.129409 & 0.030111 & 4.297723 & 0.0001 \\
\hline \hline R-squared & 0.992814 & Mean dependent var & 14.52275 \\
Adjusted R-squared & 0.992508 & S.D. dependent var & 0.530543 \\
S.E. of regression & 0.045921 & Akaike info criterion & -3.265650 \\
Sum squared resid & 0.099112 & Schwarz criterion & -3.150928 \\
Log likelihood & 84.64124 & Hannan-Quinn criter. & -3.221963 \\
F-statistic & 3246.733 & Durbin-Watson stat & 0.225382 \\
Prob(F-statistic) & 0.000000 & & \\
\hline \hline
\end{tabular}

Dependent Variable: LOG(SPA)

Method: Least Squares

Date: 03/10/11 Time: 21:47

Sample: 140

Included observations: 40

\begin{tabular}{lrlrr}
\hline \hline \multicolumn{1}{c}{ Variable } & Coefficient & \multicolumn{1}{c}{ Std. Error } & t-Statistic & Prob. \\
\hline \hline \multicolumn{1}{c}{ C } & -0.689954 & 0.128945 & -5.350746 & 0.0000 \\
LOG(SPA1) & 1.031070 & 0.026422 & 39.02244 & 0.0000 \\
\multicolumn{1}{c}{ LOG(SPA2) } & 0.068424 & 0.020132 & 3.398866 & 0.0016 \\
\hline \hline R-squared & 0.998149 & Mean dependent var & 13.04033 \\
Adjusted R-squared & 0.998049 & S.D. dependent var & 0.336325 \\
S.E. of regression & 0.014857 & Akaike info criterion & -5.508695 \\
Sum squared resid & 0.008167 & Schwarz criterion & -5.382029 \\
Log likelihood & 113.1739 & Hannan-Quinn criter. & -5.462897 \\
F-statistic & 9974.798 & Durbin-Watson stat & 0.606660 \\
Prob(F-statistic) & 0.000000 & & \\
\hline \hline
\end{tabular}


Dependent Variable: LOG(SWE)

Method: Least Squares

Date: 03/10/11 Time: 21:49

Sample: 140

Included observations: 40

\begin{tabular}{lrlrr}
\hline \hline \multicolumn{1}{c}{ Variable } & Coefficient & \multicolumn{1}{c}{ Std. Error } & t-Statistic & Prob. \\
\hline \multicolumn{1}{c}{ C } & -0.816375 & 0.150950 & -5.408249 & 0.0000 \\
LOG(SWE1) & 1.021868 & 0.019219 & 53.17017 & 0.0000 \\
LOG(SWE2) & 0.095179 & 0.021743 & 4.377512 & 0.0001 \\
\hline \hline R-squared & 0.996754 & Mean dependent var & 14.40079 \\
Adjusted R-squared & 0.996579 & S.D. dependent var & 0.245609 \\
S.E. of regression & 0.014366 & Akaike info criterion & -5.575884 \\
Sum squared resid & 0.007636 & Schwarz criterion & -5.449218 \\
Log likelihood & 114.5177 & Hannan-Quinn criter. & -5.530085 \\
F-statistic & 5681.273 & Durbin-Watson stat & 1.069933 \\
\hline \hline
\end{tabular}

Dependent Variable: LOG(THAI)

Method: Least Squares

Date: 03/10/11 Time: 21:52

Sample: 150

Included observations: 50

\begin{tabular}{lrlrr}
\hline \hline \multicolumn{1}{c}{ Variable } & Coefficient & \multicolumn{1}{c}{ Std. Error } & t-Statistic & Prob. \\
\hline \multicolumn{1}{c}{ C } & -0.794850 & 0.117751 & -6.750273 & 0.0000 \\
\multicolumn{1}{c}{ LOG(THAI1) } & 0.995892 & 0.024085 & 41.34988 & 0.0000 \\
\multicolumn{1}{c}{ LOG(THAI2) } & 0.101260 & 0.017808 & 5.686240 & 0.0000 \\
\hline \hline R-squared & 0.999163 & Mean dependent var & 14.46298 \\
Adjusted R-squared & 0.999127 & S.D. dependent var & 0.946413 \\
S.E. of regression & 0.027956 & Akaike info criterion & -4.258236 \\
Sum squared resid & 0.036733 & Schwarz criterion & -4.143515 \\
Log likelihood & 109.4559 & Hannan-Quinn criter. & -4.214550 \\
F-statistic & 28054.98 & Durbin-Watson stat & 0.873848 \\
Prob(F-statistic) & 0.000000 & & \\
\hline \hline
\end{tabular}


Dependent Variable: LOG(TUNI)

Method: Least Squares

Date: 03/10/11 Time: 21:54

Sample (adjusted): 149

Included observations: 49 after adjustments

\begin{tabular}{lrlrr}
\hline \hline \multicolumn{1}{c}{ Variable } & Coefficient & \multicolumn{1}{c}{ Std. Error } & t-Statistic & Prob. \\
\hline \multicolumn{1}{c}{ C } & 1.207130 & 0.078459 & 15.38542 & 0.0000 \\
LOG(TUNI) & 0.814497 & 0.039878 & 20.42452 & 0.0000 \\
\multicolumn{1}{c}{ LOG(TUNI2) } & 0.120139 & 0.040136 & 2.993305 & 0.0044 \\
\hline \hline R-squared & 0.996399 & Mean dependent var & 9.480187 \\
Adjusted R-squared & 0.996243 & S.D. dependent var & 0.698607 \\
S.E. of regression & 0.042823 & Akaike info criterion & -3.404235 \\
Sum squared resid & 0.084353 & Schwarz criterion & -3.288409 \\
Log likelihood & 86.40375 & Hannan-Quinn criter. & -3.360290 \\
F-statistic & 6364.519 & Durbin-Watson stat & 0.902709 \\
\hline \hline
\end{tabular}

Dependent Variable: LOG(TUR)

Method: Least Squares

Date: 03/10/11 Time: 21:58

Sample: 142

Included observations: 42

\begin{tabular}{lrlrr}
\hline \hline \multicolumn{1}{c}{ Variable } & Coefficient & \multicolumn{1}{c}{ Std. Error } & t-Statistic & Prob. \\
\hline \multicolumn{1}{c}{ C } & 0.728660 & 0.063252 & 11.51993 & 0.0000 \\
LOG(TUR1) & 0.939396 & 0.045288 & 20.74270 & 0.0000 \\
\multicolumn{1}{c}{ LOG(TUR2) } & 0.032472 & 0.044522 & 0.729342 & 0.4702 \\
\hline \hline R-squared & 0.999847 & Mean dependent var & 8.693329 \\
Adjusted R-squared & 0.999840 & S.D. dependent var & 3.555831 \\
S.E. of regression & 0.045038 & Akaike info criterion & -3.293871 \\
Sum squared resid & 0.079108 & Schwarz criterion & -3.169752 \\
Log likelihood & 72.17129 & Hannan-Quinn criter. & -3.248376 \\
F-statistic & 127764.8 & Durbin-Watson stat & 1.511434 \\
Prob(F-statistic) & 0.000000 & & \\
\hline \hline
\end{tabular}


Dependent Variable: LOG(UK)

Method: Least Squares

Date: 03/10/11 Time: 22:00

Sample (adjusted): 140

Included observations: 40 after adjustments

\begin{tabular}{lrlrr}
\hline \hline \multicolumn{1}{c}{ Variable } & Coefficient & \multicolumn{1}{c}{ Std. Error } & t-Statistic & Prob. \\
\hline \multicolumn{1}{c}{ C } & 1.757902 & 0.160501 & 10.95263 & 0.0000 \\
LOG(UK1) & 0.855376 & 0.029990 & 28.52248 & 0.0000 \\
\multicolumn{1}{c}{ LOG(UK2) } & 0.051060 & 0.040470 & 1.261673 & 0.2150 \\
\hline \hline R-squared & 0.996018 & Mean dependent var & 13.51726 \\
Adjusted R-squared & 0.995803 & S.D. dependent var & 0.279269 \\
S.E. of regression & 0.018093 & Akaike info criterion & -5.114556 \\
Sum squared resid & 0.012112 & Schwarz criterion & -4.987890 \\
Log likelihood & 105.2911 & Hannan-Quinn criter. & -5.068758 \\
F-statistic & 4627.329 & Durbin-Watson stat & 0.295150 \\
\hline \hline
\end{tabular}

Dependent Variable: LOG(US)

Method: Least Squares

Date: 03/10/11 Time: 22:02

Sample: 140

Included observations: 40

\begin{tabular}{lrlrr}
\hline \hline \multicolumn{1}{c}{ Variable } & Coefficient & \multicolumn{1}{c}{ Std. Error } & t-Statistic & Prob. \\
\hline \multicolumn{1}{c}{ C } & 1.892269 & 0.045430 & 41.65270 & 0.0000 \\
LOG(US1) & 0.816620 & 0.012865 & 63.47526 & 0.0000 \\
\multicolumn{1}{c}{ LOG(US2) } & 0.094610 & 0.014738 & 6.419224 & 0.0000 \\
\hline \hline R-squared & 0.999639 & Mean dependent var & 15.74328 \\
Adjusted R-squared & 0.999620 & S.D. dependent var & 0.356872 \\
S.E. of regression & 0.006957 & Akaike info criterion & -7.026138 \\
Sum squared resid & 0.001791 & Schwarz criterion & -6.899472 \\
Log likelihood & 143.5228 & Hannan-Quinn criter. & -6.980339 \\
F-statistic & 51295.11 & Durbin-Watson stat & 0.994882 \\
Prob(F-statistic) & 0.000000 & & \\
\hline \hline
\end{tabular}


Dependent Variable: LOG(ZAM)

Method: Least Squares

Date: 03/10/11 Time: 22:04

Sample: 140

Included observations: 40

\begin{tabular}{lcccr}
\hline \hline \multicolumn{1}{c}{ Variable } & Coefficient & \multicolumn{1}{c}{ Std. Error } & t-Statistic & Prob. \\
\hline \multicolumn{1}{c}{ C } & 1.566146 & 0.134541 & 11.64068 & 0.0000 \\
LOG(ZAM1) & 0.736345 & 0.032772 & 22.46856 & 0.0000 \\
\multicolumn{1}{c}{ LOG(ZAM2) } & 0.206536 & 0.038966 & 5.300430 & 0.0000 \\
\hline \hline R-squared & 0.996596 & Mean dependent var & 14.53387 \\
Adjusted R-squared & 0.996412 & S.D. dependent var & 1.863151 \\
S.E. of regression & 0.111599 & Akaike info criterion & -1.475780 \\
Sum squared resid & 0.460806 & Schwarz criterion & -1.349114 \\
Log likelihood & 32.51559 & Hannan-Quinn criter. & -1.429981 \\
F-statistic & 5416.681 & Durbin-Watson stat & 1.115131 \\
\hline \hline
\end{tabular}




\section{Appendix B: Dating the Business Cycles}

\begin{tabular}{|c|c|c|c|c|c|c|c|c|c|c|c|c|c|c|c|c|c|}
\hline \multicolumn{6}{|c|}{ GDP } & \multicolumn{6}{|c|}{ Consumption } & \multicolumn{6}{|c|}{ Investment } \\
\hline \multicolumn{3}{|c|}{ CTS } & \multicolumn{3}{|c|}{ ETS } & \multicolumn{3}{|c|}{ CTS } & \multicolumn{3}{|c|}{ ETS } & \multicolumn{3}{|c|}{ CTS } & \multicolumn{3}{|c|}{ ETS } \\
\hline DUR & AMP & CUM & DUR & AMP & CUM & DUR & AMP & CUM & DUR & AMP & CUM & DUR & AMP & CUM & DUR & AMP & CUM \\
\hline 2.5 & 11.39 & 13.78 & 3 & 16.62 & 16.3 & 1.5 & 17.2 & 11.4 & 1 & 0.19 & 0.09 & 2 & 71.22 & 116.78 & 3 & 27.18 & 40.06 \\
\hline 1 & 1.8 & 0.9 & 7 & 26.14 & 17.6 & 1 & 1.81 & 0.91 & 2 & 13.8 & 13.03 & 1.5 & 9.53 & 7.96 & 4.2 & 23.68 & 64.24 \\
\hline 3 & 16.09 & 18.05 & 3 & 19.68 & 15.36 & 1 & 11.29 & 5.65 & 2.5 & 11.4 & 17.95 & 2.33 & 18.62 & 29.57 & 1.5 & 9.91 & 28.49 \\
\hline 1 & 2.94 & 1.47 & 8 & 27.85 & 128 & 1 & 0.62 & 0.31 & 5 & 18.85 & 77.79 & 2 & 10.86 & 19.39 & 3.67 & 21.33 & 44.73 \\
\hline 1 & 7.32 & 3.66 & 9 & 21.62 & 21.87 & 1.2 & 6.46 & 6.23 & 5.5 & 34.09 & 156.76 & 1.14 & 14.28 & 13.29 & 3.33 & 39.77 & 104.37 \\
\hline 1 & 1.21 & 0.99 & 4.4 & 15.57 & 27.11 & 1.25 & 2.13 & 3.79 & 6.25 & 16.64 & 43.88 & 2.14 & 10.83 & 10 & 2.71 & 18.41 & 34.58 \\
\hline 1 & 2.02 & 1.01 & 17 & 28.78 & 116.51 & 1 & 1.24 & 0.62 & 10.5 & 32.72 & 140.87 & 1.83 & 5.96 & 5.44 & 3.4 & 13.68 & 34.15 \\
\hline 1.25 & 0.87 & 0.57 & 8 & 21.21 & 86.77 & 1 & 0.63 & 0.32 & 7.33 & 15.82 & 57.13 & 2.5 & 9.21 & 17.27 & 3.6 & 15.5 & 36.68 \\
\hline 1.17 & 8.2 & 4.48 & 2.6 & 33.12 & 17.48 & 1 & 6.63 & 3.31 & 2.8 & 16.07 & 26.5 & 2.17 & 21.8 & 27.08 & 3.5 & 27.69 & 70.18 \\
\hline 1 & 0.65 & 0.32 & 21 & 29.97 & 132.65 & 1.25 & 2.64 & 3.59 & 4.67 & 20.29 & 58.21 & 2 & 11.9 & 33.88 & 4.6 & 48.48 & 77.64 \\
\hline 1.25 & 1.3 & 1.18 & 7.25 & 16.84 & 177.64 & 1 & 0.88 & 0.44 & 23 & 30.52 & 114.74 & 1.75 & 8.63 & 13.44 & 4 & 19.13 & 62.21 \\
\hline 1 & 4.21 & 2.11 & 12 & 14.7 & 403.22 & 1.5 & 9.73 & 5.52 & 10 & 12.01 & 166.11 & 2.25 & 25.94 & 36.86 & 6 & 72.41 & 85.88 \\
\hline 1.5 & 6.6 & 3.3 & 4.75 & 14.41 & 56.65 & 1 & 6.34 & 3.17 & 4.5 & 25.17 & 65.05 & 1.4 & 11.09 & 9.07 & 2.75 & 25.32 & 52.66 \\
\hline 1.04 & 3.46 & 6.56 & 5.5 & 21.63 & 72.02 & 1.25 & 3.56 & 8.44 & 5.75 & 18.08 & 72.06 & 2.4 & 18.57 & 28.68 & 3.6 & 27.3 & 69.6 \\
\hline 1 & 0.4 & 0.2 & 4 & 20.96 & 58.5 & 1.75 & 4.27 & 3.48 & 7.33 & 26.44 & 35.99 & 1.2 & 11 & 27.42 & 3.8 & 23.17 & 46.69 \\
\hline 1.33 & 13.89 & 4.48 & 2.75 & 12.2 & 43.24 & 1 & 11.04 & 3.52 & 2.33 & 18.01 & 28.71 & 2.14 & 20.6 & 11.45 & 2 & 22.63 & 27.59 \\
\hline 1 & 1.78 & 0.89 & 5 & 15.64 & 63.49 & 1 & 2.06 & 1.03 & 4 & 14.84 & 48.05 & 1.8 & 9.44 & 9.23 & 4.8 & 28.83 & 26.47 \\
\hline 1.1 & 2.14 & 1.82 & 8.67 & 15.4 & 145.26 & 1 & 0.73 & 0.37 & 4.6 & 13.19 & 66.53 & 1.17 & 10.21 & 13.72 & 3.4 & 18.07 & 42.39 \\
\hline 1 & 9.05 & 4.52 & 2.5 & 15.2 & 29.84 & 1.33 & 8.68 & 4.37 & 3.33 & 23.96 & 57.1 & 1.33 & 29.03 & 18.6 & 3.33 & 38.06 & 92.41 \\
\hline 1.33 & 1.84 & 1.14 & 7 & 12.66 & 80.99 & 1.33 & 1.56 & 1.23 & 6.5 & 10.18 & 83.74 & 1.8 & 9.95 & 15.38 & 4.8 & 22.02 & 76.88 \\
\hline 1 & 0.88 & 0.44 & 7.5 & 26.07 & 152.64 & 0 & 0 & 0 & 0 & 0 & 0 & 1.6 & 7.78 & 5.54 & 5 & 31.6 & 89.28 \\
\hline 1 & 2.15 & 1.08 & 1 & 2.74 & 1.37 & 1 & 1.99 & 0.99 & 4.33 & 20.25 & 63.74 & 1 & 8.99 & 4.5 & 4.67 & 53.39 & 42.75 \\
\hline 1 & 2.42 & 1.21 & 1 & 3.4 & 201.7 & 1.33 & 1.31 & 1.14 & 1 & 3.4 & 1.7 & 1.8 & 19.03 & 23.56 & 2.5 & 33.05 & 52.42 \\
\hline 1.71 & 5.49 & 11.89 & 3.33 & 14.73 & 42.34 & 1.5 & 10.36 & 12.78 & 3.43 & 19.04 & 41.03 & 1.22 & 23.84 & 18.56 & 1.5 & 33.33 & 63.78 \\
\hline 1 & 1.8 & 0.9 & 4 & 28.3 & 11.84 & 2 & 8.05 & 4.03 & 1 & 7.73 & 3.86 & 1.5 & 6.22 & 3.11 & 5.5 & 61.23 & 94.83 \\
\hline 1.25 & 3 & 4.3 & 4.4 & 27.57 & 87.11 & 1.55 & 14.14 & 13.4 & 1.3 & 15.27 & 12.99 & 2.17 & 36.3 & 94.34 & 2.17 & 51.74 & 77.62 \\
\hline 1.83 & 13.13 & 18.06 & 3 & 15.45 & 32.43 & 1.6 & 17.24 & 14.22 & 1.78 & 25.38 & 25.04 & 1.45 & 34.88 & 44.26 & 1.7 & 39.72 & 47.06 \\
\hline 1 & 1.4 & 0.7 & 7.5 & 28.99 & 100 & 1.5 & 5.68 & 5.81 & 4 & 38.99 & 79.91 & 1.2 & 11.83 & 6.36 & 2.5 & 26.37 & 45.87 \\
\hline 1.5 & 1.22 & 1.03 & 7 & 11.32 & 28.08 & 1.5 & 10.13 & 7.38 & 12 & 71.63 & 29.86 & 1.8 & 12.56 & 14.05 & 2 & 18.51 & 25.14 \\
\hline 1.25 & 2.84 & 2.09 & 4.67 & 29.77 & 11.58 & 1 & 3.75 & 1.88 & 5 & 23.65 & 88.71 & 2 & 6.04 & 3.02 & 8 & 67.08 & 88.64 \\
\hline 1 & 15.86 & 8.84 & 0 & 0 & 0 & 2.75 & 10.12 & 13.06 & 1 & 10.82 & 5.41 & 1.71 & 17.74 & 21.1 & 2 & 26.51 & 38.21 \\
\hline 1 & 4.11 & 2.06 & 5.33 & 21.71 & 98.24 & 1.14 & 5.72 & 1.93 & 3.67 & $\begin{array}{r}27.29 \\
\end{array}$ & 69.72 & 1.63 & 13.46 & 15.43 & 2.57 & 25.61 & 31.38 \\
\hline 1.17 & 3.29 & 2.28 & 2 & 14.44 & 17.62 & 1.17 & 3.77 & 2.49 & 2.4 & 14.55 & 21.35 & 1.33 & 9.58 & 7.03 & 2 & 14.02 & 18.08 \\
\hline 1.25 & 4.34 & 4.27 & 6.67 & 30.3 & 104.04 & 2 & 2.57 & 2.59 & 0 & 0 & 0 & 1.33 & 22.53 & 19.42 & 2.8 & 24.27 & 35.08 \\
\hline 1 & 1.53 & 0.77 & 12 & 26.82 & 46.28 & 1 & 2.99 & 1.5 & 8 & 51.41 & 41.04 & 2.25 & 12.86 & 22.26 & 4 & 34.16 & 58.13 \\
\hline 1.25 & 9.51 & 7.2 & 6.33 & 23.65 & 26.29 & 1.67 & 10.46 & 10.32 & 4.2 & 49.25 & 90.06 & 1.5 & 13.07 & 11.97 & 4.33 & 105.44 & 52.58 \\
\hline
\end{tabular}




\section{Appendix C: Estimation of Random Walk Models}

\begin{tabular}{|c|c|c|c|c|c|c|c|c|}
\hline \multicolumn{3}{|c|}{ GDP } & \multicolumn{3}{|c|}{ Consumption } & \multicolumn{3}{|c|}{ Investment } \\
\hline$\mu$ & $\sigma$ & $\mu / \sigma$ & $\mu$ & $\bar{\sigma}$ & $\mu / \sigma$ & $\mu$ & $\sigma$ & $\mu / \sigma$ \\
\hline 9686.81 & 17422.81 & 0.555984368 & 3881.438 & 15348.48 & 0.252887452 & 2310.375 & 8653.657 & 0.266982502 \\
\hline 16076.05 & 10337.52 & 1.555116701 & 8354.564 & 4911.57 & 1.700996626 & 4173 & 7907.367 & 0.527735718 \\
\hline 74461.24 & 306098.2 & 0.24325932 & 45782 & 184050.1 & 0.248747488 & 12457.62 & 60337.75 & 0.206464775 \\
\hline 21853.67 & 17836.5 & 1.225221876 & 13168.54 & 8139.146 & 1.6179265 & 4726.846 & 10194.32 & 0.463674478 \\
\hline 142854 & 1570751 & 0.090946305 & 854625.2 & 1195670 & 0.714766783 & 306202.4 & 802042.1 & 0.381778463 \\
\hline 18090.38 & 23883.11 & 0.757454955 & 7490.256 & 13412.24 & 0.558464209 & 2112.59 & 16869.51 & 0.12523126 \\
\hline 24298 & 20369.85 & 1.192841381 & 14368.55 & 9609.664 & 1.495218771 & 4432.641 & 11509.07 & 0.385143283 \\
\hline 30179.03 & 33593.54 & 0.898358137 & 18229 & 15115.7 & 1.205964659 & 2817.821 & 18365.65 & 0.153428874 \\
\hline 3221.974 & 6879.57 & 0.468339446 & 2434.795 & 4016.063 & 0.606264145 & 448.1026 & 3100.916 & 0.144506526 \\
\hline 2945.41 & 3904.265 & 0.75440832 & 1325.282 & 1890.571 & 0.700995625 & 407.2051 & 2798.453 & 0.145510788 \\
\hline 8759279 & 9934965 & 0.881661787 & 5749732 & 3622342 & 1.587296837 & 1093670 & 6420461 & 0.170341351 \\
\hline 12207.18 & 11293.49 & 1.080904131 & 5980.256 & 7083.001 & 0.844311048 & 2480.744 & 12148.7 & 0.204198309 \\
\hline 156825.3 & 305716.9 & 0.512975567 & 105716.3 & 193417.2 & 0.546571349 & 34226.79 & 75336.86 & 0.454316652 \\
\hline 2134.5 & 2616.03 & 0.81593101 & 1152.658 & 1797.386 & 0.641296861 & 440.4737 & 1790.576 & 0.245995534 \\
\hline 31652.72 & 19469.1 & 1.625792666 & 12082.69 & 21803.4 & 0.554165405 & 6162.564 & 21933.77 & 0.28096237 \\
\hline 20825.26 & 47869.07 & 0.435046263 & 12828.69 & 30247.32 & 0.424126501 & 4493.256 & 19209.94 & 0.233902657 \\
\hline 13684.51 & 13298.59 & 1.029019618 & 7383.692 & 8382.123 & 0.880885666 & 3148.051 & 11162.73 & 0.282014436 \\
\hline 36300.51 & 47548.7 & 0.763438538 & 16922.7 & 16465.98 & 1.027737189 & 4802.744 & 27148.45 & 0.176906748 \\
\hline 5726.41 & 13211.51 & 0.433440992 & 4096.59 & 9234.662 & 0.443610172 & 965.8462 & 4712.852 & 0.204938793 \\
\hline 16511.54 & 17396.92 & 0.949107083 & 11325.82 & 10530.6 & 1.075515165 & 1843.538 & 9687.081 & 0.190308928 \\
\hline 194634.2 & 158434 & 1.228487572 & 145232.9 & 97072.85 & 1.496122757 & 26568.56 & 95517.85 & 0.278152827 \\
\hline 46448.74 & 34123.39 & 1.361199459 & 33359.35 & 39877.77 & 0.836540007 & 12635.3 & 38114.73 & 0.331507005 \\
\hline 2503 & 5504 & 0.454760174 & 1219.282 & 3616.115 & 0.337180095 & 412.4828 & 1299.998 & 0.31729495 \\
\hline 8902.949 & 22997.91 & 0.387119917 & 7702.629 & 34561.45 & 0.222867646 & 2032.538 & 15287.68 & 0.132952678 \\
\hline 602246.1 & 650735.7 & 0.925484955 & 209036.6 & 193632.5 & 1.079553277 & 279309 & 408289.1 & 0.684096147 \\
\hline 68795.71 & 104125.3 & 0.660701194 & 26133.74 & 131477.1 & 0.19877028 & 14273.2 & 131630.4 & 0.108433918 \\
\hline 78750.13 & 288120.4 & 0.273323687 & 33706.38 & 192663.7 & 0.174949303 & 21772.15 & 306647.5 & 0.071000579 \\
\hline 197.82 & 157.75 & 1.254009509 & 187.61 & 338.22 & 0.554698125 & 37.17 & 122.44 & 0.303577262 \\
\hline 173139.8 & 77438.25 & 2.235843398 & 307983.1 & 738056.7 & 0.417289214 & 46239.09 & 146545.9 & 0.31552633 \\
\hline 269.18 & 255.12 & 1.05511132 & 464694.8 & 481746.5 & 0.964604413 & 311155.3 & 416166.8 & 0.747669684 \\
\hline 879482.6 & 875946.2 & 1.004037234 & 200.45 & 286.59 & 0.699431243 & 29.64 & 259.99 & 0.114004385 \\
\hline 29295.33 & 26345.68 & 1.111959532 & 24666.51 & 31879.81 & 0.773734536 & 5908.744 & 15719.45 & 0.375887452 \\
\hline 12522.41 & 14518.07 & 0.86253958 & 6605.231 & 9389.581 & 0.703463871 & 4351.359 & 7340.333 & 0.592801308 \\
\hline 97609.97 & 93855.01 & 1.040008093 & 74366.28 & 54661.88 & 1.360477905 & 13384.31 & 67449.06 & 0.198435827 \\
\hline 875.4872 & 568.5298 & 1.539914355 & 547.0769 & 366.2258 & 1.493824029 & 234.4103 & 362.1392 & 0.647293361 \\
\hline 410353.5 & 757125.1 & 0.541989032 & 243770.4 & 674087.6 & 0.36163015 & 84574.18 & 188276.8 & 0.449201282 \\
\hline
\end{tabular}




\section{Appendix D: Endogeneity Test Result}

Dependent Variable: Gini

Method: Least Squares

Date: 03/30/13 Time: 09:25

Sample: 136

Included observations: 36

\begin{tabular}{lrrrr}
\hline \hline \multicolumn{1}{c}{ Variable } & Coefficient & \multicolumn{1}{c}{ Std. Error } & t-Statistic & Prob. \\
\hline \multicolumn{1}{c}{ TL } & -0.461872 & 0.071664 & -6.444955 & 0.0000 \\
\multicolumn{1}{c}{ UPOP } & 0.189597 & 0.066646 & 2.844860 & 0.0076 \\
\multicolumn{1}{c}{38.39357} & 3.225123 & 11.90453 & 0.0000 \\
\hline \hline R-squared & 0.593981 & Mean dependent var & 40.22528 \\
Adjusted R-squared & 0.569373 & S.D. dependent var & 9.083354 \\
S.E. of regression & 5.960692 & Akaike info criterion & 6.487905 \\
Sum squared resid & 1172.485 & Schwarz criterion & 6.619865 \\
Log likelihood & -113.7823 & Hannan-Quinn criter. & 6.533963 \\
F-statistic & 24.13846 & Durbin-Watson stat & 2.473871 \\
Prob(F-statistic) & 0.000000 & & \\
\hline \hline
\end{tabular}

Dependent Variable: DUR

Method: Least Squares

Date: 03/30/13 Time: 10:11

Sample: 136

Included observations: 36

\begin{tabular}{lrlrl}
\hline \hline \multicolumn{1}{c}{ Variable } & Coefficient & Std. Error & t-Statistic & Prob. \\
\hline \multicolumn{1}{c}{ GINI } & 0.030807 & 0.001662 & 18.53846 & 0.0000 \\
\multicolumn{1}{c}{ RES } & -0.021158 & 0.012000 & -1.763130 & 0.0869 \\
\hline \hline R-squared & 0.143991 & Mean dependent var & 1.248056 \\
Adjusted R-squared & 0.118814 & S.D. dependent var & 0.433509 \\
S.E. of regression & 0.409452 & Akaike info criterion & 1.131662 \\
Sum squared resid & 5.532485 & Schwarz criterion & 1.263622 \\
Log likelihood & -17.36991 & Hannan-Quinn criter. & 1.177719 \\
F-statistic & 3.116826 & Durbin-Watson stat & 2.053201 \\
Prob(F-statistic) & 0.057559 & & \\
\hline \hline
\end{tabular}


Dependent Variable: AMP

Method: Least Squares

Date: 03/30/13 Time: 10:12

Sample: 136

Included observations: 36

\begin{tabular}{lrlrr}
\hline \hline \multicolumn{1}{c}{ Variable } & Coefficient & \multicolumn{1}{c}{ Std. Error } & t-Statistic & Prob. \\
\hline \multicolumn{1}{c}{ GINI } & 0.356157 & 0.091163 & 3.906834 & 0.0004 \\
RES & -0.217545 & 0.143068 & -1.520565 & 0.1379 \\
\multicolumn{1}{c}{ C } & -9.545134 & 3.720640 & -2.565455 & 0.0150 \\
\hline \hline R-squared & 0.337930 & Mean dependent var & 4.781389 \\
Adjusted R-squared & 0.297805 & S.D. dependent var & 4.505616 \\
S.E. of regression & 3.775576 & Akaike info criterion & 5.574638 \\
Sum squared resid & 470.4141 & Schwarz criterion & 5.706598 \\
Log likelihood & -97.34349 & Hannan-Quinn criter. & 5.620696 \\
F-statistic & 8.421839 & Durbin-Watson stat & 2.200317 \\
Prob(F-statistic) & 0.001109 & & \\
\hline \hline
\end{tabular}

Dependent Variable: CUM

Method: Least Squares

Date: 03/30/13 Time: 10:16

Sample: 136

Included observations: 36

\begin{tabular}{lrlrl}
\hline \hline \multicolumn{1}{c}{ Variable } & Coefficient & \multicolumn{1}{c}{ Std. Error } & t-Statistic & Prob. \\
\hline \hline \multicolumn{1}{c}{ GINI } & 0.322157 & 0.104175 & 3.092474 & 0.0040 \\
RES & -0.291412 & 0.163489 & -1.782454 & 0.0839 \\
\multicolumn{1}{c}{ C } & -9.026917 & 4.251701 & -2.123131 & 0.0413 \\
\hline \hline R-squared & 0.225769 & Mean dependent var & 3.931944 \\
Adjusted R-squared & 0.178846 & S.D. dependent var & 4.761194 \\
S.E. of regression & 4.314477 & Akaike info criterion & 5.841485 \\
Sum squared resid & 614.2856 & Schwarz criterion & 5.973445 \\
Log likelihood & -102.1467 & Hannan-Quinn criter. & 5.887542 \\
F-statistic & 4.811467 & Durbin-Watson stat & 2.373391 \\
Prob(F-statistic) & 0.014668 & & \\
\hline \hline
\end{tabular}




\section{Appendix E: Omitted Variable Test}

Omitted Variables Test

Equation: UNTITLED

Specification: DUR GINI C

Omitted Variables: RIR IR

\begin{tabular}{lccc}
\hline \hline & Value & df & Probability \\
\cline { 2 - 4 } F-statistic & 12.69816 & $(2,32)$ & 0.0001 \\
Likelihood ratio & 21.03279 & 2 & 0.0000 \\
\hline \hline
\end{tabular}

F-test summary:

Test SSR

Restricted SSR

Unrestricted SSR

\begin{tabular}{ccc} 
Sum of Sq. & df & Mean Squares \\
\hline 2.505889 & 2 & 1.252944 \\
5.663372 & 34 & 0.166570 \\
3.157483 & 32 & 0.098671 \\
3.157483 & 32 & 0.098671
\end{tabular}

LR test summary:

Restricted $\log \mathrm{L}$

\begin{tabular}{cc} 
Value & df \\
\hline-17.79080 & 34 \\
-7.274401 & 32
\end{tabular}

Unrestricted Test Equation:

Dependent Variable: DUR

Method: Least Squares

Date: 03/31/13 Time: 17:30

Sample: 136

Included observations: 36

\begin{tabular}{lrlll}
\hline \hline \multicolumn{1}{c}{ Variable } & Coefficient & Std. Error & t-Statistic & Prob. \\
\hline \hline \multicolumn{1}{c}{ GINI } & 0.001434 & 0.006894 & 0.207931 & 0.8366 \\
C & 0.964976 & 0.270420 & 3.568428 & 0.0012 \\
RIR & 0.025594 & 0.009080 & 2.818791 & 0.0082 \\
IR & 0.001440 & 0.000829 & 1.737072 & 0.0920 \\
\hline \hline R-squared & 0.519962 & Mean dependent var & 1.248056 \\
Adjusted R-squared & 0.474958 & S.D. dependent var & 0.433509 \\
S.E. of regression & 0.314120 & Akaike info criterion & 0.626356 \\
Sum squared resid & 3.157483 & Schwarz criterion & 0.802302 \\
Log likelihood & -7.274401 & Hannan-Quinn criter. & 0.687766 \\
F-statistic & 11.55378 & Durbin-Watson stat & 2.170703 \\
Prob(F-statistic) & 0.000027 & & \\
\hline \hline
\end{tabular}


Omitted Variables Test

Equation: UNTITLED

Specification: AMP GINI C

Omitted Variables: RIR IR

\begin{tabular}{lccc}
\hline \hline & Value & df & Probability \\
\cline { 2 - 4 } F-statistic & 1.417880 & $(2,32)$ & 0.2570 \\
Likelihood ratio & 3.056707 & 2 & 0.2169 \\
\hline \hline
\end{tabular}

F-test summary:

Test SSR

Restricted SSR

Unrestricted SSR

Unrestricted SSR

\begin{tabular}{ccc} 
Sum of Sq. & df & Mean Squares \\
\hline 40.97644 & 2 & 20.48822 \\
503.3732 & 34 & 14.80510 \\
462.3968 & 32 & 14.44990 \\
462.3968 & 32 & 14.44990
\end{tabular}

LR test summary:

Restricted LogL

\begin{tabular}{cc} 
Value & df \\
\hline-98.56242 & 34 \\
-97.03407 & 32
\end{tabular}

Unrestricted LogL

Unrestricted Test Equation:

Dependent Variable: AMP

Method: Least Squares

Date: 03/31/13 Time: 17:32

Sample: 136

Included observations: 36

\begin{tabular}{lrlrl}
\hline \hline \multicolumn{1}{c}{ Variable } & Coefficient & \multicolumn{1}{c}{ Std. Error } & t-Statistic & Prob. \\
\hline \multicolumn{1}{c}{ GINI } & 0.220803 & 0.083433 & 2.646470 & 0.0125 \\
C & -5.101145 & 3.272476 & -1.558803 & 0.1289 \\
RIR & 0.156032 & 0.109880 & 1.420020 & 0.1653 \\
IR & -0.000976 & 0.010033 & -0.097295 & 0.9231 \\
\hline \hline R-squared & 0.349214 & Mean dependent var & 4.781389 \\
Adjusted R-squared & 0.288203 & S.D. dependent var & 4.505616 \\
S.E. of regression & 3.801302 & Akaike info criterion & 5.613004 \\
Sum squared resid & 462.3968 & Schwarz criterion & 5.788950 \\
Log likelihood & -97.03407 & Hannan-Quinn criter. & 5.674414 \\
F-statistic & 5.723763 & Durbin-Watson stat & 2.359582 \\
Prob(F-statistic) & 0.002973 & & \\
\hline \hline
\end{tabular}


Omitted Variables Test

Equation: UNTITLED

Specification: CUM GINI C

Omitted Variables: RIR IR

\begin{tabular}{lccc}
\hline \hline & Value & df & Probability \\
\cline { 2 - 4 } F-statistic & 3.915704 & $(2,32)$ & 0.0301 \\
Likelihood ratio & 7.881114 & 2 & 0.0194 \\
\hline \hline
\end{tabular}

F-test summary:

Test SSR

Restricted SSR

Unrestricted SSR

Unrestricted SSR

\begin{tabular}{ccc} 
Sum of Sq. & df & Mean Squares \\
\hline 132.4051 & 2 & 66.20257 \\
673.4272 & 34 & 19.80668 \\
541.0220 & 32 & 16.90694 \\
541.0220 & 32 & 16.90694
\end{tabular}

LR test summary:

Restricted LogL

\begin{tabular}{cc} 
Value & df \\
\hline-103.8013 & 34 \\
-99.86073 & 32
\end{tabular}

Unrestricted LogL

Unrestricted Test Equation:

Dependent Variable: CUM

Method: Least Squares

Date: 03/31/13 Time: 17:33

Sample: 136

Included observations: 36

\begin{tabular}{lrlrl}
\hline \hline \multicolumn{1}{c}{ Variable } & Coefficient & \multicolumn{1}{c}{ Std. Error } & t-Statistic & Prob. \\
\hline \multicolumn{1}{c}{ GINI } & 0.095401 & 0.090248 & 1.057093 & 0.2984 \\
C & -1.636278 & 3.539782 & -0.462254 & 0.6470 \\
RIR & 0.224954 & 0.118855 & 1.892676 & 0.0675 \\
IR & 0.006115 & 0.010853 & 0.563481 & 0.5770 \\
\hline \hline R-squared & 0.318109 & Mean dependent var & 3.931944 \\
Adjusted R-squared & 0.254181 & S.D. dependent var & 4.761194 \\
S.E. of regression & 4.111805 & Akaike info criterion & 5.770040 \\
Sum squared resid & 541.0220 & Schwarz criterion & 5.945987 \\
Log likelihood & -99.86073 & Hannan-Quinn criter. & 5.831450 \\
F-statistic & 4.976097 & Durbin-Watson stat & 2.456398 \\
Prob(F-statistic) & 0.006032 & & \\
\hline \hline
\end{tabular}


Appendix F: Estimation of Amplitude of Recessions

Dependent Variable: AMP

Method: Least Squares

Date: 04/01/13 Time: 15:10

Sample: 136

Included observations: 36

\begin{tabular}{lrlrr}
\hline \hline \multicolumn{1}{c}{ Variable } & Coefficient & \multicolumn{1}{c}{ Std. Error } & t-Statistic & Prob. \\
\hline \multicolumn{1}{c}{ GINI } & 0.267830 & 0.071602 & 3.740535 & 0.0007 \\
\multicolumn{1}{c}{ C } & -5.992143 & 2.950741 & -2.030725 & 0.0502 \\
\hline \hline R-squared & 0.291543 & Mean dependent var & 4.781389 \\
Adjusted R-squared & 0.270706 & S.D. dependent var & 4.505616 \\
S.E. of regression & 3.847739 & Akaike info criterion & 5.586801 \\
Sum squared resid & 503.3732 & Schwarz criterion & 5.674774 \\
Log likelihood & -98.56242 & Hannan-Quinn criter. & 5.617506 \\
F-statistic & 13.99160 & Durbin-Watson stat & 2.356323 \\
Prob(F-statistic) & 0.000677 & & \\
\hline \hline
\end{tabular}




\section{Appendix G: Omitted Variable Test}

Omitted Variables Test

Equation: UNTITLED

Specification: DUR C GINI RIR IR

Instrument specification: GINI TL UPOP

Omitted Variables: RIR IR

\begin{tabular}{lccc}
\hline \hline & Value & df & Probability \\
\cline { 2 - 4 } Difference in J-stats & 2.413994 & 2 & 0.2991 \\
\hline \hline J-statistic summary: & \multicolumn{2}{l}{} \\
& Value & \\
\cline { 2 - 3 } Restricted J-statistic & 2.413994 & \\
Unrestricted J-statistic & $2.00 \mathrm{E}-38$ & \\
\hline \hline
\end{tabular}

Restricted Test Equation:

Dependent Variable: DUR

Method: Two-Stage Least Squares

Date: 03/31/13 Time: 18:43

Sample: 136

Included observations: 36

Instrument specification: GINI TL UPOP

Constant added to instrument list

\begin{tabular}{lrlrr}
\hline \hline \multicolumn{1}{c}{ Variable } & Coefficient & Std. Error & t-Statistic & Prob. \\
\hline \multicolumn{1}{c}{ C } & 0.532345 & 0.312985 & 1.700864 & 0.0981 \\
\multicolumn{1}{c}{ GINI } & 0.017793 & 0.007595 & 2.342721 & 0.0251 \\
\hline \hline R-squared & 0.138986 & Mean dependent var & 1.248056 \\
Adjusted R-squared & 0.113662 & S.D. dependent var & 0.433509 \\
S.E. of regression & 0.408130 & Sum squared resid & 5.663372 \\
F-statistic & 5.488341 & Durbin-Watson stat & 2.188950 \\
Prob(F-statistic) & 0.025134 & Second-Stage SSR & 5.663372 \\
J-statistic & 2.413994 & Instrument rank & 4 \\
Prob(J-statistic) & 0.299094 & & \\
\hline \hline
\end{tabular}


Omitted Variables Test

Equation: UNTITLED

Specification: AMP C GINI RIR IR

Instrument specification: GINI TL UPOP

Omitted Variables: RIR IR

\begin{tabular}{lccc}
\hline \hline & Value & df & Probability \\
\cline { 2 - 3 } Difference in J-stats & 5.777965 & 2 & 0.0556 \\
\hline \hline J-statistic summary: & \multicolumn{2}{|}{} \\
& Value & \\
\cline { 2 - 3 } Restricted J-statistic & 5.777965 & \\
Unrestricted J-statistic & $2.80 \mathrm{E}-37$ & \\
\hline \hline
\end{tabular}

Restricted Test Equation:

Dependent Variable: AMP

Method: Two-Stage Least Squares

Date: 03/31/13 Time: 18:54

Sample: 136

Included observations: 36

Instrument specification: GINI TL UPOP

Constant added to instrument list

\begin{tabular}{lrlrr}
\hline \hline \multicolumn{1}{c}{ Variable } & Coefficient & \multicolumn{1}{c}{ Std. Error } & t-Statistic & Prob. \\
\hline \hline \multicolumn{1}{c}{ CINI } & -5.992143 & 2.950741 & -2.030725 & 0.0502 \\
\multicolumn{1}{c}{ GIN } & 0.267830 & 0.071602 & 3.740535 & 0.0007 \\
\hline \hline R-squared & 0.291543 & Mean dependent var & 4.781389 \\
Adjusted R-squared & 0.270706 & S.D. dependent var & 4.505616 \\
S.E. of regression & 3.847739 & Sum squared resid & 503.3732 \\
F-statistic & 13.99160 & Durbin-Watson stat & 2.356323 \\
Prob(F-statistic) & 0.000677 & Second-Stage SSR & 503.3732 \\
J-statistic & 5.777965 & Instrument rank & 4 \\
Prob(J-statistic) & 0.055633 & & \\
\hline \hline
\end{tabular}


Omitted Variables Test

Equation: UNTITLED

Specification: CUM C GINI RIR IR

Instrument specification: GINI TL UPOP

Omitted Variables: RIR IR

\begin{tabular}{lccc}
\hline \hline & Value & df & Probability \\
\cline { 2 - 3 } Difference in J-stats & 4.630676 & 2 & 0.0987 \\
\hline \hline J-statistic summary: & \multicolumn{2}{|}{} \\
& Value & \\
\cline { 2 - 3 } Restricted J-statistic & 4.630676 & \\
Unrestricted J-statistic & 0.000000 & \\
\hline \hline
\end{tabular}

Restricted Test Equation:

Dependent Variable: CUM

Method: Two-Stage Least Squares

Date: 03/31/13 Time: 18:56

Sample: 136

Included observations: 36

Instrument specification: GINI TL UPOP

Constant added to instrument list

\begin{tabular}{lrlrr}
\hline \hline \multicolumn{1}{c}{ Variable } & Coefficient & \multicolumn{1}{c}{ Std. Error } & t-Statistic & Prob. \\
\hline \hline \multicolumn{1}{c}{ GINI } & -4.267513 & 3.412961 & -1.250384 & 0.2197 \\
\multicolumn{1}{c}{0.203838} & 0.082818 & 2.461277 & 0.0191 \\
\hline \hline R-squared & 0.151228 & Mean dependent var & 3.931944 \\
Adjusted R-squared & 0.126264 & S.D. dependent var & 4.761194 \\
S.E. of regression & 4.450470 & Sum squared resid & 673.4272 \\
F-statistic & 6.057884 & Durbin-Watson stat & 2.452886 \\
Prob(F-statistic) & 0.019076 & Second-Stage SSR & 673.4272 \\
J-statistic & 4.630676 & Instrument rank & 4 \\
Prob(J-statistic) & 0.098733 & & \\
\hline \hline
\end{tabular}




\section{Appendix H: Endogeneity Test Result}

Dependent Variable: DUR1

Method: Least Squares

Date: 03/31/13 Time: 13:52

Sample: 136

Included observations: 36

\begin{tabular}{lrlrl}
\hline \hline \multicolumn{1}{c}{ Variable } & Coefficient & \multicolumn{1}{c}{ Std. Error } & t-Statistic & Prob. \\
\hline \multicolumn{1}{c}{ GINI } & -0.219248 & 0.098726 & -2.220762 & 0.0333 \\
RES & 0.269485 & 0.194939 & 1.739300 & 0.1113 \\
\multicolumn{1}{c}{ C } & 14.90681 & 4.029345 & 3.699562 & 0.0008 \\
\hline \hline R-squared & 0.134058 & Mean dependent var & 6.087500 \\
Adjusted R-squared & 0.081576 & S.D. dependent var & 4.266565 \\
S.E. of regression & 4.088838 & Akaike info criterion & 5.734054 \\
Sum squared resid & 551.7137 & Schwarz criterion & 5.866014 \\
Log likelihood & -100.2130 & Hannan-Quinn criter. & 5.780112 \\
F-statistic & 2.554389 & Durbin-Watson stat & 2.093370 \\
Prob(F-statistic) & 0.093018 & & \\
\hline \hline
\end{tabular}

Dependent Variable: AMP1

Method: Least Squares

Date: 03/31/13 Time: 13:53

Sample: 136

Included observations: 36

\begin{tabular}{lrlrl}
\hline \hline \multicolumn{1}{c}{ Variable } & Coefficient & \multicolumn{1}{c}{ Std. Error } & t-Statistic & Prob. \\
\hline \multicolumn{1}{c}{ GINI } & -0.718329 & 0.519024 & -1.384001 & 0.1756 \\
RES & 1.073456 & 0.814543 & 1.317863 & 0.1966 \\
\multicolumn{1}{c}{ C } & 55.65776 & 21.18303 & 2.627469 & 0.0130 \\
\hline \hline R-squared & 0.063444 & Mean dependent var & 26.76278 \\
Adjusted R-squared & 0.006683 & S.D. dependent var & 21.56798 \\
S.E. of regression & 21.49580 & Akaike info criterion & 9.053247 \\
Sum squared resid & 15248.29 & Schwarz criterion & 9.185207 \\
Log likelihood & -159.9584 & Hannan-Quinn criter. & 9.099305 \\
F-statistic & 1.117735 & Durbin-Watson stat & 1.782474 \\
Prob(F-statistic) & 0.339085 & & \\
\hline \hline
\end{tabular}


Dependent Variable: CUM1

Method: Least Squares

Date: 03/31/13 Time: 13:55

Sample: 136

Included observations: 36

\begin{tabular}{lrlrr}
\hline \hline \multicolumn{1}{c}{ Variable } & Coefficient & \multicolumn{1}{c}{ Std. Error } & t-Statistic & Prob. \\
\hline \hline \multicolumn{1}{c}{ GINI } & 3.567547 & 1.088941 & 3.276161 & 0.0024 \\
\multicolumn{1}{c}{ RES } & -1.609877 & 7.863355 & -0.204732 & 0.8390 \\
\hline \hline R-squared & -0.036377 & Mean dependent var & 153.8906 \\
Adjusted R-squared & -0.066859 & S.D. dependent var & 258.1685 \\
S.E. of regression & 266.6593 & Akaike info criterion & 14.06377 \\
Sum squared resid & 2417644. & Schwarz criterion & 14.15175 \\
Log likelihood & -251.1479 & Hannan-Quinn criter. & 14.09448 \\
Durbin-Watson stat & 1.606052 & & \\
\hline \hline
\end{tabular}




\section{Appendix I: Omitted Variable Test}

Omitted Variables Test

Equation: UNTITLED

Specification: DUR1 GINI C

Omitted Variables: RIR IR

\begin{tabular}{lccc}
\hline \hline & Value & df & Probability \\
\cline { 2 - 4 } F-statistic & 0.597473 & $(2,32)$ & 0.5562 \\
Likelihood ratio & 1.319821 & 2 & 0.5169 \\
\hline \hline
\end{tabular}

F-test summary:

Test SSR

Restricted SSR

Unrestricted SSR

Unrestricted SSR

\begin{tabular}{ccc} 
Sum of Sq. & df & Mean Squares \\
\hline 21.68112 & 2 & 10.84056 \\
602.2902 & 34 & 17.71442 \\
580.6091 & 32 & 18.14403 \\
580.6091 & 32 & 18.14403
\end{tabular}

LR test summary:

Restricted LogL

Unrestricted LogL

\begin{tabular}{cc} 
Value & df \\
\hline-101.7918 & 34 \\
-101.1318 & 32
\end{tabular}

Unrestricted Test Equation:

Dependent Variable: DUR1

Method: Least Squares

Date: 03/31/13 Time: 17:34

Sample: 136

Included observations: 36

\begin{tabular}{lrlrl}
\hline \hline \multicolumn{1}{c}{ Variable } & Coefficient & Std. Error & t-Statistic & Prob. \\
\hline \hline \multicolumn{1}{c}{ GINI } & -0.056475 & 0.093492 & -0.604068 & 0.5501 \\
C & 8.902780 & 3.667001 & 2.427810 & 0.0210 \\
RIR & -0.038668 & 0.123127 & -0.314050 & 0.7555 \\
IR & -0.007478 & 0.011243 & -0.665117 & 0.5107 \\
\hline \hline R-squared & 0.088705 & Mean dependent var & 6.087500 \\
Adjusted R-squared & 0.003271 & S.D. dependent var & 4.266565 \\
S.E. of regression & 4.259581 & Akaike info criterion & 5.840658 \\
Sum squared resid & 580.6091 & Schwarz criterion & 6.016605 \\
Log likelihood & -101.1318 & Hannan-Quinn criter. & 5.902068 \\
F-statistic & 1.038288 & Durbin-Watson stat & 2.146817 \\
Prob(F-statistic) & 0.388870 & & \\
\hline \hline
\end{tabular}


Omitted Variables Test

Equation: UNTITLED

Specification: AMP1 GINI C

Omitted Variables: RIR IR

\begin{tabular}{lccc}
\hline \hline & Value & df & Probability \\
\cline { 2 - 4 } F-statistic & 0.717325 & $(2,32)$ & 0.4957 \\
Likelihood ratio & 1.578848 & 2 & 0.4541 \\
\hline \hline
\end{tabular}

F-test summary:

Test SSR

Restricted SSR

Unrestricted SSR

Unrestricted SSR

\begin{tabular}{ccc} 
Sum of Sq. & df & Mean Squares \\
\hline 688.7246 & 2 & 344.3623 \\
16050.79 & 34 & 472.0821 \\
15362.07 & 32 & 480.0646 \\
15362.07 & 32 & 480.0646
\end{tabular}

LR test summary:

Restricted LogL

\begin{tabular}{cc} 
Value & df \\
\hline-160.8817 & 34 \\
-160.0923 & 32
\end{tabular}

Unrestricted $\log \mathrm{L}$

Unrestricted Test Equation:

Dependent Variable: AMP1

Method: Least Squares

Date: 03/31/13 Time: 17:35

Sample: 136

Included observations: 36

\begin{tabular}{lrlrl}
\hline \hline \multicolumn{1}{c}{ Variable } & Coefficient & Std. Error & t-Statistic & Prob. \\
\hline \hline \multicolumn{1}{c}{ GINI } & 0.007109 & 0.480901 & 0.014783 & 0.9883 \\
C & 29.90859 & 18.86227 & 1.585631 & 0.1227 \\
RIR & -0.322482 & 0.633338 & -0.509178 & 0.6141 \\
IR & -0.033599 & 0.057832 & -0.580983 & 0.5653 \\
\hline \hline R-squared & 0.056455 & Mean dependent var & 26.76278 \\
Adjusted R-squared & -0.032002 & S.D. dependent var & 21.56798 \\
S.E. of regression & 21.91038 & Akaike info criterion & 9.116237 \\
Sum squared resid & 15362.07 & Schwarz criterion & 9.292183 \\
Log likelihood & -160.0923 & Hannan-Quinn criter. & 9.177647 \\
F-statistic & 0.638221 & Durbin-Watson stat & 1.835810 \\
Prob(F-statistic) & 0.595951 & & \\
\hline \hline
\end{tabular}


Omitted Variables Test

Equation: UNTITLED

Specification: CUM1 GINI C

Omitted Variables: RIR IR

\begin{tabular}{lccc}
\hline \hline & Value & df & Probability \\
\cline { 2 - 4 } F-statistic & 1.124528 & $(2,32)$ & 0.3373 \\
Likelihood ratio & 2.445232 & 2 & 0.2945 \\
\hline \hline
\end{tabular}

F-test summary:

Test SSR

Restricted SSR

Unrestricted SSR

Unrestricted SSR

\begin{tabular}{ccc} 
Sum of Sq. & df & Mean Squares \\
\hline 152190.8 & 2 & 76095.39 \\
2317590. & 34 & 68164.41 \\
2165399. & 32 & 67668.73 \\
2165399. & 32 & 67668.73
\end{tabular}

LR test summary:

Restricted LogL

\begin{tabular}{cc} 
Value & df \\
\hline-250.3871 & 34 \\
-249.1645 & 32
\end{tabular}

Unrestricted Test Equation:

Dependent Variable: CUM1

Method: Least Squares

Date: 03/31/13 Time: 17:35

Sample: 136

Included observations: 36

\begin{tabular}{lrlrr}
\hline \hline \multicolumn{1}{c}{ Variable } & Coefficient & Std. Error & t-Statistic & Prob. \\
\hline \hline \multicolumn{1}{c}{ GINI } & 0.379695 & 5.709522 & 0.066502 & 0.9474 \\
C & 199.5659 & 223.9433 & 0.891145 & 0.3795 \\
RIR & -9.819739 & 7.519341 & -1.305931 & 0.2009 \\
IR & 0.114399 & 0.686608 & 0.166615 & 0.8687 \\
\hline \hline R-squared & 0.071753 & Mean dependent var & 153.8906 \\
Adjusted R-squared & -0.015270 & S.D. dependent var & 258.1685 \\
S.E. of regression & 260.1321 & Akaike info criterion & 14.06470 \\
Sum squared resid & 2165399. & Schwarz criterion & 14.24064 \\
Log likelihood & -249.1645 & Hannan-Quinn criter. & 14.12611 \\
F-statistic & 0.824530 & Durbin-Watson stat & 1.775078 \\
Prob(F-statistic) & 0.490077 & & \\
\hline \hline
\end{tabular}


Appendix J: OLS Estimations: Expansion

Dependent Variable: DUR1

Method: Least Squares

Date: 03/14/14 Time: 21:15

Sample: 136

Included observations: 36

\begin{tabular}{lrlrr}
\hline \hline \multicolumn{1}{c}{ Variable } & Coefficient & Std. Error & t-Statistic & Prob. \\
\hline \multicolumn{1}{c}{ GINI } & 10.50551 & 3.227668 & 3.254831 & 0.0026 \\
\multicolumn{1}{c}{-0.109832} & 0.078322 & -1.402313 & 0.1699 \\
\hline \hline R-squared & 0.054675 & Mean dependent var & 6.087500 \\
Adjusted R-squared & 0.026872 & S.D. dependent var & 4.266565 \\
S.E. of regression & 4.208850 & Akaike info criterion & 5.766209 \\
Sum squared resid & 602.2902 & Schwarz criterion & 5.854182 \\
Log likelihood & -101.7918 & Hannan-Quinn criter. & 5.796914 \\
F-statistic & 1.966481 & Durbin-Watson stat & 2.200726 \\
Prob(F-statistic) & 0.169887 & & \\
\hline \hline
\end{tabular}

Dependent Variable: AMP1

Method: Least Squares

Date: 03/14/14 Time: 21:15

Sample: 136

Included observations: 36

\begin{tabular}{lrlrr}
\hline \hline \multicolumn{1}{c}{ Variable } & Coefficient & Std. Error & t-Statistic & Prob. \\
\hline \multicolumn{1}{c}{ GINI } & 38.12583 & 16.66227 & 2.288153 & 0.0285 \\
\multicolumn{1}{c}{ GI } & -0.282485 & 0.404323 & -0.698662 & 0.4895 \\
\hline \hline R-squared & 0.014154 & Mean dependent var & 26.76278 \\
Adjusted R-squared & -0.014842 & S.D. dependent var & 21.56798 \\
S.E. of regression & 21.72745 & Akaike info criterion & 9.048983 \\
Sum squared resid & 16050.79 & Schwarz criterion & 9.136956 \\
Log likelihood & -160.8817 & Hannan-Quinn criter. & 9.079688 \\
F-statistic & 0.488129 & Durbin-Watson stat & 1.880562 \\
Prob(F-statistic) & 0.489515 & & \\
\hline \hline
\end{tabular}


Dependent Variable: CUM1

Method: Least Squares

Date: 03/14/14 Time: 21:11

Sample: 136

Included observations: 36

\begin{tabular}{lrlrr}
\hline \hline \multicolumn{1}{c}{ Variable } & Coefficient & Std. Error & t-Statistic & Prob. \\
\hline \multicolumn{1}{c}{ GINI } & 246.1593 & 200.2185 & 1.229453 & 0.2273 \\
\multicolumn{1}{c}{ GIN } & -2.293800 & 4.858459 & -0.472125 & 0.6399 \\
\hline \hline R-squared & 0.006513 & Mean dependent var & 153.8906 \\
Adjusted R-squared & -0.022707 & S.D. dependent var & 258.1685 \\
S.E. of regression & 261.0832 & Akaike info criterion & 14.02151 \\
Sum squared resid & 2317590. & Schwarz criterion & 14.10948 \\
Log likelihood & -250.3871 & Hannan-Quinn criter. & 14.05221 \\
F-statistic & 0.222902 & Durbin-Watson stat & 1.682888 \\
Prob(F-statistic) & 0.639854 & & \\
\hline \hline
\end{tabular}

